Prepared in cooperation with the

Pomperaug River Watershed Coalition and the Town of Woodbury, Connecticut

\title{
Estimation of the Effects of Land Use and Groundwater Withdrawals on Streamflow for the Pomperaug River, Connecticut
}

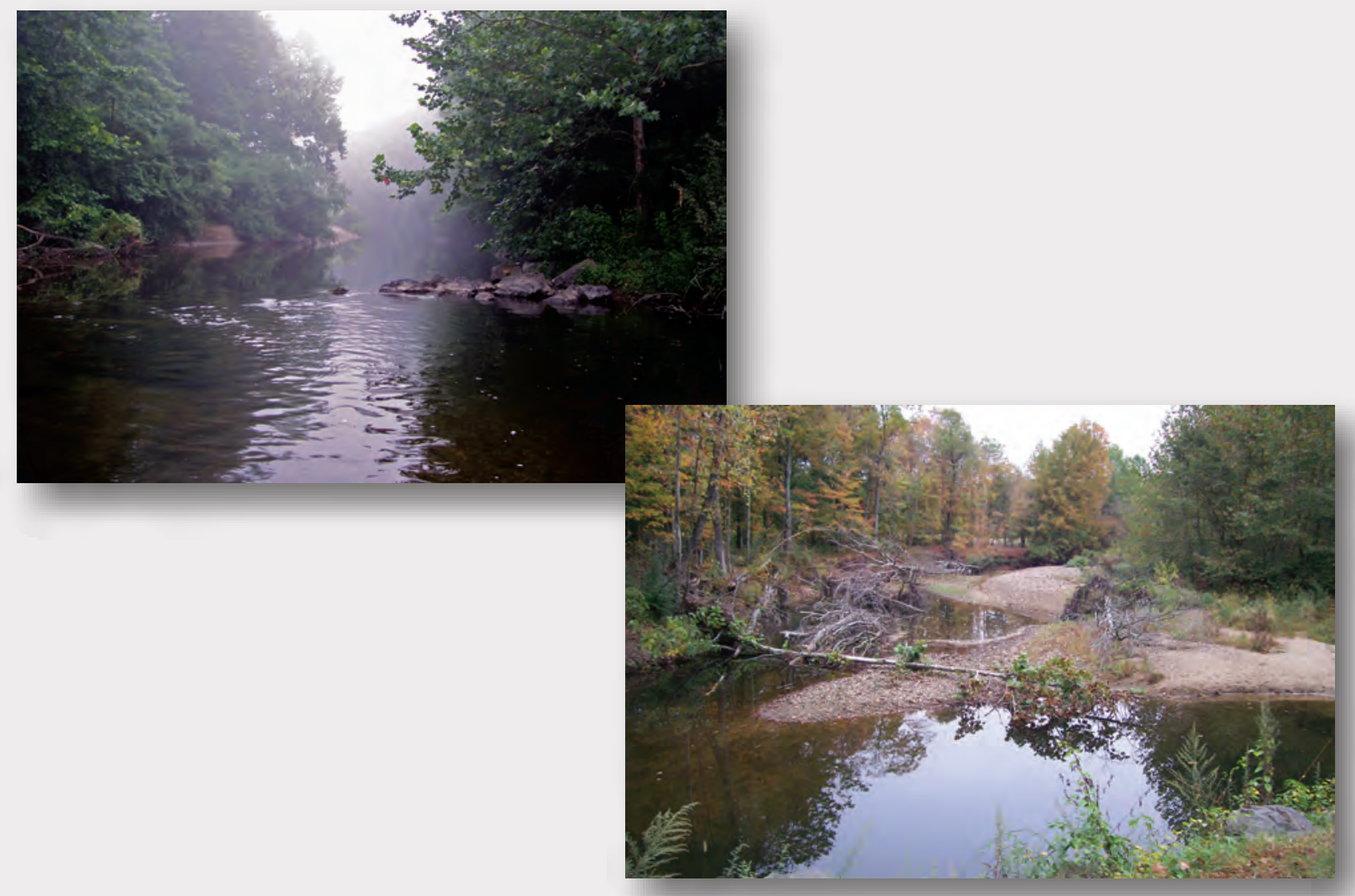

Scientific Investigations Report 2010-5114 
Cover. Photographs show views of the Pomperaug River in Southbury, Connecticut. (Photographs by Edward Edelson, Pomperaug River Watershed Coalition) 


\section{Estimation of the Effects of Land Use and Groundwater Withdrawals on Streamflow for the Pomperaug River, Connecticut}

By David M. Bjerklie, J. Jeffrey Starn, and Claudia Tamayo

Prepared in cooperation with the

Pomperaug River Watershed Coalition and the Town of Woodbury, Connecticut

Scientific Investigations Report 2010-5114 


\section{U.S. Department of the Interior \\ KEN SALAZAR, Secretary \\ U.S. Geological Survey \\ Marcia K. McNutt, Director}

U.S. Geological Survey, Reston, Virginia: 2010

For more information on the USGS - the Federal source for science about the Earth, its natural and living resources, natural hazards, and the environment, visit http://www.usgs.gov or call 1-888-ASK-USGS

For an overview of USGS information products, including maps, imagery, and publications, visit http://www.usgs.gov/pubprod

To order this and other USGS information products, visit http://store.usgs.gov

Any use of trade, product, or firm names is for descriptive purposes only and does not imply endorsement by the U.S. Government.

Although this report is in the public domain, permission must be secured from the individual copyright owners to reproduce any copyrighted materials contained within this report.

Suggested citation:

Bjerklie, D.M., Starn, J.J., and Tamayo, Claudia, 2010, Estimation of the effects of land use and groundwater withdrawals on streamflow for the Pomperaug River, Connecticut: U.S. Geological Survey Scientific Investigations Report 2010-5114, 81 p., at http://pubs.usgs.gov/sir/2010/5114. 


\section{Contents}

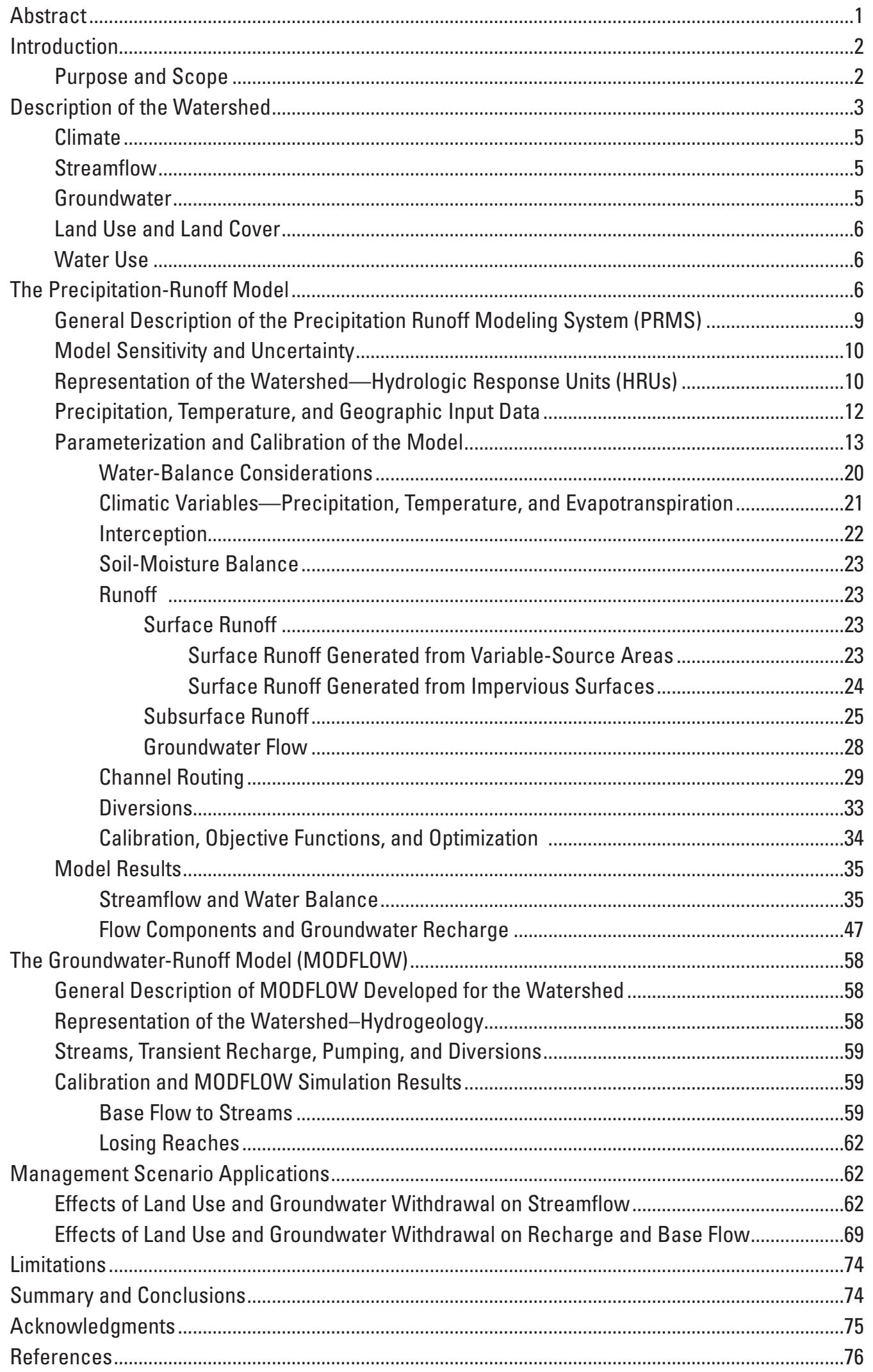




\section{Figures}

1. Map showing location of the Pomperaug River watershed, Connecticut, showing weather stations and U.S. Geological Survey streamgages used in the study .....

2. Map showing the Pomperaug River watershed, Connecticut, showing town boundaries, watershed boundaries of the two main tributaries (Weekeepeemee and Nonnewaug Rivers), streamgages, and location of coarse glacial stratified drift deposits in the watershed.

3. Map showing the Pomperaug River watershed, Connecticut, showing hydrographic features and hydrologic response unit boundaries.

4. Bar graph showing annual precipitation totals for water years 1976 to 2005 spatially averaged from 12 surrounding National Weather Service coop stations

5. Maps showing $(A)$ topographic relief (slope) of the watershed and $(B)$ the mean topographic slope for each hydrologic response unit used in the Precipitation Runoff Modeling System model of the Pomperaug River watershed, Connecticut.

6. Maps showing $(A)$ distribution of coarse glacial stratified deposits in the watershed and $(B)$ the fraction of coarse glacial stratified deposits in each hydrologic response unit used in the Precipitation Runoff Modeling System model of the Pomperaug River watershed, Connecticut.

7. Maps showing $(A)$ the drainage network (stream and rivers) in the watershed and $(B)$ the drainage density of each hydrologic response unit used in the Precipitation Runoff Modeling System model of the Pomperaug River watershed, Connecticut........16

8. Maps showing $(A)$ distribution of Class $D$ soils in the watershed and $(B)$ the fraction of Class D soils in each hydrologic response unit used in the Precipitation Runoff Modeling System model of the Pomperaug River watershed, Connecticut.

9. Maps showing $(A)$ land use and land cover in the watershed and $(B)$ the percent impervious surface in each hydrologic response unit in the Pomperaug River watershed, Connecticut.

10. Maps showing land-cover density (tree canopy) class for each hydrologic response unit in the $(A)$ summer and $(B)$ winter as used in the Precipitation Runoff Modeling System model of the Pomperaug River watershed, Connecticut.

11. Hydrograph showing relation between potential evapotranspiration (PET) estimated from the Precipitation Runoff Modeling System and by the Northeast Regional Climate Center and averaged for four weather stations reporting hourly for the period January 1, 1999, to April 30, 2003, near the Pomperaug River watershed, Connecticut 22

12. Graph showing relation between total impervious area in the watershed [as mapped by Prisloe and others (2002)] and effective impervious area as used in the Precipitation Runoff Modeling System model for three different data sets, Pomperaug River watershed, Connecticut

13. Hydrograph showing the continuous response (in minutes) of flow events in the Nonnewaug, Weekeepeemee, and Pomperaug Rivers streamgages, Connecticut, March 1 to 7, 2004

14. Hydrograph of stage for the Pomperaug, Weekeepeemee, and Nonnewaug Rivers, Connecticut, during the flood event of March 29, 2005, showing the effect of storage at the Pomperaug streamgage.

15. Aerial map showing location of three abandoned quarry ponds and their proximity to the Pomperaug River, Connecticut.

16. Photograph looking south (downstream) of the high-flow event of March 29, 2005, showing the Pomperaug River, Connecticut, on the extreme left, and overflow into the quarry pond connector stream on the right 
17. Bar graph showing simulated and observed annual mean streamflow for the Pomperaug River at Southbury, Connecticut, for water years 1999 through 2005 ..........36

18. Hydrograph showing simulated and observed monthly mean streamflows for the Pomperaug River at Southbury, Connecticut, for calendar years 1998 through 2005.....37

19. Hydrographs showing simulated and observed daily streamflow for the (A) Pomperaug (B) Nonnewaug and (C) Weekeepeemee Rivers, Connecticut.

20. Scatterplots showing log residual probability and quartile distribution plots, showing the fit line if the residuals are normally distributed, for the daily residuals ( $A$ and $B$ ) and the monthly residuals ( $C$ and $D)$, Pomperaug, Weekeepeemee, and Nonnewaug Rivers, Connecticut

21. Graphs showing simulated and observed flow-duration curves for the (A) Pomperaug

(B) Nonnewaug and (C) Weekeepeemee Rivers, Connecticut.

22. Scatterplot showing relation between the percentage of coarse glacial stratified deposits and the simulated average annual recharge in each hydrologic response unit, Pomperaug River watershed, Connecticut.

23. Maps showing simulated spatially distributed monthly mean recharge (inches) for each hydrologic response unit in the Pomperaug River watershed, Connecticut.

24. Maps showing simulated spatially distributed monthly mean subsurface runoff (inches) for each hydrologic response unit in the Pomperaug River watershed, Connecticut.

25. Maps showing simulated spatially distributed monthly mean surface runoff (inches) for each hydrologic response unit in the Pomperaug River watershed, Connecticut....56

26. Daily hydrographs of the streamflow in the Pomperaug River at the Southbury streamgage for the period 1999 to 2005 derived by combining the MODFLOW-derived base flow with PRMS-derived subsurface and surface-runoff components showing $(A)$ the PRMS + MODFLOW hydrograph and the observed flow, and (B) the PRMS + MODFLOW hydrograph and the PRMS only hydrograph.

27. Daily base-flow hydrograph for South Brook near its confluence with the Pomperaug River, Connecticut, showing several periods of no flow in the stream (dry streambed).

28. Maps showing impervious surface in the Pomperaug River watershed, Connecticut, as a percentage of each hydrologic response unit determined on the basis of land-use type for $(A)$ current (2002) conditions, and (B) projected full build-out impervious surface.

29. Bar graphs showing simulated daily average runoff in the Pomperaug River, Connecticut, as a function of hypothetical land-use change, $(A)$ total streamflow, in inches; $(B)$ percentage of total runoff that is groundwater and surface runoff; and $(C)$ runoff by source (groundwater, subsurface, and surface), in inches

30. Graph showing probability of daily flow rate exceeded in the Pomperaug River at Southbury on any given day as a function of hypothetical land-use scenario in the watershed

31. Scatterplots showing change in groundwater runoff, subsurface runoff, and surface runoff as a function of change in effective impervious surface for the two full build-out scenarios with $(A)$ maximum and $(B)$ minimum stormwater collection relative to existing conditions for the Pomperaug River at Southbury, Connecticut.

32. Bar graphs showing average percentage change in $(A)$ recharge and $(B)$ surface runoff relative to existing conditions by hydrologic response unit, Pomperaug River watershed, Connecticut, for the full build-out scenarios, with maximum and minimum stormwater collection. 
33. Scatterplots showing percentage change in streamflow as a function of simulated streamflow for full build-out scenarios with $(A)$ maximum and $(B)$ minimum stormwater collection relative to existing conditions for the Pomperaug River at Southbury,

Connecticut. 70

34. Boxplots showing average monthly groundwater recharge for uplands and valleys for $(A)$ all-forest and $(B)$ all-grass scenarios, Pomperaug River watershed, Connecticut ..72

35. Hydrograph showing effect of projected increases in pumping on base flow assuming full build-out land use, Pomperaug River watershed, Connecticut 73

\section{Tables}

1. Groundwater-use data for the Pomperaug River watershed, Connecticut.

2. Registered and permitted water diversions in the Pomperaug River watershed, Connecticut.

3. Data and parameter requirements for the Precipitation Runoff Modeling System (PRMS) model.

4. Impervious-surface data used for Connecticut runoff analysis.

5. Simulated and observed annual mean streamflow for the Pomperaug River at Southbury, Connecticut, for water years 1999 through 2005

6. Daily and monthly streamflow statistics for the Pomperaug River at Southbury, Connecticut

7. Daily and monthly streamflow statistics for the Weekeepeemee and Nonnewaug Rivers, Connecticut

8. Simulated and observed streamflow percentiles for the Pomperaug, Weekeepeemee, and Nonnewaug Rivers, Connecticut, October 1, 1998, to September 30, 2005.

9. Tributary flow-ratio statistics for the Pomperaug, Weekeepeemee, and Nonnewaug Rivers, Connecticut

10. Simulated flow component contribution to the Pomperaug, Weekeepeemee, and Nonnewaug Rivers, Connecticut, at their respective gages..

11. Simulated and observed annual mean base flow estimated using PART

12. Daily and monthly base-flow statistics and recession characteristics for the Pomperaug River, Connecticut.

13. Estimated average annual recharge in the Pomperaug River watershed, Connecticut

14. Simulated runoff data for South Brook (three hydrologic response units), Connecticut, July 1-11, 2004

15. Wells and pumping rates used in the MODFLOW-2000 model in the Pomperaug River watershed, Connecticut.

16. Simulated streamflow percentiles for different impervious scenarios in the Pomperaug, Weekeepeemee, and Nonnewaug Rivers, Connecticut 66

17. Regression statistics for multiple linear regression of physical attributes to predict recharge for the Pomperaug River watershed, Connecticut.

18. Percentage of stream reaches in the Pomperaug River watershed, Connecticut, that can lose water to the groundwater, gain water from the groundwater, or can go dry for the full build-out scenarios compared to the existing scenario

A1. GIS data and supporting parameter information for each HRU 


\section{Conversion Factors and Datum}

Inch/Pound to SI

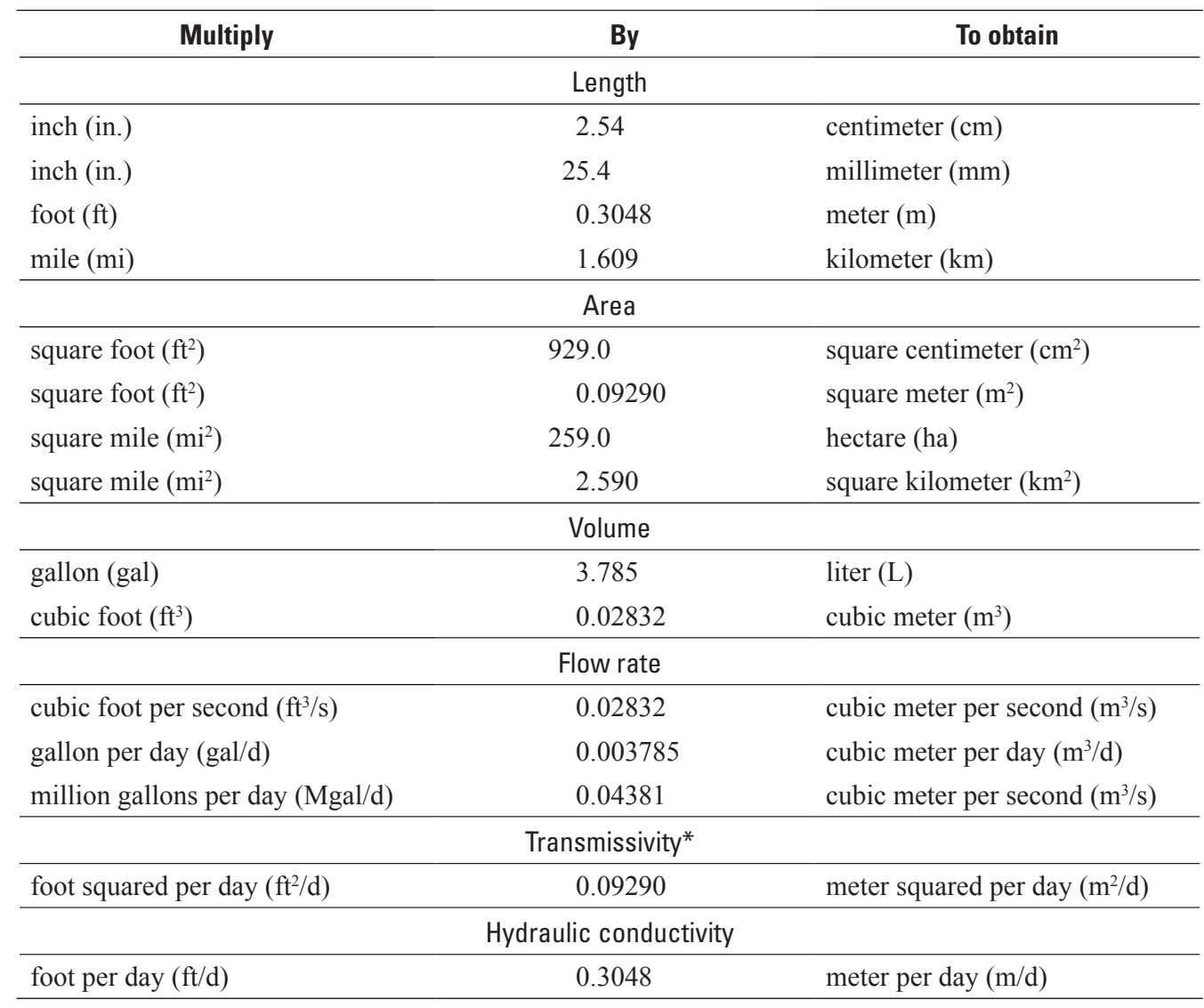

Temperature in degrees Fahrenheit $\left({ }^{\circ} \mathrm{F}\right)$ may be converted to degrees Celsius $\left({ }^{\circ} \mathrm{C}\right)$ as follows:

$$
{ }^{\circ} \mathrm{C}=\left({ }^{\circ} \mathrm{F}-32\right) / 1.8
$$

Vertical coordinate information is referred to as elevation (above a standard vertical datum) and referenced to the National Geodetic Vertical Datum of 1929 (NGVD 29).

Horizontal coordinate information is referenced to the North American Datum of 1983 (NAD 83).

*Transmissivity: The standard unit for transmissivity is cubic foot per day per square foot times foot of aquifer thickness [(ft $\left./ \mathrm{d}) / \mathrm{ft}^{2}\right] \mathrm{ft}$. In this report, the mathematically reduced form, foot squared per day $\left(\mathrm{ft}^{2} / \mathrm{d}\right)$, is used for convenience. 
THIS PAGE INTENTIONALLY LEFT BLANK 


\title{
Estimation of the Effects of Land Use and Groundwater Withdrawals on Streamflow for the Pomperaug River, Connecticut
}

\author{
By David M. Bjerklie, J. Jeffrey Starn, and Claudia Tamayo
}

\section{Abstract}

A precipitation runoff model for the Pomperaug River watershed, Connecticut was developed to address issues of concern including the effect of development on streamflow and groundwater recharge, and the implications of water withdrawals on streamflow. The model was parameterized using a strategy that requires a minimum of calibration and optimization by establishing basic relations between the parameter value and physical characteristics of individual hydrologic response units (HRUs) that comprise the model. The strategy was devised so that the information needed can be obtained from Geographic Information System and other general databases for Connecticut. Simulation of groundwater recharge enabled evaluation of the temporal and spatial mapping of recharge variation across the watershed and the spatial effects of changes in land cover on base flow and surface runoff.

The modeling indicated that over the course of a year, groundwater provides between 60 and 70 percent of flow in the Pomperaug River; the remainder is generated by more rapid flow through the shallow subsurface and runoff from impermeable surfaces and saturated ground. Groundwater is recharged primarily during periods of low evapotranspiration in the winter, spring, and fall. The largest amount of recharge occurs in the spring in response to snowmelt. During floods, the Weekeepeemee and Nonnewaug Rivers (tributaries that form the Pomperaug River) respond rapidly with little flood peak attenuation due to flood-plain storage. In the Pomperaug River, flood-plain storage is more important in attenuating floods; abandoned quarry ponds (O\&G ponds) adjacent to the river provide substantial flood storage above specific river stages when flow from the river spills over the banks and fills the ponds. Discharge from the ponds also helps to sustain low flows in the Pomperaug River. Similarly, releases from the Bronson-Lockwood reservoir sustain flow in the Nonnewaug River and tend to offset the effect of groundwater withdrawals from a well field adjacent to the river during periods of natural low flow.
The model indicated that under the current zoning, future development could reduce low flows by as much as 10 percent at the 99 percent exceedance level (99 percent of flows are greater than or equal to this flow), but would not substantially increase the highest flows. Simulation of projected and hypothetical development in the watershed shows, depending on how stormwater is managed, that between 10 and 20 percent effective impervious area in an HRU results in streamflow becoming dominated by the surface-runoff component. This shift from a groundwater-dominated system would likely result in substantial changes in water quality and instream habitat characteristics of the river.

Base flow to streams in the Pomperaug River watershed is reduced by both increased impervious surface and increased groundwater withdrawals. For the watershed as a whole, increasing groundwater withdrawals have the potential for causing greater overall reductions in flow compared to increased development and impervious surfaces. Additionally, on the basis of groundwater-modeling simulations, the projected increase in development across the watershed and, to a lesser extent the increase in groundwater withdrawals, will increase the number of local losing reaches experiencing dry conditions and the duration of these dry periods. The location of the losing reaches tends to be in areas near the transition from the uplands to the valley bottoms that are filled with coarse glacial stratified deposits. The simulated increase in the duration and extent of localized dry stream reaches is most sensitive to local increase in impervious surface.

Conversion of land from forest or developed land cover to pasture or agricultural land increases groundwater recharge and discharge to streams, while at the same time increasing overall streamflow (the opposite effect as increased impervious surface). These results indicate that preservation of agricultural land and pasture can provide hydrologic benefit with regard to recharge potential. If all registered diversions are used during periods of low flow, there is a risk that portions of the river system will experience extreme low flows below tolerable levels or possibly dry streambeds. 


\section{Introduction}

In recent years, increased use of surface-water and groundwater supplies in the Pomperaug River watershed in Connecticut has created concern among resource managers that future development will result in streamflows insufficient for aquatic habitat and recreational use. In response to the concern, the Pomperaug River Watershed Coalition (PRWC) was formed, and stakeholders in the watershed identified a need to determine the amount of water available for future allocation while protecting the ecological integrity of the watershed. Although the watershed is rural, the population increased by 15 percent between 1990 and 2000 as a result of suburban sprawl (Pomperaug River Watershed Coalition, Inc., 2001). Increases in population and development can lead to changes in land use and land cover that cause changes in the distribution of runoff and groundwater recharge. Unless these effects are considered when allocating the water resources, instream flow losses and degradation of water quality and ecosystems can occur. Because of uncertainty about the quantity of water available for future use, the effects of new applications for water diversion are poorly understood.

The future health and economic welfare of the communities within the watershed depend on a continuing supply of uncontaminated freshwater. Many existing sources of water are being stressed by increasing withdrawals, diversions, and demands for instream flow. More comprehensive water-use data and analysis of water-use information are needed to quantify the stress on existing supplies and to better model and evaluate possible demand-management options to supplement the traditional supply approaches. Improved watershed characterization and flow-system definition and simulation also are needed to manage aquifers and streams that serve as important local or regional sources of water supply and to manage and support watershed ecosystems. Because aquifers and streams commonly are highly interdependent, improved tools for simulating interactions between groundwater and surface water that account quantitatively for effects of withdrawals and climate variations also are needed so that watersheds can be managed more readily as systems. Hydrologic systems models capable of showing the consequences of various decisions over a wide range of hydrologic and climatic conditions will be helpful to local water managers.

The U.S. Geological Survey (USGS), in cooperation with the Town of Woodbury and the PRWC, developed a watershed model for the Pomperaug River as part of a study to evaluate the potential effects of land-use changes and watermanagement strategies on streamflow, instream habitat, and groundwater availability. The study goals are stated below:

- Characterize and develop an understanding of natural and anthropogenic influences on the groundwater and surface-water processes in the watershed.
- Develop a model parameter framework representative of hydrogeologic conditions in Connecticut and transferable to other watersheds in the State.

- Evaluate the effects of specific land-use and waterresource management scenarios on streamflow in the Pomperaug River through the development and application of a simulation model that is based on available data and could be transferable to other watersheds.

In addition, the instream-flow information from the model was used to assess habitat suitability (Parasiewicz and others, 2007) and the recharge simulated by the model was used as input to a groundwater-flow model that was developed for the watershed (Starn and Brown, 2007) in order to evaluate groundwater/surface-water interactions in the watershed and the effects of land use and water management on the availability of groundwater.

This study will benefit the municipalities and state agencies charged with managing water resources to maximize the economic benefits of a sustainable water supply while minimizing the environmental consequences of withdrawing water from the watershed. Data collected as part of this study could have other uses, for example to develop statistical methods for estimating flow characteristics for streams in Connecticut. Additionally, the information and model results presented in this report will assist the PRWC and the Connecticut Department of Environmental Protection (DEP) in understanding the effects of land-use and water-use change on habitat stress in the Pomperaug River (Parasiewicz and others, 2007).

\section{Purpose and Scope}

This report presents the results of the study to assess and model the naturally occurring surface-water and groundwater resources and an analysis of the current and possible future cumulative effects of land-use changes and withdrawals on the available streamflow in the Pomperaug River. The report describes the Precipitation Runoff Modeling System (PRMS) watershed model (Leavesley and others, 1996) used for the study and presents the strategy developed to determine objectively the appropriate parameters for the model. This strategy relies on readily available data (in a Geographic Information System (GIS)) for physical parameters such as geology, land cover, soil characteristics, and precipitation. The study area discussed in this report is the Pomperaug River basin. This report complements another report discussing a groundwaterflow model of a subarea of the basin (Starn and Brown, 2007). Recharge estimates derived from the PRMS model were used in the groundwater model and base flows calculated in the groundwater model were used to calibrate the PRMS model. 


\section{Description of the Watershed}

The Pomperaug River watershed is in western Connecticut (fig. 1) and covers an area of about $75 \mathrm{mi}^{2}$ above the streamgage at Southbury (USGS station 01204000, fig. 2). The watershed covers $91.7 \mathrm{mi}^{2}$ above its mouth where it flows into the Housatonic River (Pomperaug River Watershed Coalition, 2001). Major subwatersheds include the Weekeepeemee and Nonnewaug Rivers. (Nonnewaug is the spelling preferred by the PRWC, and used in this report; however, Nonewaug is the spelling on USGS topographic maps and in the USGS National Water Information System.) The Weekeepeemee and Nonnewaug Rivers combine to form the Pomperaug River. The Weekeepeemee watershed at its gage (USGS station 01203805 located at the confluence with the Nonnewaug River) has a watershed area of $26.8 \mathrm{mi}^{2}$. The Nonnewaug River at its streamgage (USGS station 01203600 located upstream of the confluence with the Weekeepeemee
River) has a watershed area of $17.7 \mathrm{mi}^{2}$ and a watershed area of $27 \mathrm{mi}^{2}$ at the confluence with the Weekeepeemee River.

The Pomperaug River watershed also supports major areas of groundwater withdrawal from production wells completed in glacial stratified deposits. Analysis of the available streamflow, groundwater, and climatological data and review of the literature (Meinzer and Stearns, 1929; Wilson and others, 1974; Mazzaferro, 1986a, 1986b; Grady and Weaver, 1988; Starn and others, 2000; Pomperaug River Watershed Coalition, 2001; Lyford and others, 2007) pertaining to the hydrology of the Pomperaug River watershed provide a general description and quantification of the hydrologic processes in the watershed. Portions of eight towns including Southbury, Woodbury, Bethlehem, Roxbury, Morris, Washington, Watertown, and Middlebury are located within the watershed boundaries, and water is exported out of the watershed to portions of Watertown and Oxford that are not within the watershed boundaries (fig. 2).

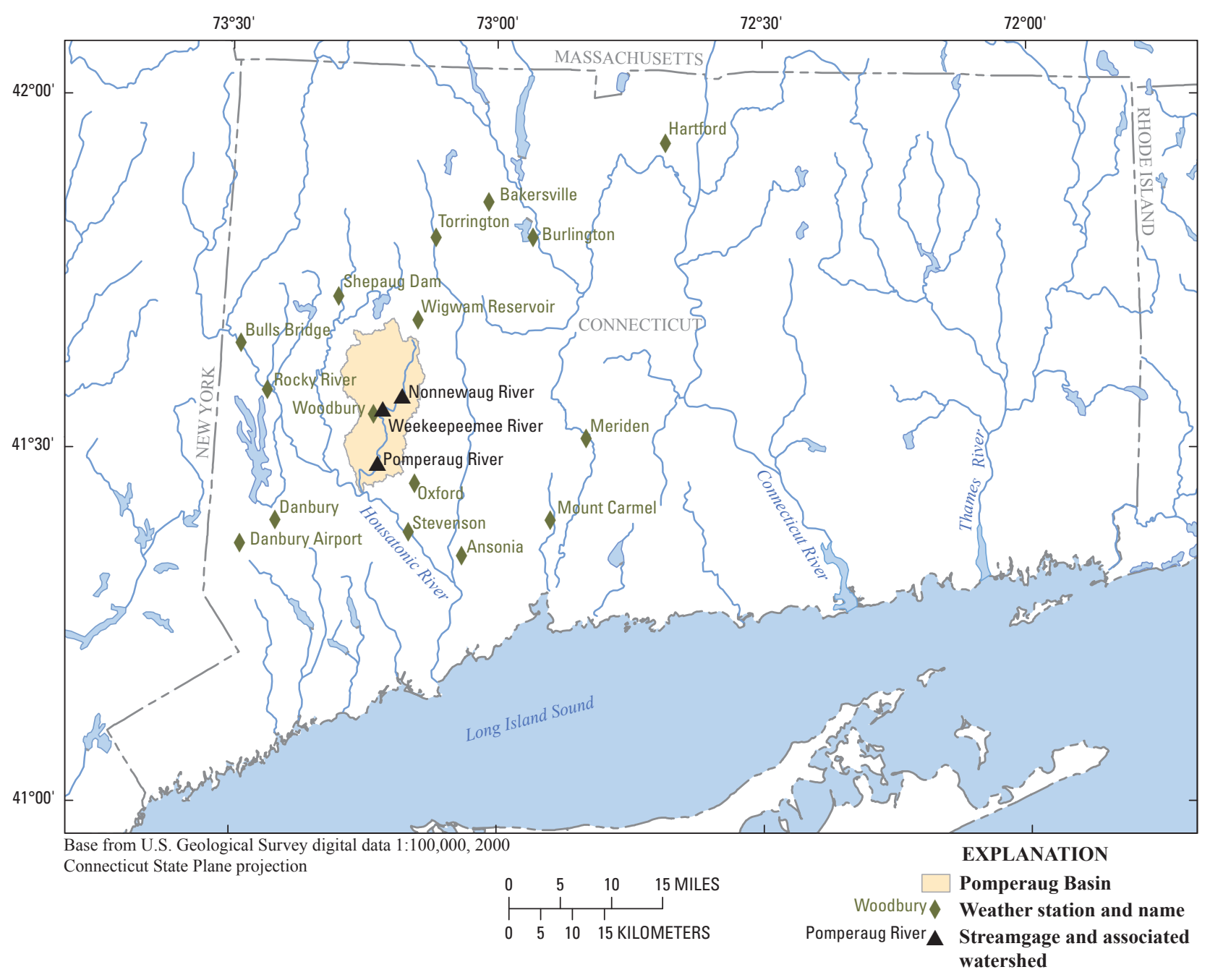

Figure 1. Location of the Pomperaug River watershed, Connecticut, showing weather stations and U.S. Geological Survey streamgages used in the study. 


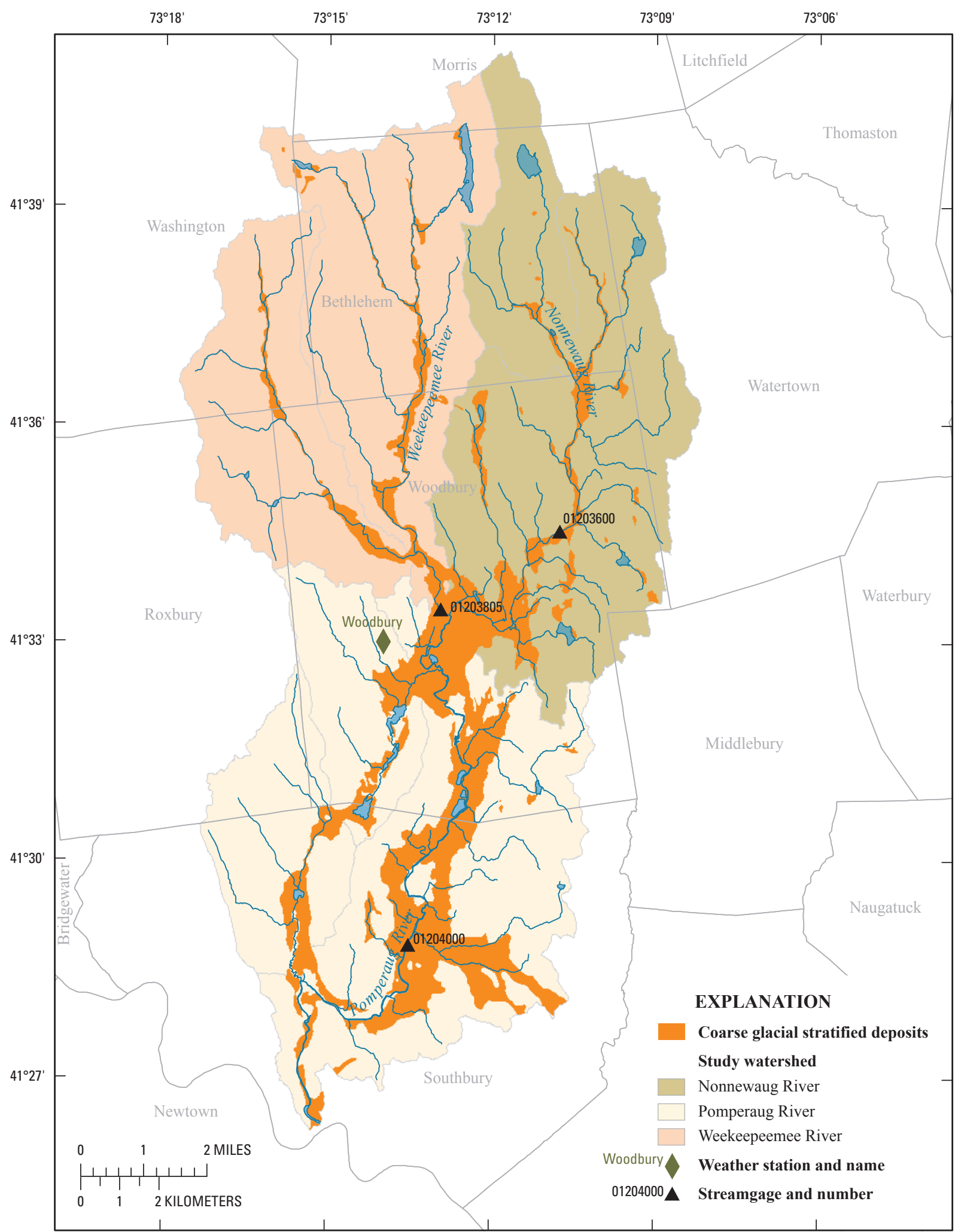

Base from U.S. Geological Survey, 1:24,000, 1969 to 1984

Connecticut State Plane projection

Figure 2. The Pomperaug River watershed, Connecticut, showing town boundaries, watershed boundaries of the two main tributaries (Weekeepeemee and Nonnewaug Rivers), streamgages, and location of coarse glacial stratified drift deposits in the watershed. 


\section{Climate}

Precipitation in the watershed is generated from regional frontal systems, more localized thunderstorms, and cyclonic systems that can produce large events resulting in floods. Precipitation in the area varies with location and generally increases with increasing elevations.

Mean precipitation in the Pomperaug River watershed, on the basis of 38 years of record, was reported by Meinzer and Stearns (1929) to be 48.8 in. per year; for 1931-1960, the mean annual precipitation was reported as 47 in. (Wilson and others, 1974); and more recent data (1966-1999) from the National Oceanic and Atmospheric National Weather Service (NOAA_NWS) Woodbury coop weather station indicates an average annual precipitation of 50.6 in. (Pomperaug River Watershed Coalition, 2001). The precipitation totals are a function of the location and period of record, but mean annual precipitation for the watershed is in the range 47 to $50 \mathrm{in}$. The annual totals have ranged historically from less than $40 \mathrm{in}$. to greater than 60 in. The amount of snow varies considerably from year to year and averages around 30 to 40 in. per year ( 3 to $4 \mathrm{in}$. of water equivalent depending on density of the snow) (Miller and others, 2002). Precipitation is generally evenly distributed throughout the year and varies spatially across the watershed depending on elevation and local topography as well as in response to the more or less random distribution of isolated storm cells.

Mean annual air temperature for the region varies from 45 to $50^{\circ} \mathrm{F}$ depending on elevation and location. Generally, temperature decreases with increasing elevation. The highest temperatures typically occur in July and August, and the lowest temperatures in January and February. Potential evapotranspiration (PET) is driven by cloud cover and solar radiation, wind speed, humidity, and air temperature. PET is highest in the summer months because of the high solar radiation and temperature, and may often be negligible during the winter months. Actual evapotranspiration (AET) is a function of PET, ground cover/vegetation, and soil moisture; therefore, even when PET is high (for example in July), AET may be small if soil moisture is low. Because of its dependence on PET, ground cover, and soil moisture, AET varies topographically and spatially throughout the watershed.

On the basis of an estimated annual precipitation of 47 to $50 \mathrm{in}$. and an annual runoff of 23 to $24 \mathrm{in}$. (Wilson and others, 1974), the long-term average annual AET for the watershed is estimated to range between 23 and 27 in., or approximately 49 to 54 percent of the annual precipitation; the remainder is mostly runoff. Wilson and others (1974) estimated AET for the Pomperaug River watershed to be on the order of 50 percent of the mean annual precipitation.

\section{Streamflow}

The Pomperaug River is formed at the confluence of its two major tributaries, the Weekeepeemee and the Nonnewaug Rivers (fig. 2). Streamflow in the Pomperaug River at Southbury (USGS Station 01204000, fig. 2) averaged $130 \mathrm{ft}^{3} / \mathrm{s}$ for the period 1933 to 2002 . This flow was equivalent to 23.4 in. of runoff annually from the watershed upstream from the streamgage. The highest monthly streamflow typically occurs in March, and the lowest in July, August, or September. The annual peak flow can occur during any month and is generally associated with rain and snowmelt events or floods associated with hurricane systems.

\section{Groundwater}

Several estimates of the groundwater contribution to streamflow have been made for the watershed. Meinzer and Stearns (1929) estimated that 40 to 50 percent of the total annual streamflow in the Pomperaug River at the Southbury streamgage originates as groundwater base flow. This estimate was based on a subjective base-flow separation technique applied by hand to the streamflow hydrograph. At the time this estimate was made, most of the watershed was cleared for agriculture, which likely affected the amount of groundwater recharge and discharge in the watershed. More recently, base flow was estimated to be between 60 and 70 percent of the annual flow (depending on storage assumptions) using an automated base-flow separation program (Rutledge, 1993; Rutledge, 1998).

The watershed contains two general aquifer types, defined on the basis of the underlying geologic materials as they relate to well yield. These two types of aquifers include an aquifer comprised of coarse glacial stratified deposits and one comprised of till and bedrock. The till and bedrock aquifer system is complex and may include a range of hydraulic conditions; however, in general, it includes at least an order of magnitude lower hydraulic conductivity and storativity than the coarse glacial stratified deposits (Lyford and others, 2007). The coarse glacial stratified aquifer supplies groundwater to domestic and production wells of varying capacity. The till and bedrock aquifer supplies groundwater primarily to individual domestic wells.

The coarse glacial stratified deposits are located in the valley bottom of the Pomperaug River and its two main tributaries, principally in the Pomperaug and Nonnewaug River Valleys (fig. 2) and range in thickness from several feet to as much as $150 \mathrm{ft}$ (Lyford and others, 2007). These deposits comprise approximately 13 percent of the watershed area. Those areas of the watershed not classified as coarse glacial stratified deposits are assumed to contain the till and bedrock aquifer. The thickness of this aquifer is defined by the depth to which groundwater yield is sufficient for an individual domestic well and is assumed be on the order of $350 \mathrm{ft}$ (Lyford and others, 2007). 


\section{Land Use and Land Cover}

Land use in the watershed has changed over the last century, from being primarily agricultural to primarily forested, and the percentage of urban and residential land use has increased over the last 30 years. The current land-use and land-cover data used in this study are based on the 1997 Land Cover Map of Connecticut (Prisloe and others, 2002). The data are derived from $30-\mathrm{m}$ pixel LandSat imagery (see following section). Land cover and land use in the watershed currently are dominated by deciduous and mixed deciduous and coniferous forest, with smaller areas of agriculture (primarily hay and corn), urban, and residential land use. Approximately 1.3 percent of the watershed is comprised of open-water surfaces, including lakes, small ponds, streams, and reservoirs.

\section{Water Use}

Water use in the watershed is primarily domestic, supplied from groundwater. The majority of withdrawals from private wells are for domestic water supply. Several public water supply systems are located in the watershed, all of which use groundwater as the source. Groundwater withdrawals for the watershed, on the basis of recent information from the suppliers, are compiled on table 1 . The three large public supply systems with documented pumping rates and diversions are Watertown Fire District, Heritage Village, and United Water. There are also nine smaller systems located within the watershed with substantial estimated withdrawals provided on table 1. Groundwater withdrawals from individual home wells are estimated to be $1.46 \mathrm{Mgal} / \mathrm{d}$ on the basis of an assumed water-use rate that is the same as that for customers of United Water (74 gal/d per person), and a population served by individual home wells of approximately 19,700 people. The United Water rate was used because this system supplies rural areas that are similar to areas with private wells. The population estimate is calculated as the difference between the total population in the watershed, estimated to be 34,000 people (Pomperaug River Watershed Coalition, 2001) and the population served by public systems shown on table 1 (not including the population served by the Watertown Fire District, because these people are located outside of the watershed). The total groundwater withdrawal from the watershed for the year 2001, assumed to be representative for this study, is therefore $3.76 \mathrm{Mgal} / \mathrm{d}$. Much of this water is returned to the watershed through septic systems and sewer outfalls.

Water diversions that are registered (in operation before 1983) or permitted with the Connecticut DEP for surfacewater and groundwater sources are listed on table 2. Some of the surface-water diversions listed on table 2 are not currently used but remain potentially active. Some of the diversions that are used, notably the Watertown Fire District wells and part of the pumpage from the Heritage Village water system, are diverted outside of the watershed, and therefore are entirely lost to the watershed. The out-of-watershed diversions are in effect consumptive uses of water. Additionally, surface-water diversions are used for irrigation in some areas; however, the magnitudes of these diversions are not reported and are considered to be sporadic compared to the more continuous groundwater withdrawals.

The Bronson-Lockwood Reservoir augments water supply to the Watertown Fire District well field. The amount of water released specifically for flow augmentation is not fully documented, and the accuracy of release quantity estimates is unknown. However, during periods of low flow, the reservoir releases are channeled into recharge ponds within the well field and are used to maintain low flows in the Nonnewaug River. A review of reservoir releases for the 6-month period from January 1, 2004, through July 11, 2004, indicates water is stored within the reservoir during periods of high flow and released during periods of low flow (Ernie Coppock, Watertown Fire District, written commun., 2004). Additionally, overflow from the Pomperaug River into a series of three ponds, formed in abandoned gravel pits adjacent to the river on the O\&G mining property, provides considerable storage of water during flood events that overtop the river banks and allows water to enter the pond system. This water is returned to the river through an outlet structure (weir).

\section{The Precipitation-Runoff Model}

The PRMS, developed by the USGS (Leavesley and others, 1996) simulates the hydrologic-system response to different land-use, water-use, and climatic conditions and will provide water-quantity information required for assessment of water allocation and instream flow. PRMS has been used to evaluate the effects of changes in land use and land cover on streamflow and hydrologic regimes in watersheds (Risley, 1994).

The PRMS modeling strategy developed for the Pomperaug River watershed is based on dividing the watershed into subunits within which a daily water balance is calculated from climatic input variables and hydrologic processes that can be characterized. The watershed subunits are called hydrologic response units (HRUs) and form the basic structure of the model. The modeling strategy included the following specific objectives:

- Develop a parameterization strategy that is objective and transferable to other watersheds in Connecticut.

- Distribute the HRUs to address management issues and hydrologic complexity in the watershed.

- Develop a method for determining effective impervious surface from LandSat-derived impervious surface data from Connecticut. 
Table 1. Groundwater-use data for the Pomperaug River watershed, Connecticut.

[Q, discharge; Mgal/d, million gallons per day; Stdev, standard deviation; gal/d, gallons per day; est., estimated; data from individual water companies]

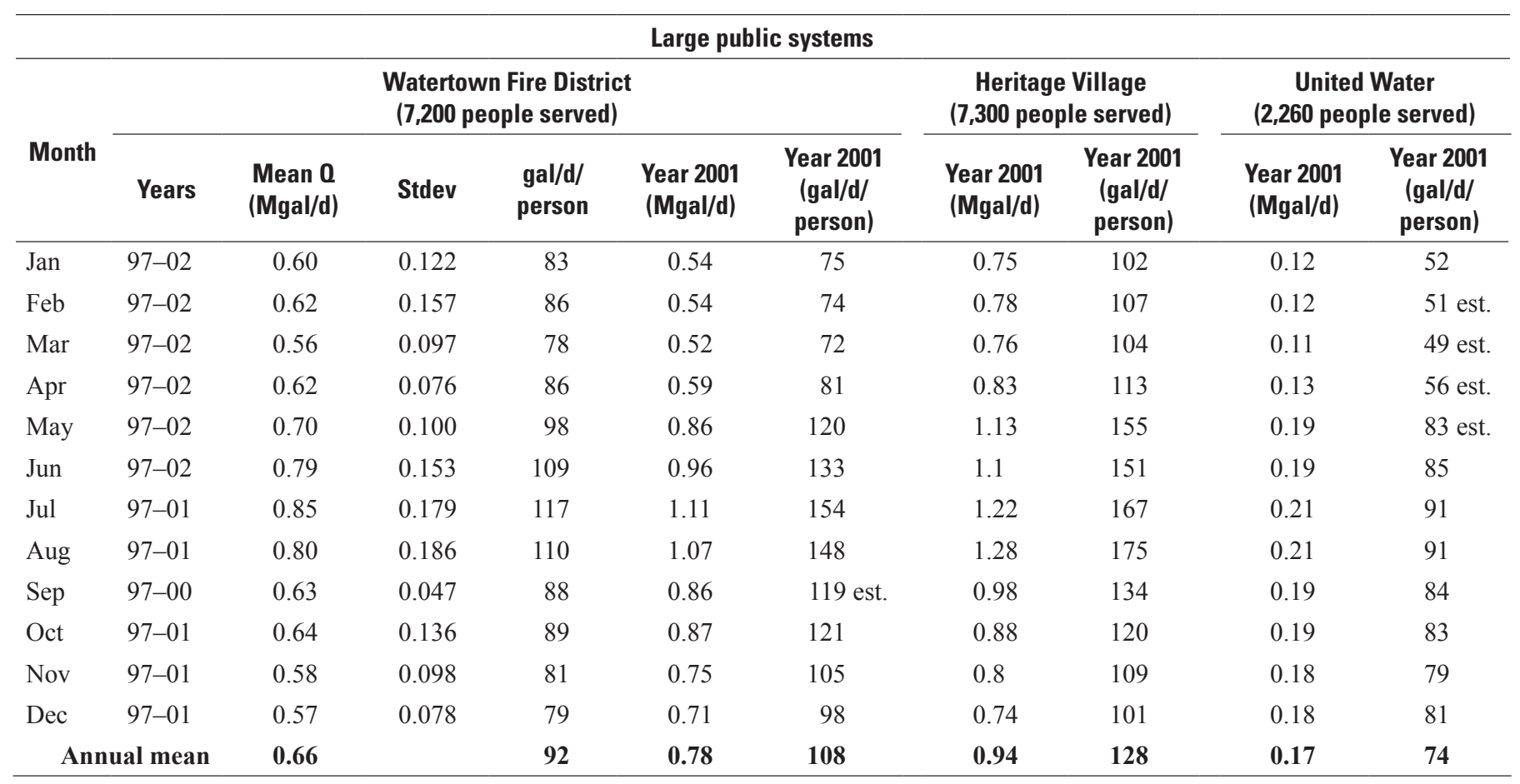

\begin{tabular}{lrc}
\hline \multicolumn{1}{c}{ Small public systems } \\
\hline Name & Population served & $\begin{array}{c}\text { Mgal/d' } \\
\text { est. }\end{array}$ \\
\hline Heritage Hill Condominiums & 120 & 0.01 \\
Romatic Manufacturing & 120 & 0.01 \\
Quassuk Heights Condominiums & 108 & 0.01 \\
Southbury Training School & 1,730 & 0.16 \\
Town in Country Condominiums & 240 & 0.02 \\
Woodbury Knolls Condominiums & 258 & 0.03 \\
Woodbury Place Condominiums & 72 & 0.01 \\
Nonnewaug High School & 850 & 0.09 \\
Woodlake Tax District & 1,200 & 0.07 \\
\multicolumn{1}{c}{ Total } & $\mathbf{4 , 6 9 8}$ & $\mathbf{0 . 4 1}$ \\
\hline
\end{tabular}

${ }^{1}$ Estimated annual use based on $92 \mathrm{gal} / \mathrm{d} /$ person (average Watertown Fire District use). 
Table 2. Registered and permitted water diversions in the Pomperaug River watershed, Connecticut.

[Mgal/d, million gallons per day; $\mathrm{ft}^{3} / \mathrm{s}$, cubic feet per second; DMR, Connecticut Department of Mental Retardation]

\begin{tabular}{|c|c|c|c|c|c|c|c|}
\hline \multirow{2}{*}{ Name } & \multirow{2}{*}{ Status } & \multicolumn{2}{|c|}{ Quantity } & \multirow{2}{*}{ Source } & \multirow{2}{*}{ Use } & \multirow{2}{*}{$\begin{array}{l}\text { Subwatershed } \\
\text { (see fig. 2) }\end{array}$} & \multirow{2}{*}{ Town } \\
\hline & & Mgal/d & $\mathrm{ft}^{3} / \mathrm{s}$ & & & & \\
\hline Heritage Inn \#1 & Permitted & 0.377 & 0.58 & Groundwater & Domestic & Pomperaug & Southbury \\
\hline O\&G Industries & Permitted & 0.65 & 1.01 & $\begin{array}{l}\text { Groundwater/ } \\
\text { surface water }\end{array}$ & Industrial & Pomperaug & Southbury \\
\hline DMR-Southbury Training School \#1 & Registered & 0.144 & 0.22 & Groundwater & Domestic & Pomperaug & Southbury \\
\hline DMR-Southbury Training School \#2 & Registered & 0.288 & 0.45 & Groundwater & Domestic & Pomperaug & Southbury \\
\hline DMR-Southbury Training School \#3 & Registered & 0.36 & 0.56 & Groundwater & Domestic & Pomperaug & Southbury \\
\hline Heritage Village Water Company \#4 & Registered & 0.504 & 0.78 & Groundwater & Domestic & Pomperaug & Southbury \\
\hline Heritage Village Water Company \#5 & Registered & 0.324 & 0.5 & Groundwater & Domestic & Pomperaug & Southbury \\
\hline Town of Southbury-Berry Farm & Registered & 2 & 3.09 & Pond/surface water & Irrigation & Pomperaug & Woodbury \\
\hline Town of Southbury-Berry Farm & Registered & 2 & 3.09 & River/surface water & Irrigation & Pomperaug & Woodbury \\
\hline Town of Southbury-Berry Farm & Registered & 2.3 & 3.56 & River/surface water & Irrigation & Pomperaug & Woodbury \\
\hline Town of Southbury-Berry Farm & Registered & 3.3 & 5.11 & Pond/surface water & Irrigation & Pomperaug & Woodbury \\
\hline United Water (Aquarion) \#1 & Registered & 0.144 & 0.22 & Groundwater & Domestic & Nonnewaug & Woodbury \\
\hline Watertown Fire District \#3 & Registered & 0.274 & 0.42 & Groundwater & Domestic & Nonnewaug & Woodbury \\
\hline Watertown Fire District \#4 & Registered & 0.31 & 0.48 & Groundwater & Domestic & Nonnewaug & Woodbury \\
\hline Watertown Fire District \#5 & Registered & 0.187 & 0.29 & Groundwater & Domestic & Nonnewaug & Woodbury \\
\hline Watertown Fire District \#6 & Registered & 0.396 & 0.61 & Groundwater & Domestic & Nonnewaug & Woodbury \\
\hline Watertown Fire District \#7 & Registered & 0.167 & 0.26 & Groundwater & Domestic & Nonnewaug & Woodbury \\
\hline Watertown Fire District \#8 & Registered & 0.176 & 0.27 & Groundwater & Domestic & Nonnewaug & Woodbury \\
\hline Watertown Fire District \#9 & Registered & 1.008 & 1.56 & Groundwater & Domestic & Nonnewaug & Woodbury \\
\hline Watertown Fire District & Registered & 0.4 & 0.62 & River/surface water & Domestic & Nonnewaug & Bethlehem \\
\hline Woodlake Tax District \#1 & Registered & 0.18 & 0.28 & Groundwater & Domestic & Pomperaug & Woodbury \\
\hline Woodlake Tax District \#3 & Registered & 0.104 & 0.16 & Groundwater & Domestic & Pomperaug & Woodbury \\
\hline Total & & 18.462 & 28.56 & & & & \\
\hline
\end{tabular}


- Develop surface-runoff, soil, subsurface-runoff, and groundwater-runoff parameters that are based on geology, land cover, and soil characteristics specific to each HRU.

- Evaluate model calibration by comparing the simulated streamflow and the observed streamflow using general objective functions including mean and standard deviation of streamflow, flow-duration curves, residual statistics, and flow relations among streamgages.

The primary objective of the watershed modeling study was to simulate streamflow response so that the statistical characteristics of the daily hydrograph are reproduced with sufficient accuracy to assess water availability, groundwater and surface-water interaction, instream-habitat conditions, and changes in streamflow and groundwater recharge resulting from changes in land use and water use. As such, accurately simulating the magnitude and timing of streamflow for a specific day is of secondary importance. For this reason, the primary calibration objective functions for the model are longer-term statistical measures of runoff, including flow-duration curves, the mean and standard deviation of component runoff volume, and general characteristics of the hydrograph shape, especially base-flow recessions and groundwater contribution to streamflow.

\section{General Description of the Precipitation Runoff Modeling System (PRMS)}

The PRMS model is comprised of three computational layers: the climate/soil interaction, which computes the surface-water balance, and two subsurface reservoirs, which route excess precipitation through shallow (subsurface) and deep (groundwater) reservoir layers. In this study, the subsurface runoff is conceptualized to be similar to interflow and consists of shallow and rapid groundwater flow, originating from ephemeral water tables perched above the deeper groundwater reservoir (aquifer), which may flow through the large secondary porosity in the subsurface just below the root zone. The climate/soil layer is where water input from precipitation, water loss from evapotranspiration, and direct surface runoff from impervious surfaces and variable-source contributing areas is generated. The variable-source contributing areas consist of soils adjacent to streams and wetlands that become saturated for short periods generating direct runoff by preventing infiltration. The model accounts for snow interception and estimates snow accumulation and snowmelt on the basis of temperature inputs, computed solar radiation, and various snowmelt process functions driven by elevation and other geographic factors. As such, the model parameterization process is described most easily from the standpoint of climate/soil-water balance and runoff functions.

PRMS computes the water balance and runoff from a series of independent HRUs defined for the watershed. Runoff from each HRU, in the daily time step, is simply the addition of the three runoff components (surface runoff, subsurface runoff, and groundwater runoff) computed for each HRU. The basic model processes and input data requirements needed for each HRU are summarized on table 3. The model has the option to account for the timing of runoff, including overland flow and channel routing, on less than daily time steps. This study employed the daily time step without routing on the basis of an analysis of the effects of routing on the downstream accumulation of discharge.

Table 3. Data and parameter requirements for the Precipitation Runoff Modeling System (PRMS) model.

[HRU, hydrologic response unit]

\begin{tabular}{|c|c|}
\hline \multicolumn{2}{|r|}{ Model input data } \\
\hline Type & Description \\
\hline Domain & $\begin{array}{l}\text { Discretized land areas of similar hydrologic } \\
\text { response, based on elevation, latitude, and } \\
\text { slope of each HRU, including vegetation } \\
\text { cover of each HRU. May or may not be based } \\
\text { on subwatershed delineation. }\end{array}$ \\
\hline Flow & $\begin{array}{l}\text { Discharge as a function of time step at outflow } \\
\text { (at Pomperaug River streamgage) }\end{array}$ \\
\hline \multirow[t]{6}{*}{$\begin{array}{l}\text { Climate/ } \\
\text { meteorology }\end{array}$} & Air temperature \\
\hline & Precipitation \\
\hline & Saturation vapor pressure \\
\hline & Solar radiation (calculated or input) \\
\hline & Cloud cover \\
\hline & Potential evapotranspiration (calculated or input) \\
\hline \multicolumn{2}{|r|}{ Modeled physical processes } \\
\hline Type & Description \\
\hline \multirow[t]{7}{*}{ Hydrology } & Interception capacity of vegetation (pervious) \\
\hline & Retention storage (impervious) \\
\hline & Overland flow routing parameters \\
\hline & $\begin{array}{l}\text { Groundwater and subsurface recession } \\
\text { parameters }\end{array}$ \\
\hline & Nominal storage in soil zone \\
\hline & $\begin{array}{l}\text { Parameters regulating evapotranspiration } \\
\text { potential of soil and groundwater zones }\end{array}$ \\
\hline & Parameters regulating infiltration \\
\hline \multirow[t]{4}{*}{ Snowpack } & $\begin{array}{l}\text { Lapse rate correcting air temperature at gages to } \\
\text { elevation of HRU }\end{array}$ \\
\hline & Threshold temperature for precipitation as snow \\
\hline & Density of new snow \\
\hline & Water-holding capacity of snowpack \\
\hline
\end{tabular}




\section{Model Sensitivity and Uncertainty}

The estimated streamflow volume simulated by the model is sensitive to key parameters and physical characteristics of each HRU that control the climatic water balance, including the method for distributing station-based precipitation and temperature input data to each HRU (the xyz module of latitude, longitude, and elevation), the method for estimating PET (Jensen-Haise module), the soil water capacity and rooting depth, direct soil recharge to the groundwater reservoir, vegetation type and ground cover (including percent impervious surface), and the snow accumulation and melt parameters. The PET and snow parameters are determined primarily by general climatic characteristics of the region and are estimated from general functions that are not typically changed. Exceptions to this are temperature thresholds set for snow accumulation and melt. Land-cover characteristics and soil properties are determined directly from GIS information. The xyz distribution module uses a 3-dimensional distribution function estimated from the station data to assign temperature and precipitation on the basis of its xyz coordinates. The method preserves the mean values of the input precipitation and temperature records derived from the station data.

The timing of streamflow, the shape of the hydrograph, and the amount of water assigned to the surface, subsurface, and groundwater reservoirs are controlled by those parameters that control water storage and routing through the watershed. These include surface storage parameters (surface runoff is not routed, instead it is all assumed to enter the stream within the 1-day time step), subsurface storage parameters and routing coefficients, and groundwater storage parameters and routing coefficients. All these parameters are subject to calibration and alter the rate at which excess precipitation enters the stream and the source of streamflow. In this study, these parameters were derived from physical data to the extent possible and as such were not calibrated. The methods used to determine these values are described in later sections of the report.

Sources of model uncertainty include (1) those associated with the input data such as nonrepresentative station data and errors in the data itself, (2) those associated with incomplete model representation of watershed processes, (3) those associated with unknown factors not accounted for in the model including changes in land use and water use during the simulation period, unknown water diversions, and changes in off-channel flood-plain storage during the simulation period, (4) those associated with differences in scale of the subbasins that comprise the HRUs, and (5) those associated with misclassification of land-cover data. Generally, systematic errors are indicative of an incomplete model, missing data or unknown factors, or a consistent bias in input data, and random errors are associated with random error in the input data.

In some cases, particularly with regard to extreme input events, a single large input error can cause large errors in mean statistics, especially considering the effect of persistence in the error resulting from storage effects. For example, during a month with a mean streamflow of $120 \mathrm{ft}^{3} / \mathrm{s}$, if one event during that month was simulated to be $2,000 \mathrm{ft}^{3} / \mathrm{s}$ rather than $200 \mathrm{ft}^{3} / \mathrm{s}$, the monthly mean would be increased by 50 percent. A flow rate of $2,000 \mathrm{ft}^{3} / \mathrm{s}$ could be generated by an excess rainfall of 2 in. over the watershed, indicating that a 2 -in. error in a daily precipitation record would readily result in large errors in the monthly mean. Additionally, a large precipitation event can also cause a high-flow memory for several days or weeks after the event such that one erroneously large precipitation event can lead to several days or weeks of simulated streamflow that are too high.

\section{Representation of the Watershed-Hydrologic Response Units (HRUs)}

PRMS computes the water balance for each HRU in the model. The HRU can be a small watershed or any delineated area that represents a region from which the desired hydrologic abstraction (variable) is estimated. For this study, the variable of interest is runoff, including surface runoff, subsurface runoff, and groundwater runoff. As such, the HRUs are delineated for all areas where an estimate of runoff is desired or needed. The hydrologic homogeneity of an HRU is also an important consideration in order to reduce variability within the HRU and thus facilitate more accurate water-balance computations. However, because the scale and extent defining hydrologic homogeneity varies depending on the process considered, too many HRUs can introduce unnecessary and extraneous complexity into the model. Therefore, the HRU delineation balances the need for homogeneity across all processes and scales with the spatial complexity needed for the desired data output and management application.

The HRU delineation, therefore, is based on the need to be able to model streamflows and watershed processes at locations where specific management questions will be addressed, including those associated with groundwater recharge, surfacewater management, land-use and land-cover change (such as urban development), and instream-flow requirements for the Pomperaug River and its tributaries. An inherent assumption in the HRU boundaries is that they follow a flow boundary represented by a watershed (or subwatershed) divide and (or) a river or stream (flow line) and that the groundwater flow boundary coincides with the surface-water flow boundary.

The HRU delineation is designed to sufficiently represent the diversity and complexity of geologic, water-use, and land-use environments in the watershed so that these can be explicitly evaluated. This allows for an assessment of watershed response within the different HRU environments defined in the model. Additionally, model output must be suitable to provide a distributed streamflow network within the watershed with enough detail so that water-management and habitat questions that relate to the quantity, location, and timing of daily streamflows can be addressed. The HRU boundaries are provided on figure 3 . 


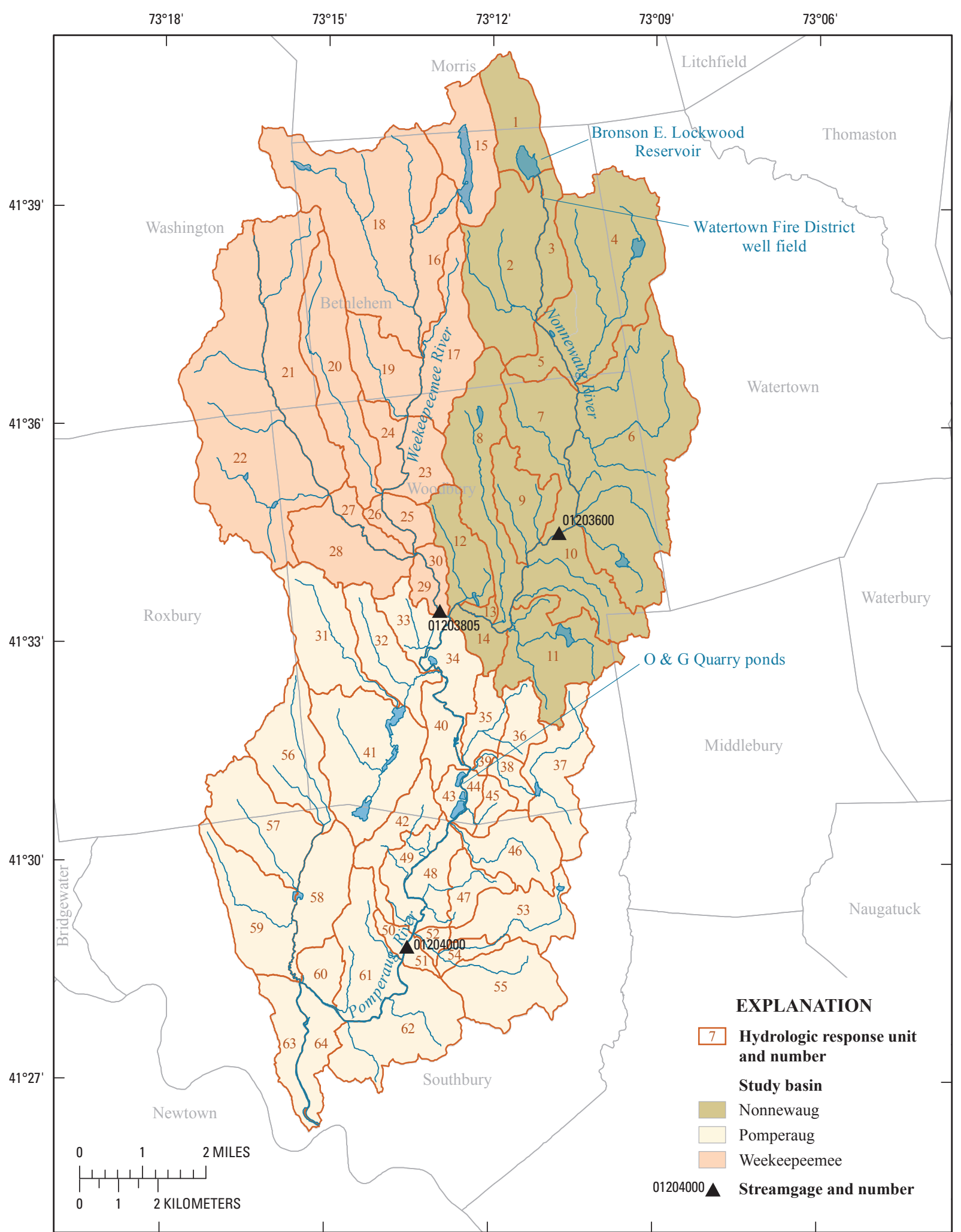

Base from U.S. Geological Survey, 1:24,000, 1969 to 1984

Connecticut State Plane projection

Figure 3. Pomperaug River watershed, Connecticut, showing hydrographic features and hydrologic response unit boundaries. 
The following specific criteria were used for HRU selection and delineation:

- Retain general subwatershed basis for delineation so that model output can be directly translated to a streamflow at desired locations.

- Provide streamflow for specific habitat reaches (for use in a separate study by Parasiewicz and others, 2007).

- Provide a diversity of HRUs dominated by developed and undeveloped areas (for both the existing and future conditions).

- Provide a diversity of HRUs primarily underlain by coarse glacial stratified deposits and relatively shallow slopes and underlain by till and bedrock with steeper slopes.

- Explicitly delineate HRUs to the outlet of those reservoirs where specific management questions will be asked and evaluated.

\section{Precipitation, Temperature, and Geographic Input Data}

In order to use a daily time step, PRMS requires daily precipitation and daily maximum and minimum air temperature as input variables. For this study, two data sets were compiled from weather stations in the vicinity of the Pomperaug River watershed. The first data set consisted of daily precipitation and daily maximum and minimum air temperatures from 12 National Climatic Data Center, National Weather Service (2002) coop stations including the Woodbury station, which is the only weather station in the watershed (fig. 1). The period of record for this data set begins October 10,1975, and ends September 30, 1999. Unfortunately, a number of these stations were discontinued on or before September 30, 1999. Because of this, and to provide the potential for hourly simulations in future studies, a recent data set consisting of daily precipitation and daily maximum and minimum air temperature was compiled for the period January 1, 1998, to September 30, 2005, from the Woodbury station and three additional stations with hourly recording maintained by NOAA and distributed by the Northeast Regional Climate Center (NRCC) (Keith Eggleston, Northeast Regional Climate Center, written commun., 2006).The four weather stations are Hartford, Danbury, Meriden, and Woodbury (fig. 1). The annual precipitation totals (by water year, October 1 to September 30) derived from the model input data for 1976 to 2005 are shown on figure 4 .

The comparability of the two weather data sets was evaluated on the basis of a statistical comparison of the 457 days of overlapping information (July 1, 1998, to September 30, 1999). The total precipitation from the two data sets for the period of comparison was nearly equal (within 1 percent of each other); however, the AET simulated from the model was higher using the input data of the four stations. The higher AET is probably because of somewhat higher minimum temperatures. The PRMS model simulations using the two input data sets showed differences in mean simulated streamflows of 3 percent and simulated recharge less than 7 percent. The mean simulated streamflow from the input data of the 4 stations was closer to the observed mean than the simulation from the data set of the 12 stations. This comparison indicates that the two input data sets do not affect the resulting simulated runoff to a large degree, and it is assumed that they are compatible for application in longterm simulations. However, for comparative and calibration purposes, the two data sets are treated separately throughout this report, except where a long-term record is desired.

In addition to the required weather input data, observed streamflow for the Pomperaug River at Southbury (USGS station 01204000) was input to the model. These data were used for model optimization and provide the comparative data necessary to evaluate the accuracy of the model-simulated streamflow. In addition to the Pomperaug River streamflow data, data for the two primary tributaries to the Pomperaug, the Weekeepeemee River (USGS station 01203805) and Nonnewaug River (USGS station 01203600), also were compared. The observed Pomperaug River streamflow data were available for the entire period of the simulation (19752005), whereas the Weekeepeemee and the Nonnewaug data were available from October 1, 2000, through June 30, 2005.

One of the key objectives of this study was to use available GIS data (Viger and others, 1998) as the basis for developing the spatial distribution patterns of the input data and process-function parameters. The GIS data used in the parameterization process included the following physical information obtained from statewide digital coverages and tabulated for each HRU:

- Percent coarse glacial stratified deposits and till and bedrock, and aquifer properties.

- Land-cover characteristics.

- Percent impervious surface.

- Soil information and percent class D soils (hydrologic soil class D-low permeability clay and silt dominated soils).

- Topography and slope.

- Drainage density.

The latitude and longitude (and albers coordinates), elevation, and aspect of each HRU were used to distribute the air temperature and precipitation data from the weather-station network to each HRU in the watershed. Elevation and aspect of each HRU also were used to determine snowmelt characteristics. The soil and ground-cover type were used to determine the interception and storage characteristics of the soil and vegetative cover, and the evapotranspiration capacity.

The pertinent GIS data for the watershed and its translation to each HRU are shown on figures 5 through 10. 
The methods for translating the GIS information into the model parameters is summarized for selected parameters in the following sections.

\section{Parameterization and Calibration of the Model}

The initial model parameters were determined on the basis of techniques developed by Viger and others (1998) and climate-data distribution techniques developed by Hay and others (2000) and Hay and McCabe (2002). This section describes the parameters and parameter-estimation methods developed specifically for this study. This section also describes the model calibration and calibration results.

Two fundamental model parameterization and calibration targets are: (1) The long-term water balance and streamflow (mean total runoff), which includes the climate and soil water balance; and (2) the magnitude of the flux of the three runoff components and the hydrograph shape (variability of runoff), which includes the surface, subsurface, and groundwater-runoff components. The annual water balance is calibrated first in order to achieve the proper balance of climatic variables and thus the proper runoff magnitude. Given an acceptable long-term seasonal water balance, the mean surface fluxes are assumed to be sufficiently modeled. The runoff partitioning (routing) parameters are calibrated after the mean water balance. These parameters include those associated with surface-runoff, storage, and infiltration processes; subsurface-runoff, storage, and infiltration processes; and groundwater-runoff and storage processes.

The following describes the approach to calibration of the model parameters in order of priority. Geomorphic, land-use, land-cover, and soil-type parameters for each HRU are considered fixed and not subject to calibration. The parameterization proceeds from those elements of the water balance for which the greatest knowledge is available.

The sensitivity of the model results to various input parameters that control the apportionment of streamflow was assessed during the model calibration. The model response to precipitation inputs and simulated spatial distribution of these

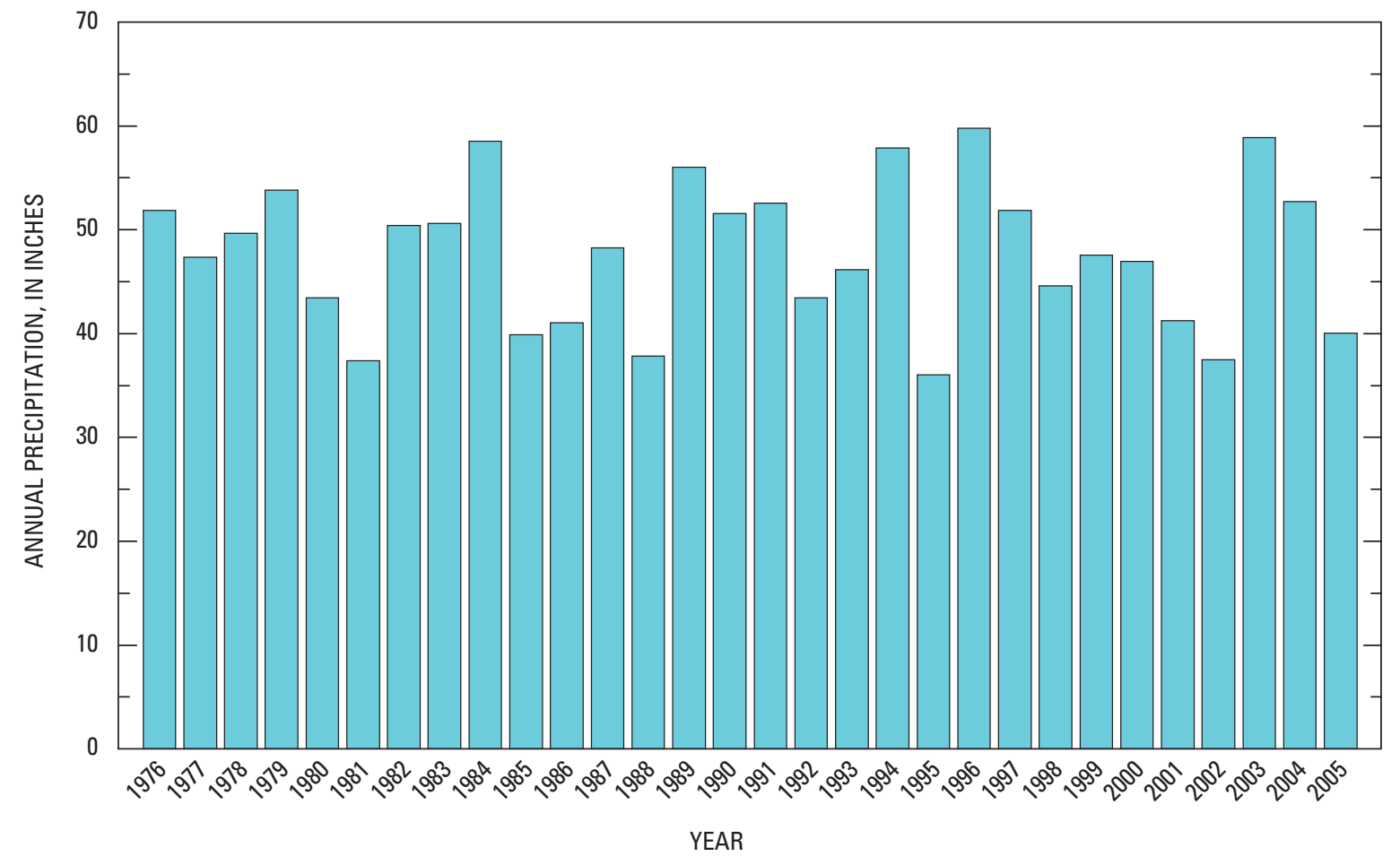

Figure 4. Annual precipitation totals for water years 1976 to 2005 spatially averaged from 12 surrounding National Weather Service coop stations. 

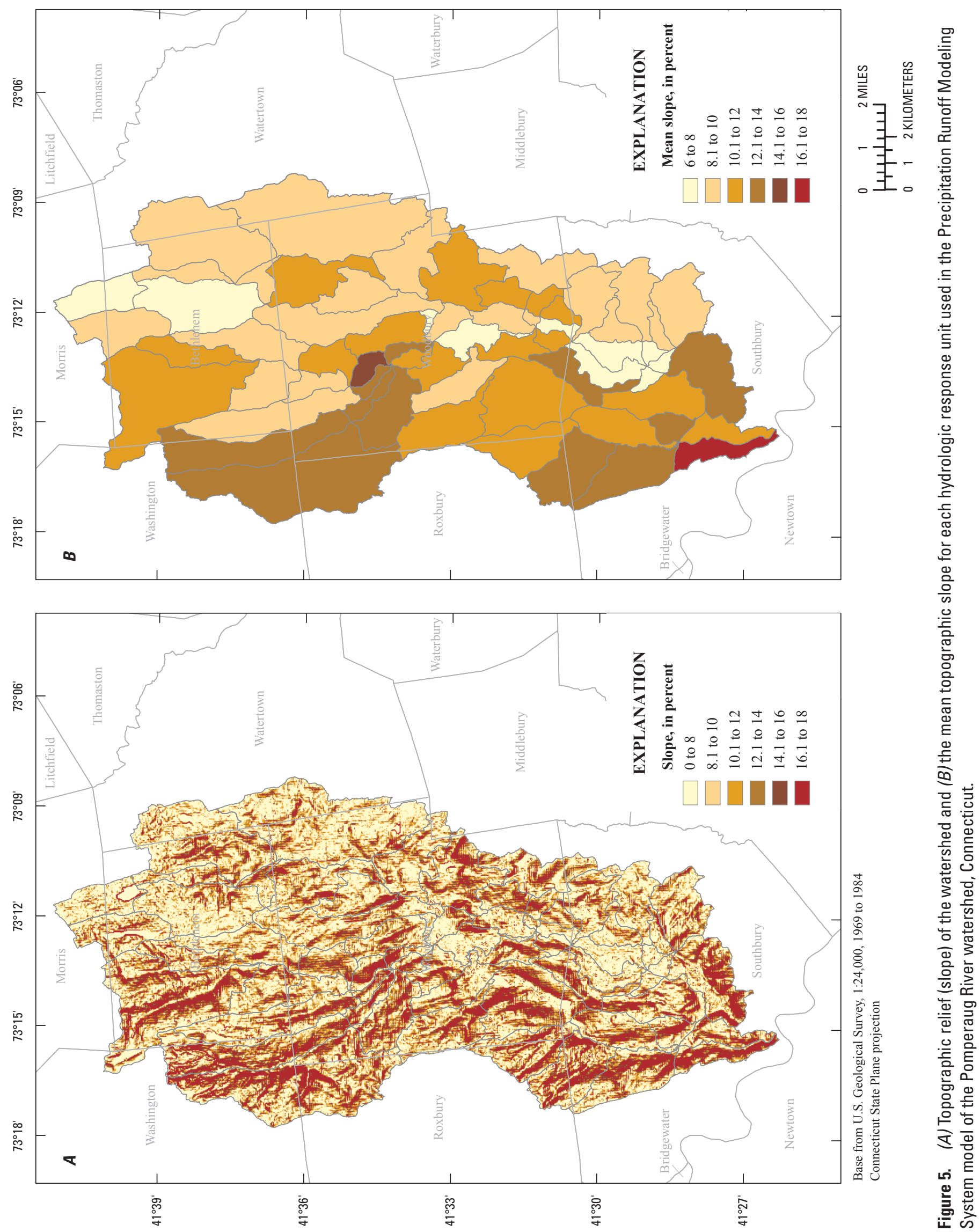

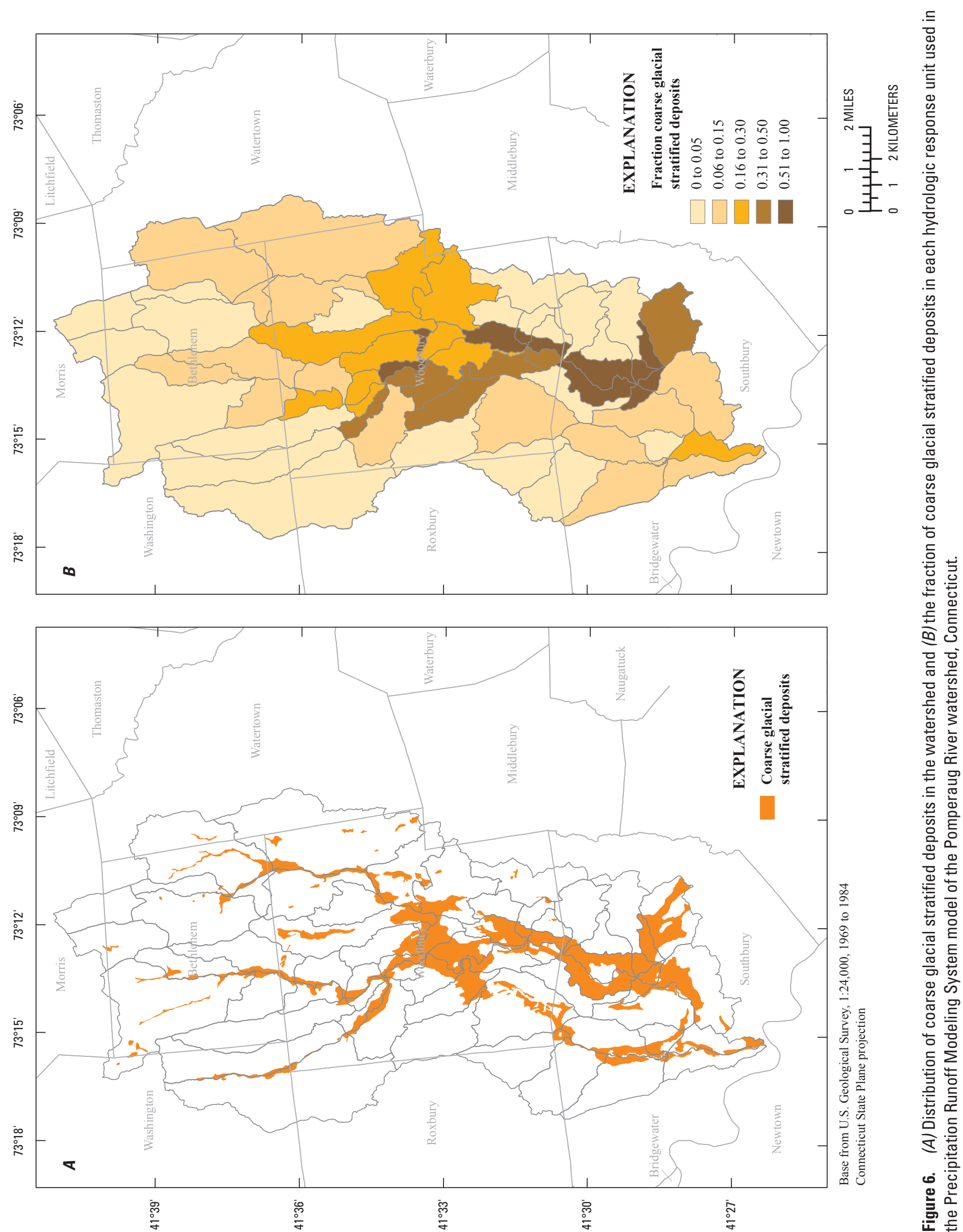

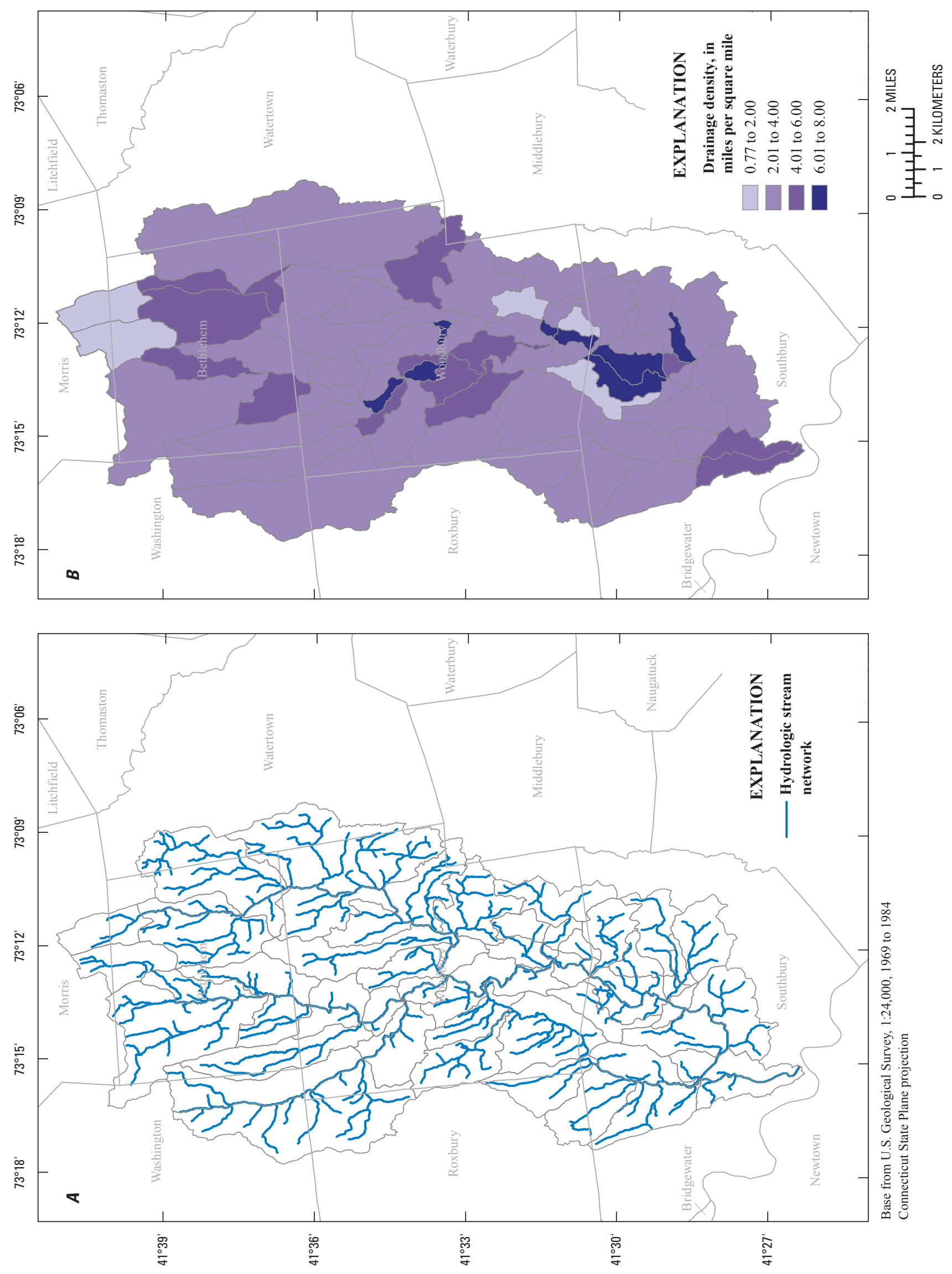

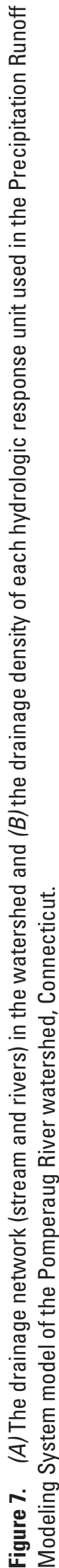



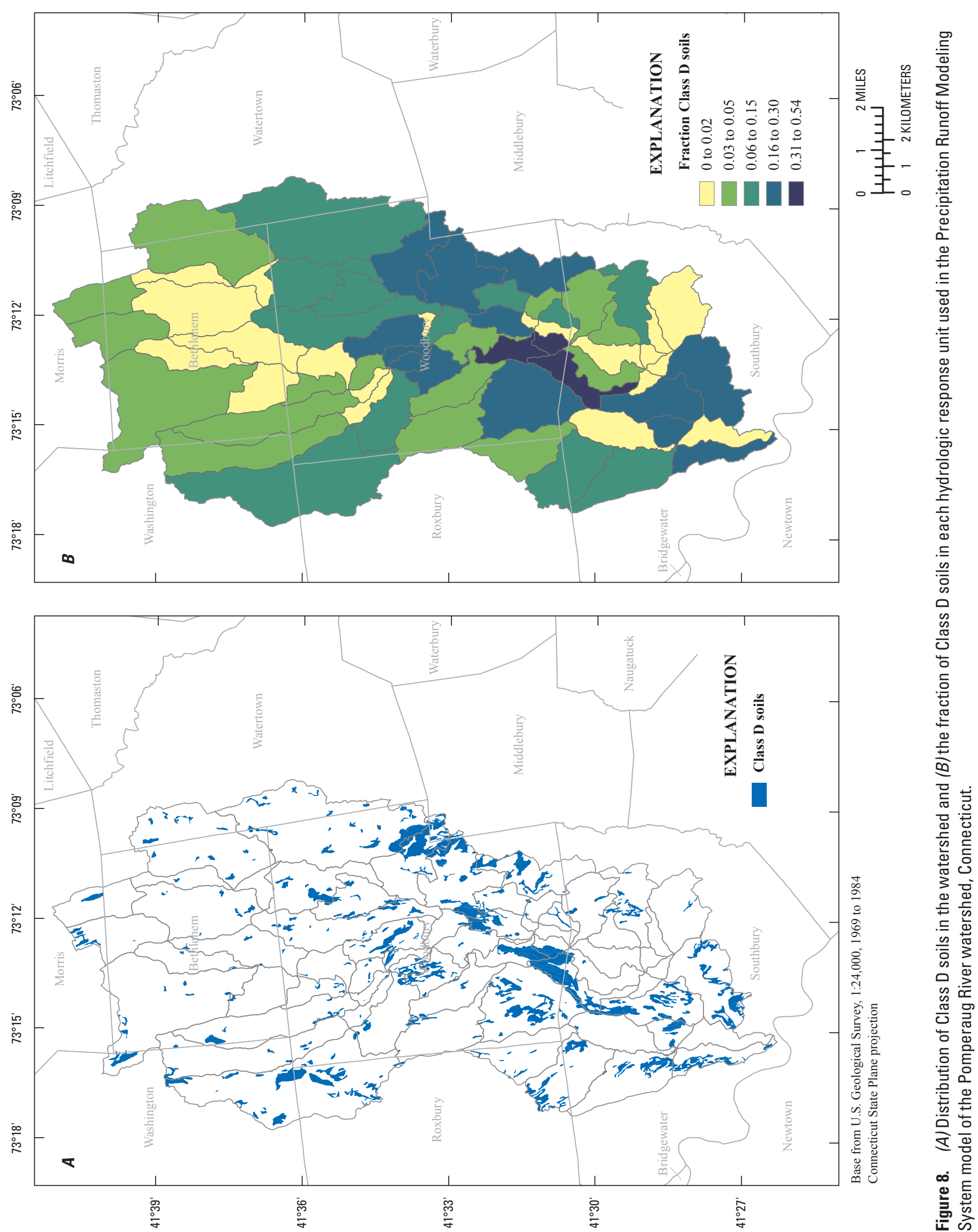

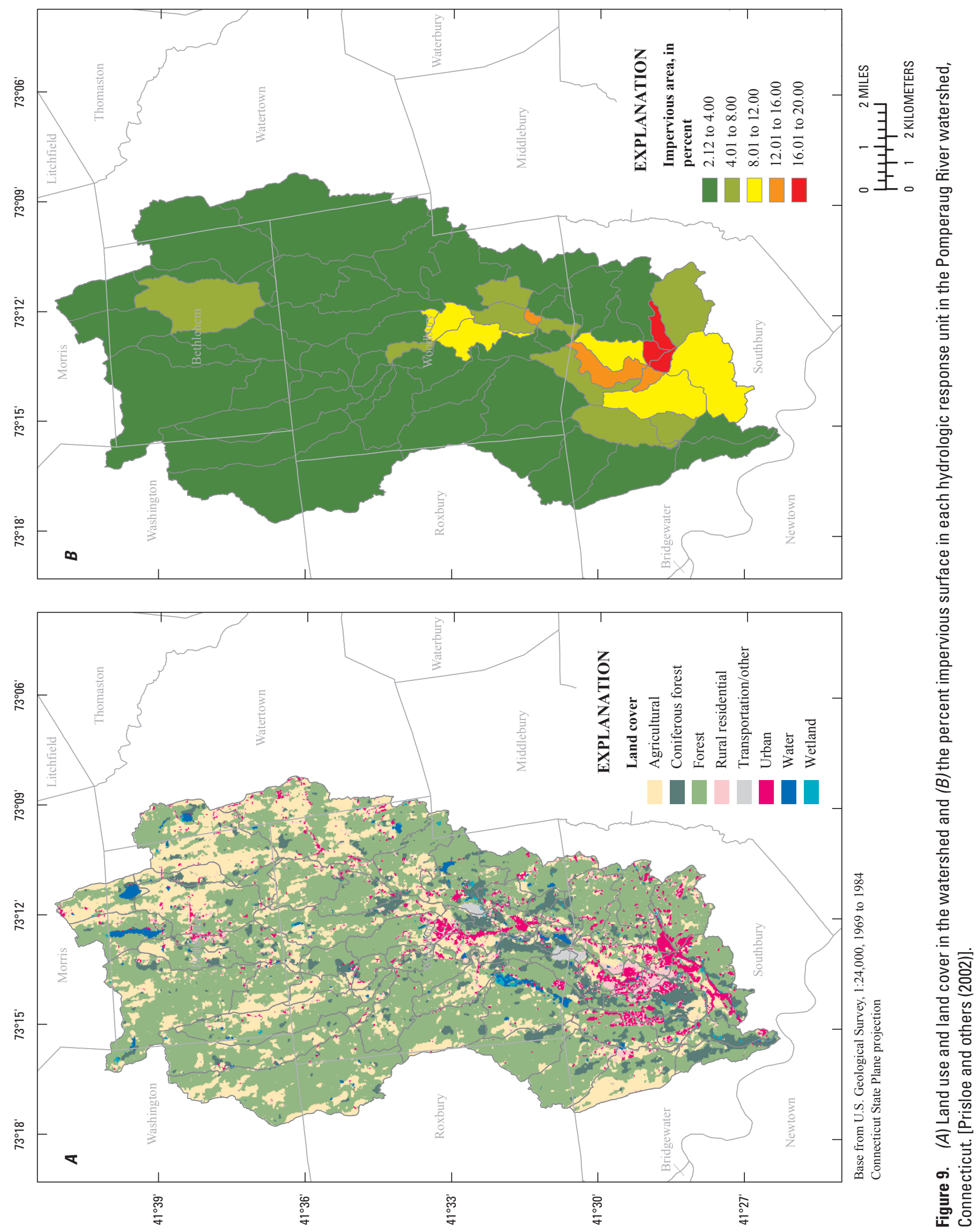

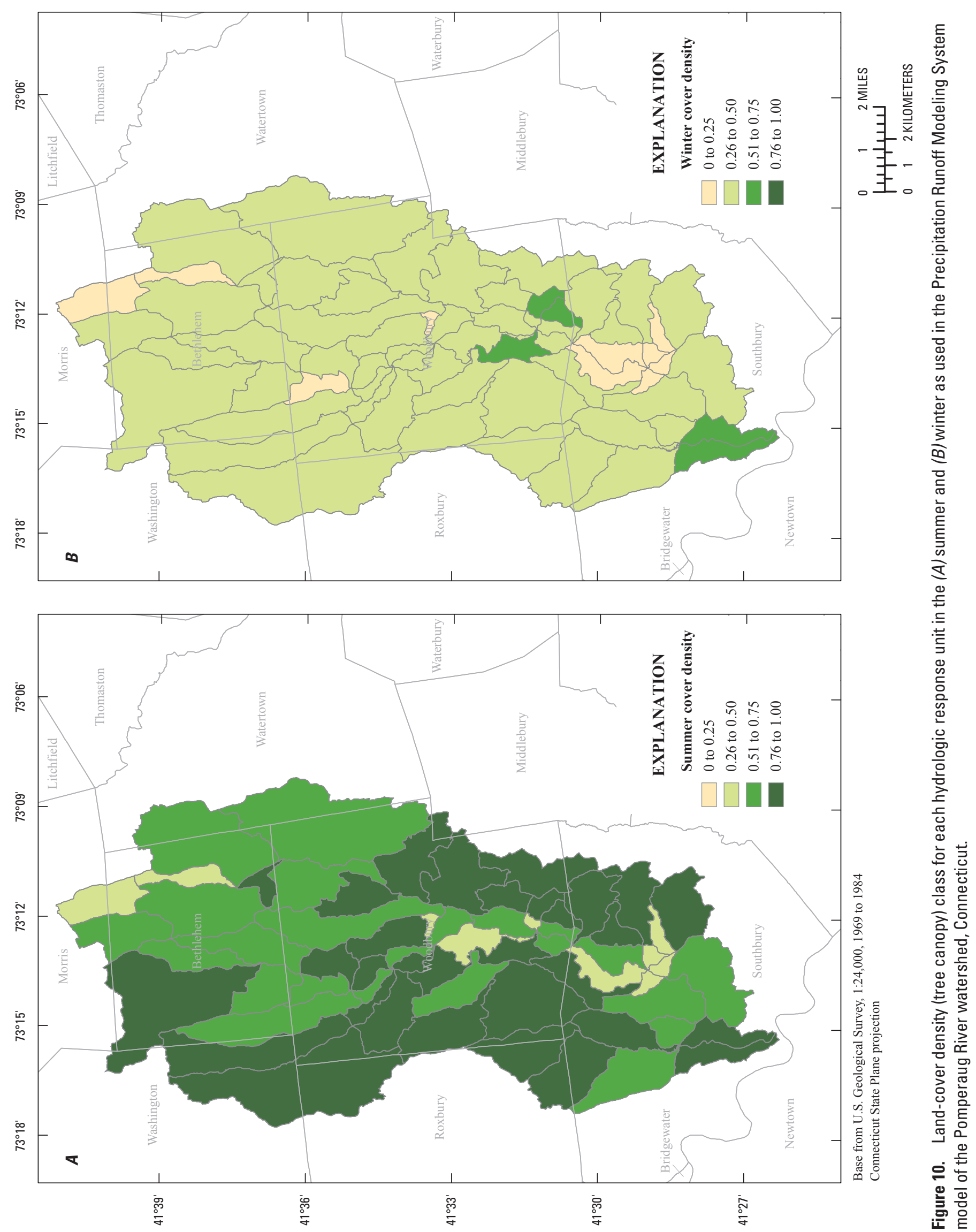
inputs was not specifically assessed and was considered to be independent of calibration. These inputs and the associated distribution were assumed to be fixed and as such serve as a limitation to the model. The parameters tested included the groundwater-runoff coefficient, the subsurface-runoff coefficients (horizontal and vertical), and the soil storage coefficients. On the basis of the analysis, the groundwater coefficient and the subsurface coefficients were important in controlling the shape of the hydrograph recession, and the soil storage and subsurface-runoff coefficients were important in controlling the amount of groundwater recharge. An optimization method was employed to determine reasonable values for the watershed mean groundwater-runoff coefficient and the subsurface-runoff coefficients, and physically based methods were used to assign unique values for these parameters to each HRU.

A method was derived to assign a value to the groundwater coefficient on the basis of the general knowledge of the hydrogeology of the watershed. The two subsurface routing parameters that were optimized were isolated and calibrated. Even though the general value of the parameters was not determined directly from physical characteristics of the watershed, the parameter values were distributed and assigned to each HRU on the basis of the physical characteristics of each HRU. The soil storage values were based on a conceptual model of soil depth and type.

\section{Water-Balance Considerations}

The general water-balance equation describing the streamflow hydrograph is as written:

$$
\mathrm{Qt}=\mathrm{P}-\mathrm{AET}-\mathrm{Ql}-\delta \mathrm{S},
$$

where

Qt is the streamflow for the river reach of
interest;
P is the precipitation falling on the watershed
upstream of the reach of interest;
AET is the actual evapotranspiration loss from
the watershed upstream of the reach of
interest;
Q1 is flow loss caused by diversions or sinks
upstream of the reach of interest; and
$\delta \mathrm{S} \quad \begin{aligned} & \text { is the change in water stored within the } \\ & \text { watershed upstream of the point of interest. }\end{aligned}$

The flow source components of Qt (surface runoff, subsurface runoff, and groundwater runoff) are simulated by PRMS, and thus the total streamflow is defined as:

$$
\mathrm{Qt}=\mathrm{Qsr}+\mathrm{Qss}+\mathrm{Qgw},
$$

where

Qsr is the surface-runoff component,
Qss
is the subsurface-runoff component, and
Qgw
is the groundwater-runoff component.

The components of the change in storage $(\delta \mathrm{S})$ are simulated by PRMS and are defined as:

$$
\delta \mathrm{S}=\delta \mathrm{Ssr}+\delta \mathrm{Sss}+\delta \mathrm{Ssoil}+\delta \mathrm{SSgw}
$$

where

$\delta \mathrm{Ssr} \quad$ is the change in surface-runoff storage,

$\delta$ Sss is the change in subsurface-runoff storage,

$\delta$ Ssoil is the change in soil water storage, and

$\delta \mathrm{Sgw}$ is the change in groundwater-runoff storage.

Assuming that $\delta \mathrm{Ssr}$ and $\mathrm{Q} 1$ are negligible, equation (1) can be written to define any one of the three runoff components, for example:

$$
\mathrm{Qss}=\mathrm{P}-\mathrm{AET}-(\delta \mathrm{Sss}+\delta \mathrm{Ssoil}+\delta \mathrm{Sgw})-(\mathrm{Qsr}+\mathrm{Qgw}) .
$$

Over a long enough period of time there is no change in storage $(\delta S=0)$, the simulated water balance should agree closely with the values reported earlier, with the ratio $\mathrm{Qt} / \mathrm{P}$ averaging 48 to 49 percent.

Qsr is determined by the model as a function of the impervious area assigned for each HRU and the contributingarea function. In this report, the effective impervious area was determined from the stream response during short-duration summer rainfall events and a priori assumptions regarding the contributing-area function (srunoff_smidx.f). If Qsr and Qgw can be defined, and the total runoff is known, the value for Qss can be calculated. Thus, defining the expected values for Qsr and Qgw provides the critical objective functions for the hydrograph component separation. Over a sufficient length of time, it can be assumed that $\delta \mathrm{S}=0$. Thus, given an expected value for Qgw and reliable estimates of the effective impervious area and contributing-area function, Qt at each observation point in the watershed can serve as the model objective function for the watershed. Expressing all terms in inches, for a sufficient length of time, $\delta$ t, equation 4 becomes:

$$
\mathrm{Qss} / \delta \mathrm{t}=\mathrm{P} / \delta \mathrm{t}-\mathrm{ET} / \delta \mathrm{t}-\mathrm{Qsr} / \delta \mathrm{t}-\mathrm{Qgw} / \delta \mathrm{t}
$$

Thus, the overall objective function for the water balance and hydrograph components is a function of the $\delta t$ and the water balance is thus evaluated for monthly and yearly values of $\delta$.

Over the long term, the groundwater component of the streamflow hydrograph can be assumed equal to the total groundwater recharge within a defined watershed. In the Pomperaug River watershed, the boundaries of the groundwater watershed are essentially equivalent to the watershed boundaries (Meinzer and Stearns, 1929), thus the long-term contribution of groundwater to streamflow in the Pomperaug River can be considered equal to the long-term recharge to the groundwater aquifers in the watershed. The definition of 
long-term from the standpoint of groundwater flow in the watershed is assumed to be on the order of several years and would depend on the specific history of recharge and discharge in response to annual weather patterns. In any case, annual changes in groundwater storage are likely to be much less than the total groundwater discharge over a typical period of 1 to 3 years. Meinzer and Stearns (1929) estimated that changes in groundwater storage over a 3-year period (1913-1916) were less than 7 percent of the total groundwater discharge.

A major consideration in assigning the groundwater component and evaluating groundwater recharge is defining what is meant by groundwater. For example, Meinzer and Stearns (1929) assumed that groundwater includes any precipitation that infiltrates the soil and reaches a zone of saturation, and that this water flows laterally downgradient towards streams and other discharge points within the geologic formation where it is subject to evapotranspiration.

From the PRMS modeling standpoint, however, two groundwater reservoirs - the subsurface and the groundwater reservoirs - are used to account for the movement of water that infiltrates past the root zone. Because they are below the root zone, neither of these reservoirs is subject to evapotranspiration. The distinction between the two runoff components is based on the characteristics of transport, which in turn are a function of the shallow surficial geologic materials and the interaction with surface waters. Shallow subsurface runoff is rapid groundwater runoff often occurring where shallow perched groundwater zones exist, where there is substantial bank storage, and where there is substantial secondary porosity in the shallow subsurface. Thus, the subsurface reservoir would be expected to occur in shallow till and weathered bedrock zones overlying till/bedrock aquifers.

Lateral flow out of the subsurface reservoir is generally more rapid than groundwater runoff but much slower than surface runoff; thus, the base flow can be considered derived from groundwater and some portion of the subsurface runoff that is sustained over longer timeframes than surface runoff. On the basis of Meinzer and Stearns (1929), Mazzaferro (1986b), and the automated base-flow separation methods (Rutledge, 1998), the component of total streamflow delivered by the groundwater reservoir on an annual basis would be expected to be in the range of 45 to 70 percent.

The automated base-flow separation methods provided estimates of groundwater runoff ranging from 60 to 70 percent. Considering the definition of groundwater runoff applied to the model assumptions, which assumes that rapid subsurface runoff is not groundwater runoff, it is anticipated that the simulated groundwater-runoff component would be less than the maximum value of 70 percent and more in the range of 60 percent, which is also closer to the base-flow separation estimates developed by Meinzer and Stearns (1929) and Mazzaferro (1986b) using manual methods.

\section{Climatic Variables-Precipitation, Temperature, and Evapotranspiration}

Six PRMS modules control the climatic inputs and outputs in the long-term water balance. These modules include the magnitude and distribution of precipitation and temperature (xyz module), magnitude and distribution of snowmelt (snow module), magnitude and distribution of evapotranspiration (potet module), magnitude of solar radiation (solrad module), distribution of solar radiation (soltab module), and the interception and evaporation of precipitation from vegetative surfaces (intcp module). All of these modules use basic assumptions regarding the relation between latitude, longitude, and elevation to define lapse rates and spatial patterns of temperature, precipitation, and solar radiation.

The values for the various parameters associated with the xyz, snowmelt, evapotranspiration, and solar-radiation modules are determined from the input climate data and GIS information for the watershed and are generally not subject to calibration and optimization. The methods and procedures for determining their values are discussed by Hay and others (2000) and Hay and McCabe (2002). Initial modeling indicated the climate parameterization provided good overall water-balance results. Precipitation, as snow or rain, temperature thresholds have been defined specifically for the Pomperaug River watershed and are assumed to be consistent for Connecticut as a whole.

The accuracy and appropriateness of the climate parameterization are based on comparison of the two fundamental climatic driving variables, the amount of precipitation and the potential evapotranspiration. The distributed average annual watershed-wide precipitation, calculated from the 12 stations in the vicinity of the study, was 48 in. for the period 1976-1999 and 46 in. for the period 1998-2005. These values are similar to the estimate of $47 \mathrm{in}$. made by Wilson and others (1974) for the watershed as whole. These data indicate the precipitation input and simulated distribution of precipitation in the watershed is appropriate. The PRMS model distributes the observed precipitation from the input station records to each HRU on the basis of the spatial and vertical relative position of the HRU. This distribution is done by first establishing a weighting function that is based on the spatial coordinates and elevations of the input station records. PRMS preserves the weighted precipitation time-series statistics from the input record. In this study, it is assumed that the input weather data are not subject to modification and are taken at face value after an initial level of quality control to remove erroneous data. In some cases, precipitation amounts and temperatures appear to be out of range relative to adjacent stations and knowledge of the observed response. For example, if the weather record for a station reports $10 \mathrm{in}$. of rainfall and surrounding stations report no rain or minor rain and there is no attendant observed change in the streamflow, then the 10-in. rainfall is considered a reporting error in the data. This level of quality control was 
done for obvious errors. For cases where a potential reporting error was not obvious, the data were left in the record.

The PRMS model simulates the PET from the input temperature data and computed incoming global solar radiation for the latitude and longitude of each HRU using the Jensen-Haise method (Leavesley and others, 1996). For 1999-2003, for which independently estimated PET data are available from the Hartford, Danbury, Meriden, and Oxford ${ }^{1}$ weather stations (Northeast Regional Climate Center, 2006), the estimated PET is $29 \mathrm{in}$. annually, which is comparable to the PRMS-simulated PET averaged for the watershed of 30 in. annually. The mean monthly error between the simulated and NRCC-estimated PET is 4 percent, and the Nash-Sutcliffe goodness-of-fit coefficient (Nash and Sutcliffe, 1970) for the daily record is 0.75 and for the

${ }^{1}$ Precipitation data from the Oxford station were not used in PRMS model because they contained numerous errors. monthly record is 0.88 , both indicating relatively good timeseries simulations fit. The simulated PET is higher during the summer months than the estimates made by the NRCC

(fig. 11). This discrepancy is likely because of a combination of the differences in the method of estimation and the fact that the PRMS distribution of PET is averaged over the entire watershed, whereas the NRCC estimate is not distributed.

\section{Interception}

The amount of precipitation intercepted is a function of the ground-cover characteristics (vegetative cover) for summer and winter conditions and the PET. Interception of precipitation is simulated by assuming a specific maximum quantity of precipitation is stored on vegetative surfaces during the summer (leaf on) and winter (leaf off) months. The assumed quantity is a function of the cover type and cover density, both

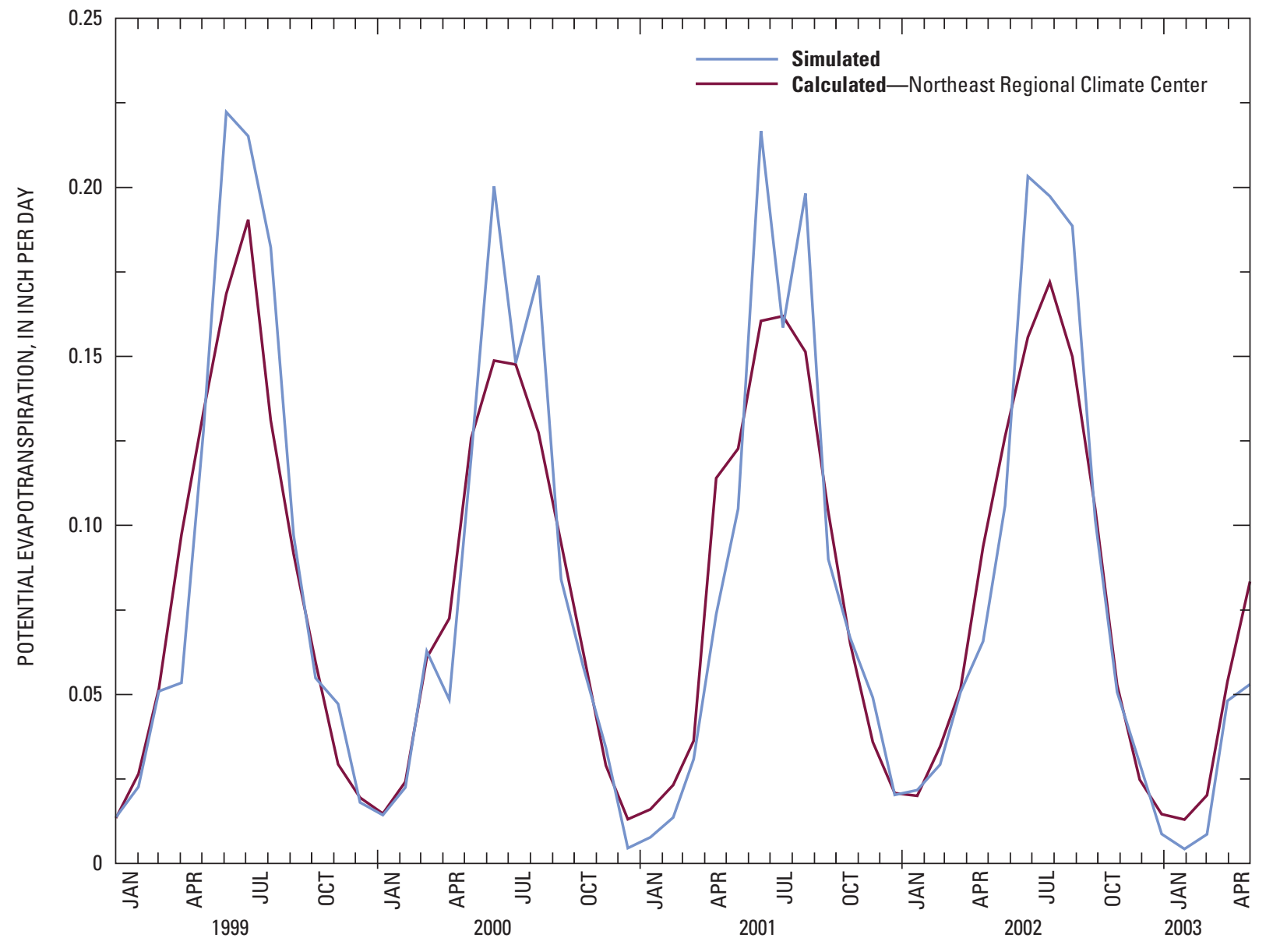

Figure 11. Relation between potential evapotranspiration (PET) estimated from the Precipitation Runoff Modeling System and by the Northeast Regional Climate Center and averaged for four weather stations reporting hourly for the period January 1, 1999, to April 30, 2003, near the Pomperaug River watershed, Connecticut. 
of which are defined by general relations developed by Viger and others (1998). PRMS assumes that all the intercepted precipitation is eventually evaporated. The cover type and density associated with each HRU for summer and winter conditions are shown on figure 10 .

\section{Soil-Moisture Balance}

The soil-moisture balance module in PRMS controls the rate of AET and recharge to the subsurface and groundwater reservoirs. The available soil moisture is controlled by the soil type, precipitation, and PET, with the option to directly route available water to the groundwater reservoir. The soil type determines the field capacity and maximum water content of the soil, which is determined from National Resource Conservation Service (NRCS) soil coverages for the watershed (Viger and others, 1998). The module operation is summarized below:

- Water is removed from the soil reservoir by evapotranspiration.

- Any remaining water is routed either to the subsurface reservoir or the groundwater reservoir depending on the local geology. In areas of coarse glacial stratified deposits, excess soil water is routed directly to the groundwater reservoir; thus, in these areas there is no intermediate subsurface reservoir. In areas of till and bedrock, excess soil water is routed to the subsurface reservoir.

The simulated long-term AET is approximately 65 percent of the simulated annual PET, which is consistent with the 64 percent estimated by Meinzer and Stearns (1929).

\section{Runoff}

Three PRMS modules control the magnitude and distribution of water flow from the land surface, subsurface, and groundwater reservoirs. These include surface runoff, subsurface storage and runoff, and groundwater storage and runoff. As previously discussed, the climate and soil modules control the long-term water balance. The runoff modules control the rate and timing of runoff and, therefore, control the discharge magnitude and shape of the daily hydrograph. The parameter descriptions and method of determination of their values for the three runoff/flow modules are described below.

\section{Surface Runoff}

The percent surface-runoff contribution to total flow cannot be estimated from the hydrograph because of the difficulty in separating this runoff component from rapid subsurface runoff. However, the physical basis for this process can be defined within reasonable limits so that the PRMS surface-runoff function can be parameterized on the basis of measurable watershed quantities. PRMS determines the surface runoff by assuming direct contribution from open water and wetlands, defined variable-source contributing areas, and impervious areas. Therefore, surface runoff is controlled by the rate of runoff from variable-source contributing areas and the amount of impervious surface in each HRU. The variable-source contributing areas are those areas near streams and wetlands that are considered to behave as impervious surfaces once they become saturated during precipitation events.

\section{Surface Runoff Generated from Variable-Source Areas}

Variable-source areas are assumed to be present near streams and wetlands, and the maximum extent is equivalent to the area of Hydrologic Class D soils in each HRU (see fig. 7). The hydrologic soil class is defined in NRCS Soil Survey reports as those soils that have a high runoffproducing potential due to poor drainage either because of low permeability, high water table, or shallow impermeable layer such as hard-pan or bedrock (U.S. Department of Agriculture, Natural Resources Conservation Service, 2004).

The rate of growth of the variable-source area is defined by:

$$
\text { ca } \_ \text {percent }=\text { smdix_coef* } 10^{[\text {smidx_exp*smdix] }} \text {, }
$$

where

ca_percent is the percentage of an HRU that comprises the variable-source contributing area, smdix_coef is the area of surface water, smdix exp is determined from drainage density, and smdix is the soil-moisture index calculated by PRMS.

A maximum ca_percent is defined (carea_max), thus limiting the directly contributing area for each HRU. As an initial assumption, carea max is assumed to be the area of water bodies plus the area of hydrologic soil class D in each HRU.

The smdix_coeff surface-runoff routing coefficient represents the minimum value (intercept) of the logarithmic relation between percent contributing area and available moisture (values range from 0.0001 to 1.0 ). The value of this parameter was set equal to the area of surface water in each HRU; when smdix is zero or very low, the contributing area would consist, at a minimum, of the surface-water bodies themselves.

The smdix_exp surface-runoff routing coefficient represents the rate at which the contributing area increases towards its maximum value (carea max) (values range from 0.2 to 0.8 ). The value reflects the HRU slope and surface conditions - low values on low slopes with higher storage potential and high values on high slopes with less storage potential. The initial value was assumed to be directly related to the drainage density of the HRU (fig. 6). This assumption is based on the consideration that higher drainage densities typically occur in steeper headwater areas and that the drainage density reflects the surface conditions most favorable to runoff generation. 
Because the range of smidx_exp is small $(0.2$ to 0.8$)$ and the potential range of drainage density is logarithmic, the general relation with the drainage density is developed assuming that smidx_exp is a logarithmic function of drainage density so that higher values of drainage density are correlated to higher smidx_exp values, and vice versa. The relation is developed on the basis of a "typical" drainage density (defined as $\mathrm{D}_{\mathrm{d}}=\Sigma \mathrm{L} / \mathrm{A}$ ) function defined from the total drainage length ( $\mathrm{L}$, in miles) to the watershed area (A, in square miles) (Leopold and others, 1964):

$$
\mathrm{L}=1.4^{*} \mathrm{~A}^{0.60},
$$

Re-arranging equation 7 in terms of drainage density gives:

$$
\mathrm{D}_{\mathrm{d}}=1.75 / \mathrm{L}^{0.67},
$$

And relating $\mathrm{D}_{\mathrm{d}}$ directly to smidx_exp gives:

$$
\text { smidx_exp }=c^{*}\left(D_{d}\right)^{x} \text {. }
$$

where $\mathrm{c}$ and $\mathrm{X}$ are model-defined fitting parameters.

Using the range of stream lengths in each HRU, the equation can be solved for $\mathrm{c}$ in the range of smidx_exp from 0.8 to 0.2 . For the HRU distribution in the Pomperaug River watershed, an approximate value for $\mathrm{c}$ is 0.5 and $\mathrm{X}$ is 0.4 . Values of stream length greater than $100 \mathrm{mi}$ would result in smidx_exp $=0.2$ and values less than $1 \mathrm{mi}$ would result in smidx_exp $=0.8$. (This relation is designed to give reasonable initial values for this parameter.)

\section{Surface Runoff Generated from Impervious Surfaces}

Impervious surfaces are those areas that generate direct precipitation runoff. The fraction of observed impervious surfaces associated with pavement, rooftops, and other nonporous surfaces is a function of how well the direct runoff is collected and transported to the stream. As such, the degree of stormwater control and retention is an important element in estimating the effective impervious area that the model uses to route precipitation directly to the stream.

The direct surface runoff from impervious surfaces is computed as the precipitation minus depression storage over these surfaces. On the basis of the watershed conditions, the impervious-surface depression storage is set at 0.001 . The fraction of effective impervious area in an HRU ranges from 0.0 to 1.0 and is assumed to be a log-function of the percent urbanization within the HRU. This assumes that as urbanization increases, the connectedness of the impervious areas and the likelihood for drainage features (storm sewers, ditches, etc.) are also increased.

The PRMS model, in the daily time step computational mode, assumes that runoff from impervious surfaces is routed directly to streamflow after accounting for impervious-surface depression storage. Thus, the fraction of impervious surface assigned to each HRU, times the rainfall and snowmelt computed for each HRU, contributes directly to the volume of surface runoff to the stream for the day. In urban areas with stormwater-conveyance systems, the total impervious area represented by pavement and rooftops would provide the necessary data to define the percent impervious area for each HRU in PRMS. However, in less-developed areas, the total impervious surface would not necessarily represent the total area contributing directly to runoff. This is because runoff generated on impervious surfaces may not be routed directly to streams but would instead be routed to grassed or wooded areas where some or all of it would infiltrate. Because of this, the total impervious area in an HRU is converted to an effective impervious surface for different categories of land use.

The actual percent impervious surface area provides the basis from which the parameter for effective impervious area can be estimated. The relation between effective impervious area and land-use category is developed from land-use/runoff data available for the Pomperaug River and its tributaries as well as other available data. The total impervious area does not include areas of water (lake, pond, and stream surfaces). The direct precipitation on water surfaces is taken into account as part of the srunoff_smidx module previously discussed. The relation between land use and impervious surface would take the following form:

(Total impervious area, in percent $)=$ $\Sigma\left(\mathrm{c}_{\mathrm{i}}^{*}(\text { land use, in percent })_{\mathrm{i}}\right)$,

where
c is the assumed percent impervious for each land-use category, and
i is summed within each HRU.

This relation has been developed for the state of Connecticut (Prisloe and others, 2002) on the basis of LANDSAT satellite imagery (fig. 9).

The total estimated effective impervious area (EIA) for each HRU (as a fraction) would then be determined as a function of the estimated total impervious area (TIA) computed by an assumed connectedness relation with the following general form:

$$
(\mathrm{EIA})=\mathrm{k}_{1} *(\mathrm{TIA})^{\mathrm{N}}
$$

where

$$
\begin{aligned}
& \mathrm{k}_{1} \quad \text { is the intercept of the log regression, and } \\
& \mathrm{N} \text { is the slope of the log regression. }
\end{aligned}
$$

The values for $\mathrm{k}_{1}$ and $\mathrm{N}$ from the literature (Alley and Veenhuis, 1983) are often assumed to be 0.15 and 1.41, respectively, for a "typical" region in the United States with storm sewers in place.

Equation 11 is modified for Connecticut using streamflow and precipitation data for the State. Assuming that the runoff from impervious surfaces enters the stream directly within the daily time step of the model, direct runoff from impervious 
surfaces is assumed to be occurring during periods where the hydrograph rises and falls within a single day in response to a single storm event. Additionally, the potential effect of ice and snow accumulation were avoided by analyzing runoff only during the late spring, summer, and early fall. The storm runoff analysis is thus constrained to include single-day storms with concurrent runoff occurring from April through October during a period of streamflow recession. An additional constraint limits the storms analyzed to $0.5 \mathrm{in}$. of rainfall or less in order to avoid potential issues associated with runoff generation from increasing ground saturation (Zarriello and Barlow, 2002; Zarriello and Ries, 2000).

The runoff analysis described above used 18 watersheds in Connecticut representing the range of land-use and impervious-surface percentages in the State. The selected watersheds included only those with areas comparable to or smaller than the Pomperaug River (ranging in area from 4 to $75 \mathrm{mi}^{2}$ ) so that attenuation of surface runoff due to scale effects would be of the same order of magnitude as would be expected for watersheds of the size of the Pomperaug, Weekeepeemee, and Nonnewaug Rivers. Within the range of watersheds used in the analysis, no relation was found between the ratio of EIA to TIA and the size of the watershed. This indicates that at the scale of interest, the estimated EIA is independent of the watershed size.

Two years of recent streamflow record were analyzed for each of the watersheds. Suitable runoff events were isolated from the records and correlated with precipitation records from nearby NOAA weather stations.

The pool of weather stations used for the analysis included 12 stations with continuous record. From one to three stations were used to represent the precipitation for each of the watersheds depending on proximity of the stations to the watershed of interest. Where multiple stations were used, the values from each station were averaged. Thus, the analysis does not attempt to evaluate the spatial distribution of precipitation as it relates to the watersheds of interest. Instead, the large number of events extracted from the data is assumed to average out the errors associated with the use of potentially nonrepresentative weather stations.

The results of the runoff analysis are provided on table 4 with a general description of the development status of the watershed. In general, the percent total impervious area for the Connecticut watersheds was low compared to the data from Alley and Veenhuis (1983). For this reason, the Alley and Veenhuis data were combined with the Connecticut data in order to provide a data set appropriate for use in areas that are partly urban and partly rural (herein referred to as the Connecticut modified data set). In addition, an assumed value for EIA when EIA is 100 percent was included. It was found that the data shown on table 4 fit a polynomial model better than a power function, indicated by equation 11 . Because there does not appear to be any specific physical reasoning behind the form of the model, the polynomial form is assumed to be similarly appropriate. The modified EIA estimation model for Connecticut determined from the data on table 4 is given as:

$$
(\mathrm{EIA})=0.008 *(\mathrm{TIA})^{2}+0.191 *(\text { TIA })
$$

for the Connecticut and Alley and Veenhuis data (Connecticut modified), and

$$
(\text { EIA })=0.00013 *(\text { TIA })^{3}+0.005 *(\text { TIA })^{2}+0.2287 *(\text { TIA })
$$

for the Connecticut data only. This latter equation is considered the most appropriate for the Pomperaug River watershed because it is rural.

The increase in EIA with increasing percent impervious surface for three different data sets is shown on figure 12 . The curve for the Alley and Veenhuis (1983) data (green line) is representative of urban areas in and around Denver, Colo. These data show a steeper rate of increase of EIA in response to TIA than the Connecticut data (blue line). This difference is likely because of the larger and more rural nature of the watersheds used to develop the Connecticut data. The Connecticut modified curve (red line) is a composite of the two data sets and could be used in areas of Connecticut that are transitioning from rural to urban settings. The blue curve is the most appropriate for use in the Pomperaug River watershed because of the generally low density of impervious area in the watershed and for all the HRUs in the model.

The data on figure 12 indicate that a family of curves describing rural to urban settings (reflective of imperviousarea density) may be an appropriate way to characterize the TIA/EIA relation for different hydrologic conditions. However, these curves also may be modified on the basis of a specific knowledge of the existence and effectiveness of storm drains and impervious connectedness to convey rainfall runoff directly to water bodies. Estimates of EIA derived from equation 13 are comparable to an equation proposed by Sutherland (2000) for somewhat disconnected watersheds with some infiltration measures over the range of impervioussurface percentages found in the Pomperaug River watershed.

\section{Subsurface Runoff}

The subsurface-runoff component of the total streamflow is not easily determined because the mechanisms by which it occurs may be highly variable and not necessarily a function of general watershed characteristics. For this reason, the subsurface-runoff contribution is calculated from equation 4 once groundwater and surface runoff are estimated. Because groundwater discharge equals groundwater recharge, the longterm recharge is fixed by the estimate of long-term groundwater runoff. The values of the subsurface parameters are optimized once the parameters for groundwater and surface runoff are estimated.

The Rosenbrock optimization routine in PRMS (Rosenbrock, 1960; Leavesley and others, 1996) was used to determine the two key subsurface-runoff parameters that route water vertically (recharge to groundwater) and horizontally (rapid subsurface runoff). The optimization was accomplished for the watershed as a whole, assuming a single subsurface 
Table 4. Impervious-surface data used for Connecticut runoff analysis.

[USGS, U.S. Geological Survey; $\mathrm{mi}^{2}$, square miles; na, not applicable]

\begin{tabular}{|c|c|c|c|c|c|c|}
\hline River/streamgage name & $\begin{array}{c}\text { USGS } \\
\text { streamgage } \\
\text { identification } \\
\text { number }\end{array}$ & $\begin{array}{l}\text { Actual } \\
\text { impervious } \\
\text { surface } \\
\text { (percent) }\end{array}$ & $\begin{array}{l}\text { Percent } \\
\text { water }\end{array}$ & $\begin{array}{l}\text { Effective } \\
\text { impervious } \\
\text { surface } \\
\text { (percent) }\end{array}$ & $\begin{array}{c}\text { Watershed } \\
\text { area } \\
\left(\mathrm{mi}^{2}\right)\end{array}$ & Development status \\
\hline Whitford Brook near Old Mystic & 01118668 & 3.64 & 2.30 & 0.9 & 12.0 & Rural no controls \\
\hline Mount Hope River near Warrenville & 01121000 & 2.82 & 1.98 & 1.4 & 28.6 & Minor regulation \\
\hline Stony Brook near Suffield & 01184100 & 4.24 & 0.85 & 0.8 & 10.4 & Rural no controls \\
\hline Burlington Brook near Burlington & 01188000 & 3.41 & 0.71 & 1.8 & 4.10 & Minor regulation \\
\hline Hockanum River near East Hartford & 01192500 & 12.4 & 2.16 & 2.2 & 73.4 & $\begin{array}{l}\text { Urban stormwater } \\
\text { collection and } \\
\text { minor regulation }\end{array}$ \\
\hline Indian River near Clinton & 01195100 & 4.30 & 0.37 & 0.1 & 5.70 & Rural no controls \\
\hline Quinnipiac River at Southington & 01195490 & 18.0 & 1.14 & 2.6 & 17.4 & Minor stormwater \\
\hline Mill River near Hamden & 01196620 & 8.73 & 0.55 & 1.1 & 24.5 & Rural no controls \\
\hline Still River at Brookfield & 01201487 & 12.8 & 2.72 & 1.7 & 62.3 & $\begin{array}{l}\text { Minor stormwater } \\
\text { and regulation }\end{array}$ \\
\hline Pomperaug River at Southbury & 01204000 & 3.84 & 1.29 & 1.1 & 75.1 & Minor regulation \\
\hline Rooster River at Fairfield & 01208873 & 27.7 & 1.06 & 5.6 & 10.6 & $\begin{array}{l}\text { Urban stormwater } \\
\text { collection }\end{array}$ \\
\hline Data from Alley and Veenhuis (1983) & na & 26 & 0 & 15 & & na \\
\hline Data from Alley and Veenhuis (1983) & na & 15 & 0 & 8.5 & & na \\
\hline Data from Alley and Veenhuis (1983) & na & 60 & 0 & 42 & & na \\
\hline Data from Alley and Veenhuis (1983) & na & 88 & 0 & 83 & & na \\
\hline Assumed & na & 100 & 0 & 95 & & na \\
\hline Average for Connecticut watersheds & & 7.63 & 1.43 & 1.6 & & \\
\hline
\end{tabular}




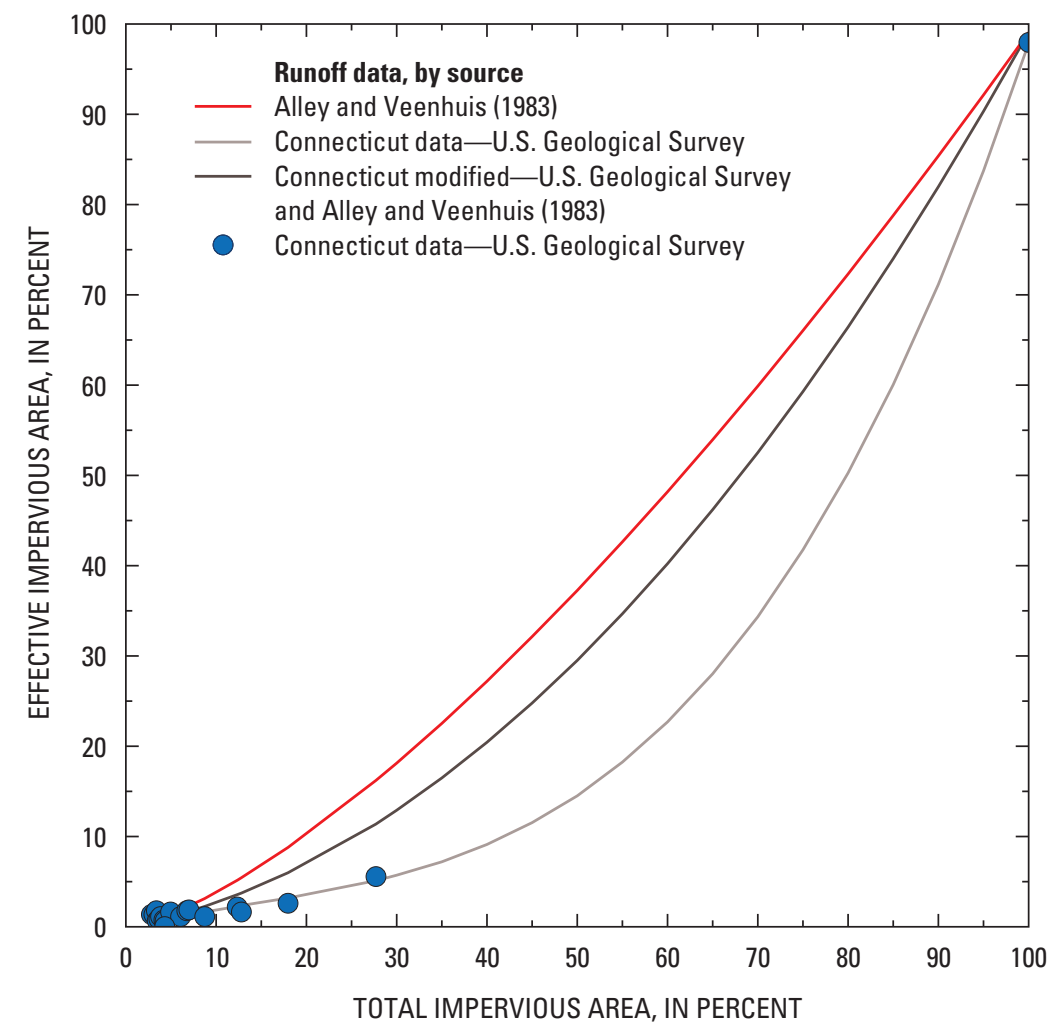

Figure 12. Relation between total impervious area in the watershed [as mapped by Prisloe and others (2002)] and effective impervious area as used in the Precipitation Runoff Modeling System model for three different data sets, Pomperaug River watershed, Connecticut. reservoir, and then distributed to each HRU on the basis of the specific physical characteristics of each HRU.

The subsurface reservoir represents areas of rapid nontraditional groundwater flow (not an extensive aquifer) often occurring as shallow perched groundwater zones:

- overlying the interface between till and bedrock,

- existing as sand lenses, and

- existing as secondary porosity below and within the root zone.

The reservoir is assumed to behave in a linear manner with vertical and horizontal outflow components driven by the total water stored within it. Thus, the vertical and horizontal routing coefficients are defined as

$$
\begin{gathered}
\text { Vertical flow }=\text { ssr2gw_rate(ssres_stor) } \\
\text { Horizontal flow }=\text { ssrcoef_lin(ssres_stor) }
\end{gathered}
$$

where

ssr2gw_rate and ssrcoef_lin are the vertical and horizontal routing coefficients, respectively, and ssres_stor is the total water volume stored in the reservoir (in inches).

The initial magnitude of the calibrated parameters ssr2gw_rate and ssrcoef_lin is determined by optimization using the Rosenbrock module (Leavesley and others, 1996) and distributed to each HRU on the basis of percent coarse glacial stratified deposits, assuming that this is an indication of the presence of non-traditional groundwater flow paths.

The ssr2gw_rate routing coefficient ranges from 0 to 1 and its spatial variability is assumed to be a function of the subsurface conditions in each HRU. As an initial assumption, this value is approximated by the percent coarse glacial stratified deposits in each HRU, with a nominal value even if there is no occurrence of coarse glacial stratified deposits. Thus, vertical infiltration will generally only occur in areas of coarse glacial stratified deposits.

The ssrcoef_lin routing coefficient also ranges from 0 to 1 and is assumed to be a function of surficial geology, so that the horizontal to vertical flow preference is determined as a function of the percent glacial stratified deposits in the HRU. Where there are more coarse glacial stratified deposits, vertical movement is favored and vice versa. Additionally, the surface slope will influence the rate of horizontal flow out of the reservoir and, therefore, the value of the parameter. Because this parameter sets the rate of horizontal flow from the 
subsurface reservoir, it is assumed to be equal to the inverse of the percent coarse glacial stratified deposits (allowing for a nominal value even where there is 100 percent coarse glacial stratified deposits) and the relative slope of the HRU (HRU slope relative to the mean slope of all the HRUs).

\section{Groundwater Flow}

In the Pomperaug River watershed, previous studies on groundwater contribution to streamflow have generally concluded that the long-term contribution from groundwater is approximately 60 percent (see previous sections). Thus, the long-term simulated groundwater recharge should be approximately 60 percent of the observed total runoff (streamflow) at the streamgage. The two generalized aquifer types, one comprised of till and bedrock (identified by the subscript till), and the other coarse glacial stratified deposits (identified by the subscript cs) are characterized as having the following values for transmissivity (T) and storativity (S) on the basis of work by Starn (J.J. Starn, U.S. Geological Survey, oral commun., 2004):

$$
\begin{aligned}
\mathrm{T}_{\mathrm{cs}} & =\begin{array}{l}
10,000 \mathrm{ft}^{2} / \mathrm{d} \text { for coarse glacial stratified } \\
\text { deposits, }
\end{array} \\
\mathrm{T}_{\text {till }}= & 200 \mathrm{ft}^{2} / \mathrm{d} \text { for till/bedrock, } \\
\mathrm{S}_{\mathrm{cs}}= & 0.2 \mathrm{for} \text { coarse glacial stratified deposits, and } \\
\mathrm{S}_{\text {till }}= & 0.01 \text { for till/bedrock. }
\end{aligned}
$$

Each HRU has a percentage of both aquifer types, and the representative value for the hydraulic variables for each HRU is computed as the area-weighted harmonic mean.

The groundwater runoff is simulated as a linear reservoir. Recharge to the reservoir occurs from the subsurface reservoir controlled by the vertical subsurface-runoff coefficient and by direct recharge from the soil zone. Physically based estimates of the groundwater-reservoir routing coefficient for each HRU are developed in order to provide the spatial and temporal distribution of groundwater runoff in the watershed. The following linear reservoir equation controls groundwater runoff from the groundwater reservoir in PRMS:

$$
\text { gwflow }=(\text { gwflow_coef }) *(\text { gwres_stor }) \text {. }
$$

The gwflow_coef coefficient sets the linear groundwaterrunoff rate from the groundwater reservoir (gwres_stor) for each HRU. The coefficient ranges from 0 to 1 ; a high value represents highly conductive reservoir materials, and a low value represents poorly conductive materials. Equation 16 is updated each time step of the model and can thus be formulated as a linear differential equation:

$$
\text { gwflow }=\delta \mathrm{h} / \delta \mathrm{t}=\mathrm{k} *(\mathrm{H})
$$

where

$\mathrm{h} \quad$ is the flow depth per day from the reservoir with total storage $\mathrm{H}$,

$\mathrm{k}$ is a routing coefficient, $\delta \mathrm{h}$ is the change in head, and
$\delta \mathrm{t}$ is the change in time.

The solution to this equation is

$$
\mathrm{k} * \mathrm{t}=\ln (\mathrm{H})
$$

where $t$ is elapsed time.

Equation 18 indicates that gwflow_coef is a linear reservoir decay coefficient. The value of gwflow_coef can therefore be conceptualized as the base-flow recession coefficient for a stream hydrograph, where the source reservoir is the PRMS groundwater reservoir. As developed by Halford and Mayer (2000), the base-flow decay over time period $t$ is given as:

$$
\mathrm{Q}=\mathrm{Q}_{0} * \exp \left(\frac{-\pi^{2} * \mathrm{~T} * t}{4 * \mathrm{~L}^{2} * \mathrm{~S}}\right)
$$

where

Q is the flow after time $t$ has elapsed,

$\mathrm{Q}_{0} \quad$ is the initial flow,

$\mathrm{T}$ is the representative transmissivity of the HRU,

S is the representative storativity of the HRU, and

L is the groundwater flow length.

Assuming $\mathrm{Q}$ and $\mathrm{Q}_{0}$ to be equivalent to reservoir storage, $\mathrm{h}$, and $t$ (the time step) $=1$ day, equation 19 can be considered as a corollary to equation 17 where the decay coefficient $\mathrm{k}$ is equal to

$$
\exp \left(\frac{-\pi^{2} * \mathrm{~T} * t}{4 * \mathrm{~L}^{2} * \mathrm{~S}}\right)
$$

Because equation 17 is updated for each time step and computes the outflow from the reservoir depth rather than the reservoir depth after the elapsed time, the value for gwflow_coef is equivalent to $1-\mathrm{k}$. This is shown by assuming that the reservoir head, $\mathrm{H}$, is equal to the head during the previous time step times $\mathrm{k}$. Thus, the updated reservoir head is given by:

$$
\mathrm{H}_{\mathrm{i}}+1=\mathrm{k}^{*} \mathrm{H}_{\mathrm{i}} .
$$

The updated reservoir head is also calculated as the difference between the initial reservoir head minus the outflow over the time step $\left(\mathrm{h}_{\mathrm{i}}\right)$, thus:

$$
\mathrm{H}_{\mathrm{i}}+1=\mathrm{Hi}-\mathrm{h}_{\mathrm{i}}
$$

Equating these two relations and re-arranging gives:

$$
\mathrm{h}_{\mathrm{i}}=\mathrm{H}_{\mathrm{i}}^{*}(1-\mathrm{k})
$$


which shows that over each time step, $\mathrm{i}$, the outflow rate $(\mathrm{h})$ is determined from the beginning reservoir head $(\mathrm{H})$ times $(1-\mathrm{k})$.

The flow length $\mathrm{L}$ in equation 19 is computed as half of the average distance to a discharge point (stream channel), which is determined as the inverse of the drainage density for each HRU. The values of $\mathrm{T}$ and $\mathrm{S}$ are determined as the areaweighted average values for each HRU.

Although a finite difference groundwater model (MODFLOW-2000) (Harbaugh and others, 2000) is used to determine the simulated groundwater flow (Starn and Brown, 2007), parameterizing it effectively in PRMS is important so that the recharge estimates generated by PRMS reflect the expected groundwater conditions.

\section{Channel Routing}

The ratio of the daily mean streamflow in the Pomperaug River at Southbury and tributary streamflow measured at the continuous streamgages on the Weekeepeemee River and the Nonnewaug River is variable and indicates that spatial and temporal timing and quantity of tributary flow results from variability of hydrologic conditions within the watershed. However, some of the variability observed could be caused by the time lag between flows at upstream locations and those at the downstream location. For example, the lag time between a high flow at the Nonnewaug streamgage and a high flow at the Pomperaug streamgage for a given storm event may be sufficiently long that the daily peaks would not occur on the same day. If this happened, the accumulation of flow in a downstream direction would have to consider flow timing (channel routing), which currently is not part of the model simulation. To evaluate this possibility, the instream traveltime for water to move through the stream network was assessed from 15-minute hydrographs from the Weekeepeemee, Nonnewaug, and Pomperaug streamgages for numerous short-duration high-flow events. The 15-minute hydrographs for a short period of record during which a rapid rise and fall of streamflow was observed at each streamgage are shown on figure 13 . The analysis shows that the lag time is typically less than 4 hours and indicates that the use of a daily time step for the model simulations should not introduce major errors due to flow timing and channel-routing effects. It should be noted, however, that this lag time could happen over 2 days.

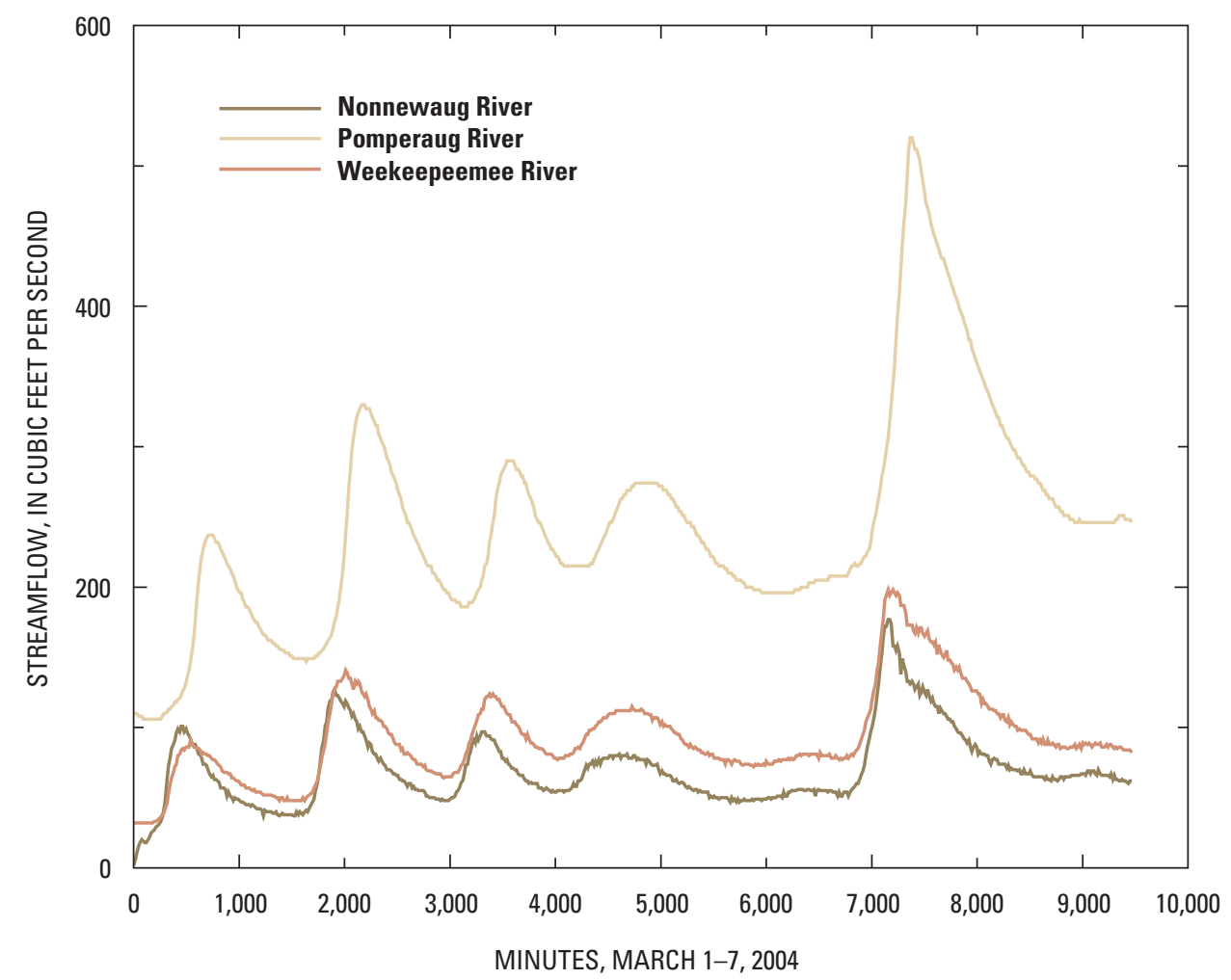

Figure 13. The continuous response (in minutes) of flow events in the Nonnewaug, Weekeepeemee, and Pomperaug Rivers streamgages, Connecticut, March 1 to 7, 2004. 
To verify these observations, the Muskingum (Maidment, 1993) and Convex channel-routing methods (Dingman, 2002) were used to route streamflow from two 24-hour, 15-minute time step hydrographs at the Nonnewaug and Weekeepeemee streamgages to the Pomperaug streamgage. The analysis found that the traveltime between these stations and the Pomperaug streamgage varied from 2 to 4 hours, similar to the analysis of the hydrographs.

With the exception of the Bronson-Lockwood Reservoir and several abandoned quarry ponds near the Pomperaug River in the lower portion of Woodbury, surface-storage reservoirs are not considered to have a major effect on streamflows. The Bronson-Lockwood Reservoir is important only in that the Watertown Fire District periodically releases water from the reservoir above the normal throughflow (natural flow going into and out of the reservoir) to augment flow in the Nonnewaug River when it is needed (Michael Taunis, Operations Manager Watertown Fire District, oral commun., 2005, see following section).
The quarry ponds affect peak flows in the Pomperaug River at Southbury by diverting high flows out of the stream into the pond system, thus attenuating flood peaks. This effect is shown on the stage hydrographs (fig. 14) for the flood of March 29, 2005, at the Weekeepeemee, Nonnewaug, and Pomperaug River streamgages. The figure shows that the peak observed at the two upstream streamgages is cutoff by the time the flow reaches the downstream Pomperaug streamgage. The observations at the Pomperaug streamgage clearly show the effect of storage in the quarry ponds on flow when the river overtops a section of its bank adjacent to the ponds (figs. 15 and 16). The low berm that separates the overflow channel connecting the ponds from the Pomperaug River is only a few feet across and appears to be continuing to erode, raising the possibility that the river may flow into the ponds more frequently or at lower stages in the future. It is not clear when this phenomenon became important hydraulically, but it appears to have been occurring since the mid-1990s.

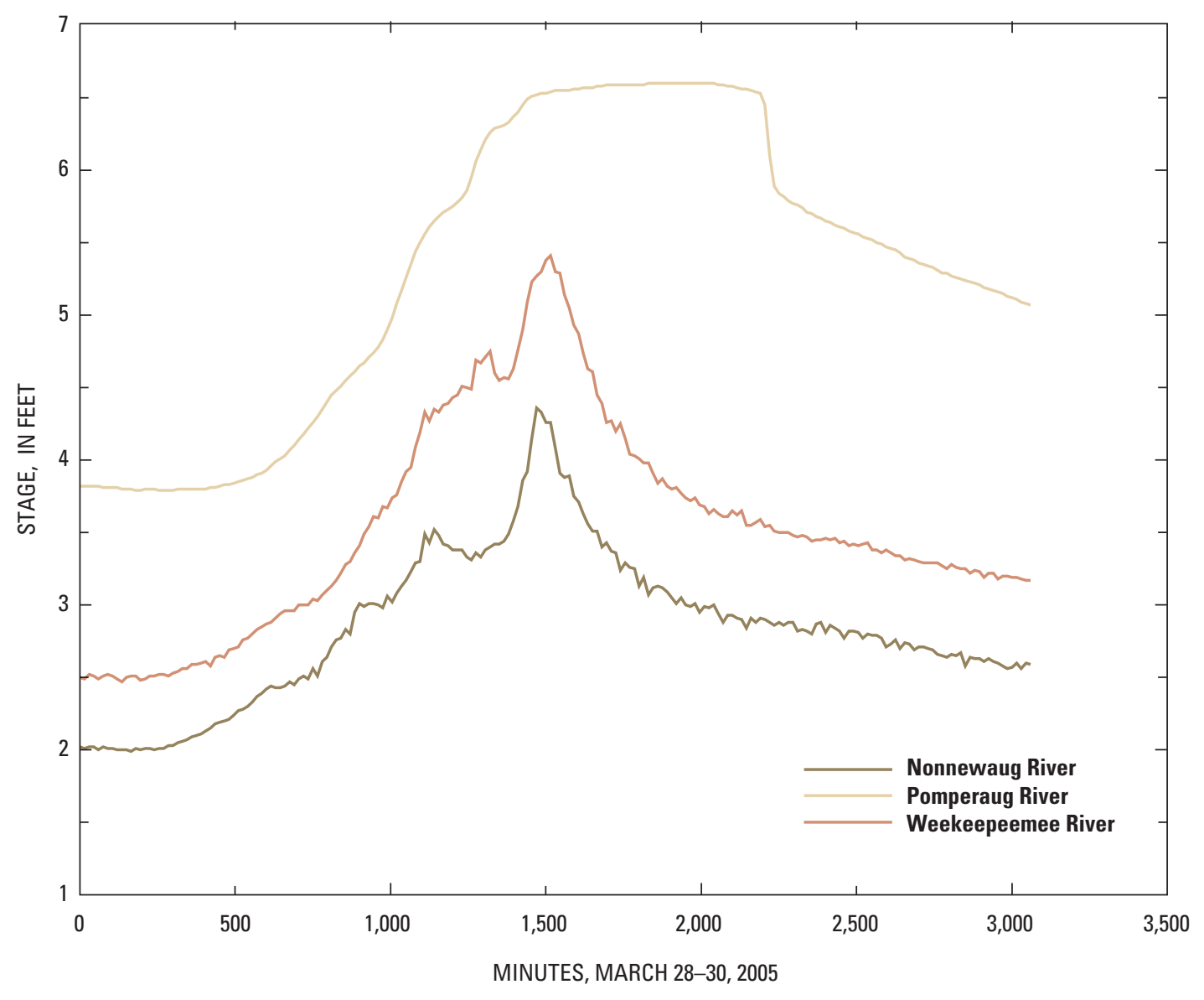

Figure 14. Stage for the Pomperaug, Weekeepeemee, and Nonnewaug Rivers, Connecticut, during the flood event of March 29, 2005, showing the effect of storage at the Pomperaug streamgage. 


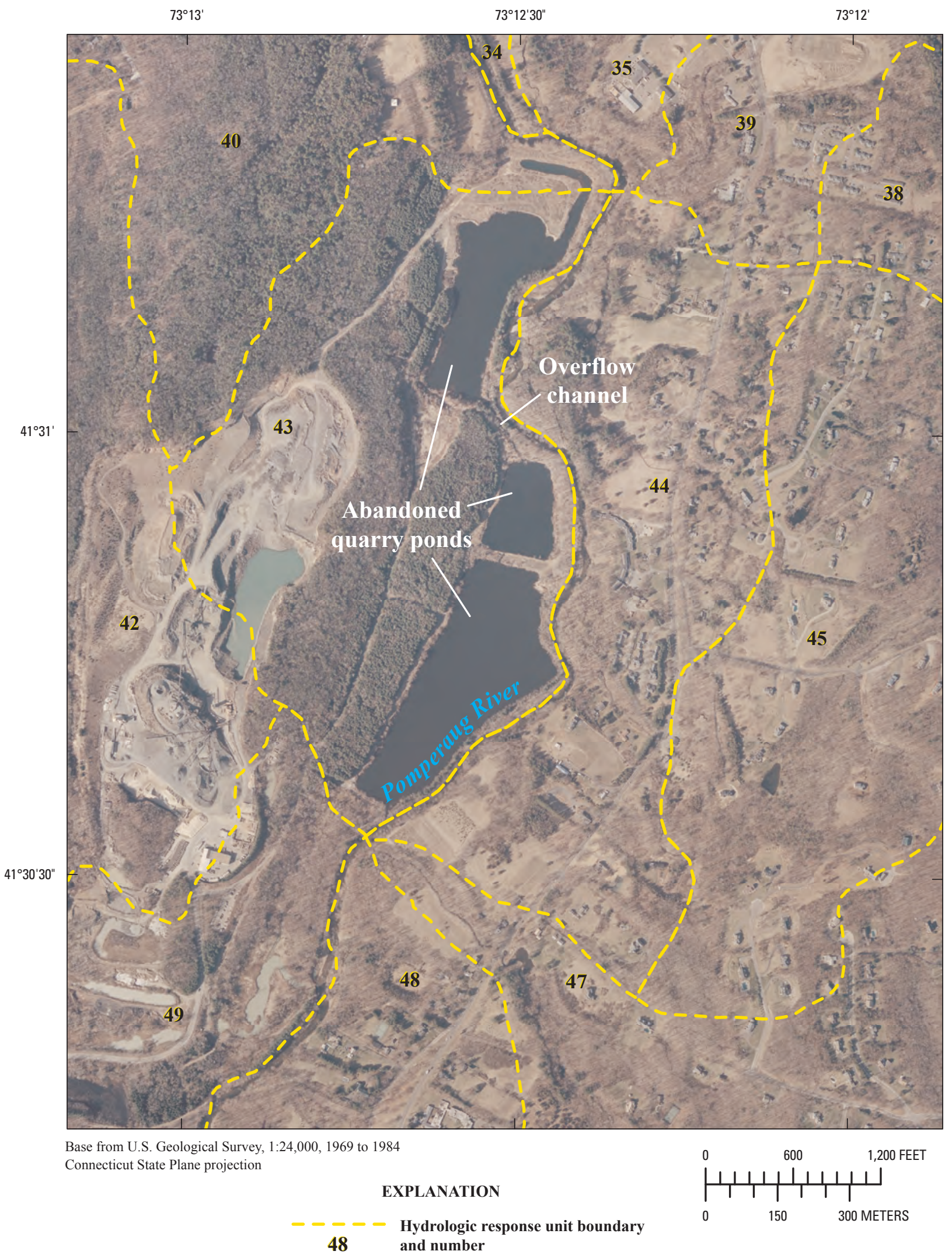

Figure 15. Location of three abandoned quarry ponds and their proximity to the Pomperaug River, Connecticut. 


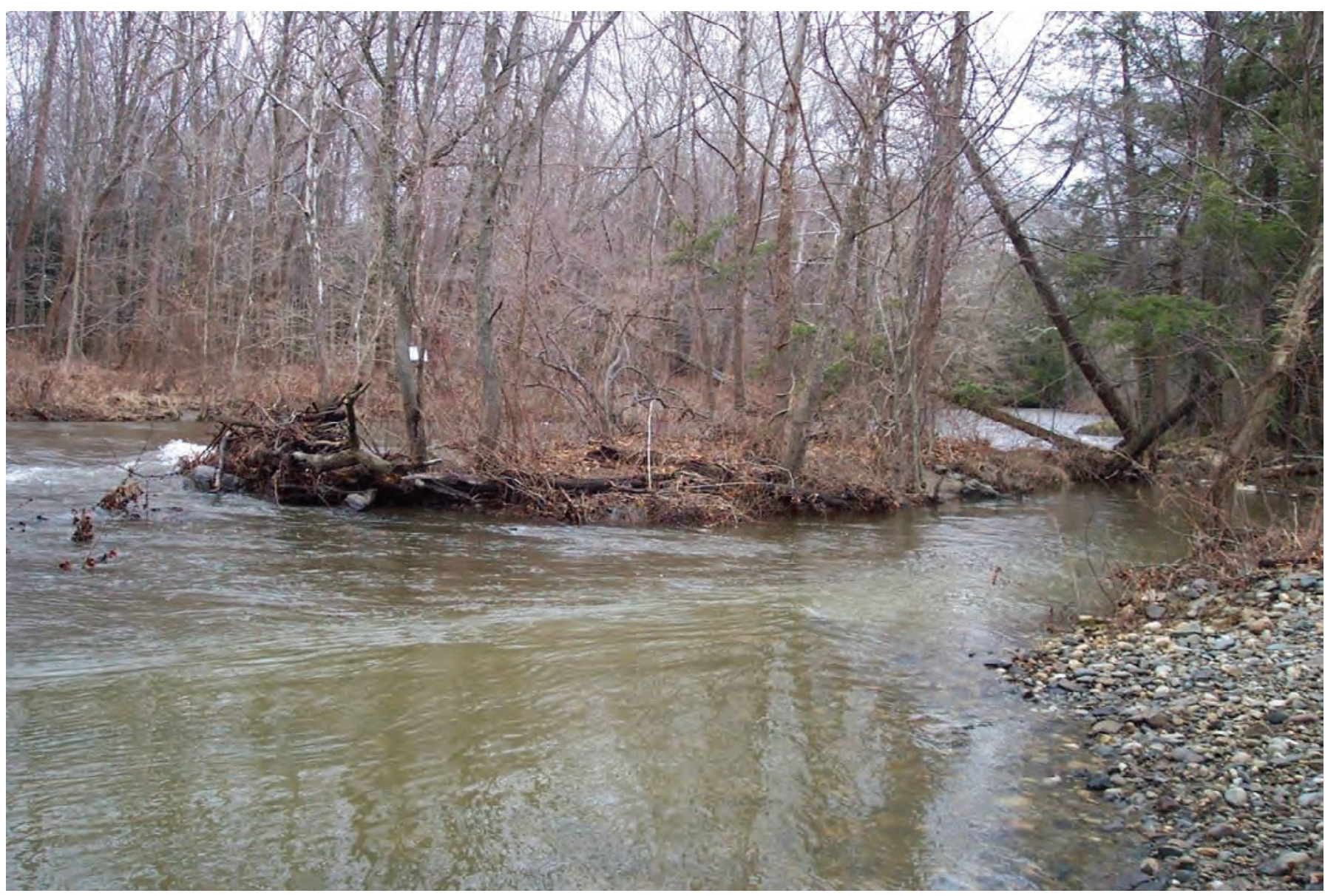

Figure 16. Looking south (downstream) of the high-flow event of March 29, 2005, showing the Pomperaug River, Connecticut, on the extreme left, and overflow into the quarry pond connector stream on the right.

The overflow phenomenon has been observed by operators at the quarry as well as by USGS personnel, and there is abundant post-flood evidence that the river overflows into the pond system at the location of the low berm. In the past, attempts have been made to shore up the berm with rip-rap; however, the phenomenon continues to occur. Observations at the streamgage show that the overflow occurs at a stage of approximately $6.5 \mathrm{ft}$ (fig. 14), which corresponds to a flow at the streamgage of approximately $1,400 \mathrm{ft}^{3} / \mathrm{s}$. Estimates of the hydraulic capacity of the Pomperaug River channel adjacent to the low berm indicate that it would overtop the berm at a streamflow of 800 to $1,000 \mathrm{ft}^{3} / \mathrm{s}$; this is verified by the PRMS model. Additionally, there is a designed overflow at the upstream end of the reach adjacent to the quarry ponds that will overtop at extreme high flows (estimated to be at or near the 20-year flood event).

To account for the overflow and storage phenomenon, the PRMS-generated streamflow tabulated for the reach adjacent to the ponds was adjusted by routing streamflow above
$800 \mathrm{ft}^{3} / \mathrm{s}$ through a linear reservoir, similar to the reservoir routine used in PRMS. After the flow was routed, it was added back to the PRMS-generated hydrograph, thus adjusting the hydrograph for the effect of storage in the quarry ponds. The linear reservoir coefficient was adjusted in the model in order to match the reduction in peak flow between the PRMS simulation and the observed streamflow record.

The stage at which the stream overflows, however, has been variable, which may reflect natural and anthropogenic changes in the condition of the berm. A review of the stage hydrographs over time at the Pomperaug streamgage shows that the condition of the bank separating the river and the overflow channel is dynamic and that the frequent overtopping may be a relatively recent phenomenon. The overflow above $800 \mathrm{ft}^{3} / \mathrm{s}$ is likely not constant in time and cannot be verified as appropriate under all conditions. For this reason, the adjustment of flood peaks to account for the overflow has been applied only to the recent record (1998-2005) and is consid- 
ered to be only an approximate adjustment that illustrates a potential effect.

The return flow from the ponds to the river is through an outlet structure that consists of a concrete broad-crested weir and rip-rap spillway channel. Field observations have confirmed that the outlet structure becomes submerged as the river rises and the ponds fill. In addition, other areas, notably a large wetland downstream from the ponds, become filled during high flows, providing further off-channel storage. The return flow from these other areas may be relatively slow, because there is no observed outlet channel. In summary, a complex hydraulic situation exists in the reach adjacent to the quarry ponds that facilitates diversion of river flow into large offchannel storage areas, notably the abandoned quarry ponds, and this water is returned more slowly to the river through an outlet structure and bank seepage. The effect of the offchannel storage is important and, therefore, has been explicitly modeled and incorporated into the simulation results.

The simple approach to routing flow into and out of the quarry ponds and their associated wetlands, described above, was developed on the basis of a physical representation of the river/pond interaction and outlet structure. Given the true complexity of the situation, however, the routing approach is considered only an approximation designed to provide an appropriate level of peak-flow attenuation. The fillable storage area of the ponds was estimated from topographic maps, and the outlet structure was represented by an 8 -ft wide broadcrested weir. The diversion threshold was assumed to be $800 \mathrm{ft}^{3} / \mathrm{s}$ in the river (as determined by PRMS adjacent to the ponds) above which water is diverted out of the river into the pond/wetland storage. The fraction of water that flows into the ponds and the weir coefficient were treated as arbitrary variables and were determined by modeling judgment.

The routing procedure was accomplished on the daily time step by determining a total inflow to the storage that was translated into a height of stored water. This height was then averaged with the height from the previous time step to obtain an average pond head from which an average outflow rate was estimated. The total daily outflow was then computed, and this volume was subtracted from the storage volume to obtain a new pond height. This procedure was repeated each day until the fillable storage area of the ponds was emptied. PRMS provided the input data to the ponds, and the outflow rate was added back to the hydrograph and combined with downstream runoff also generated by PRMS to reconstruct the hydrograph. The pond/wetland storage has no effect on river flows below the $800 \mathrm{ft}^{3} / \mathrm{s}$ threshold for the reach adjacent to the ponds.

\section{Diversions}

The total water used and derived from the watershed, estimated from public water system records of per-capita water use (table 1), including water from individual domestic wells, is estimated to be $6.4 \mathrm{ft}^{3} / \mathrm{s}$ during the spring and summer months (May, June, July, August, and September) and $5.3 \mathrm{ft}^{3} / \mathrm{s}$ during the fall and winter (October, November, December,
January, February, March, and April). All the water used and derived from within the watershed comes from groundwater sources, except for some local irrigation water pumped from surface-water sources. This source of water use is not documented and is not reported here.

All of the groundwater withdrawals from Watertown Fire District and some of the groundwater withdrawals from Heritage Village are diverted out of the watershed. Tabulation of water use by the three largest public-supply systems shows that during the fall, winter, and early spring months (October through April) approximately $1.4 \mathrm{ft}^{3} / \mathrm{s}$ from the aquifer is diverted out of the watershed on a daily basis $\left(1 \mathrm{ft}^{3} / \mathrm{s}\right.$ from the Watertown Fire District and $0.4 \mathrm{ft}^{3} / \mathrm{s}$ from Heritage Village), and during the late spring and summer months (May through September), the average increases to approximately $2.1 \mathrm{ft}^{3} / \mathrm{s}$ $\left(1.5 \mathrm{ft}^{3} / \mathrm{s}\right.$ from the Watertown Fire District and $0.6 \mathrm{ft}^{3} / \mathrm{s}$ from Heritage Village). During periods of low flow, the Watertown Fire District releases water from the Bronson-Lockwood Reservoir upstream of the well field to maintain flows in the Nonnewaug River and to recharge the well field. On the basis of a review of 6 months of documented releases (January to July 2004; Ernie Coppock, Watertown Fire District, written commun., 2004) and reservoir inflows estimated by adjusting the Nonnewaug streamgage record for watershed drainage area to the reservoir, there appears to be a general balance between reservoir release and reservoir inflow during the period analyzed, and the difference between reservoir release and inflow is greatest during periods of low inflow. Thus, the reservoir operation acts to redistribute flow from high flow to low flow, consistent with the operational goal of the Watertown Fire District. Over the course of time, there is no net gain or loss of water from the reservoir relative to natural inflow; however, the residence time of water in the reservoir has not been determined. Consequently, the yearto-year change in storage within the reservoir and the aquifer around the well field is not documented and is assumed to be sufficient to maintain the out-of-watershed diversion from the well field while maintaining flow-through volumes.

Approximately $1 / 3$ of the water pumped from the Heritage Village well field also is diverted out of the watershed (Pomperaug River Watershed Coalition, 2001). This water is not made up through storage and, therefore, is considered a net loss to the watershed as a whole. Part of the water used by individual homes and public supplies in the watershed is consumptive, defined as that part of water withdrawn that is evaporated, transpired, incorporated into products or crops, consumed by humans or livestock, or otherwise removed from the immediate water environment. Consumptive use is assumed to be 20 percent of water used during the late spring and summer months (Starn and Brown, 2007; Solley and others, 1998) and 15 percent during the fall, winter, and early spring. The PRMS model does not account for the diversions or consumptive use, and therefore, these water losses were accounted for by direct subtraction from the simulated hydrograph, similar to the method of addressing high-flow routing through the quarry ponds. 


\section{Calibration, Objective Functions, and Optimization}

The objective functions for the model provide a measure of the goodness of fit between the simulated and observed streamflow. As previously mentioned, the weather input data (temperature and precipitation) and the GIS data were considered to be true measures after initial quality control and were not subject to calibration or optimization. Similarly, the streamflow data recorded at the Pomperaug, Weekeepeemee, and Nonnewaug River streamgages are considered to be true and are not subject to calibration or optimization. Final calibration was achieved by adjusting parameters that were not previously determined from the water-balance analysis to achieve an acceptable result for the streamflow hydrograph as a function of the total flow volume and the variability of flow.

It is recognized that errors are associated with all the input data sources, and the model results calibrated and optimized to these data are considered to be applicable within the constraints of the input data errors. As a result, and to meet the objective that the model be transferable in time and space, the philosophical approach taken in this study was to optimize and calibrate over the entire record and not over specific time periods or regions of the model to achieve a better fit with the streamflow record. With this in mind, the model parameters are consistent in time and space and are based on the input data so that the model is reasonably transferable to regions and times where similar input data are available.

The Pomperaug River watershed study was concerned with the spatial and temporal (primarily seasonal) accuracy of each simulated component of the hydrograph - including surface runoff, subsurface runoff, and groundwater runoff (base flow) - thus, the objective functions must be suitable for use with each of the components as well as the total streamflow hydrograph at different locations in the watershed. The objective functions include the observed daily flow for the Pomperaug, Nonnewaug, and Weekeepeemee Rivers and the runoff components as a percentage of the mean daily flow. Additionally, the groundwater base flow can serve as an objective function given a consistent analysis that can be used for both the observed and simulated records. The accuracy of the simulated streamflow for the period and statistical distribution of interest is expected to be within the range of accuracy for the same measures as the observed streamflow. In this study, the time frame of interest is the entire period of record and not necessarily any given day, month, or year. The accuracy of the observed streamflow is generally considered to be between 5 and 10 percent of the actual streamflow; thus, over the period and distribution of interest, the simulated streamflow should be within 5 and 10 percent of the observed record with no unexplained bias.

Two input data sets were used to evaluate the model calibration - daily precipitation and maximum/minimum temperature for 1975-1999 developed from 12 NOAA_NWS coop stations in the region (including 1 in the watershedWoodbury) (see fig. 1) and daily precipitation and maximum/ minimum temperature for 1998-2005 developed for 3 automated NOAA climate stations that report hourly data and the Woodbury coop station. The evaluation was focused on statistical similarities between the simulated streamflow data and the observed streamflow from the Pomperaug, Weekeepeemee, and Nonnewaug River streamgages and similarities between the simulated groundwater base flow and the groundwater base flow estimated from the streamgage data. The comparisons were made against the whole simulated record, and parameter calibration was accomplished in a consistent manner for the entire simulated record with less emphasis on specific time periods or individual daily events. This approach minimizes over-calibration to periods of time that may be subject to greater data input uncertainty and provides greater consistency in simulations assuming different land-use conditions. The evaluation was based on five objective functions derived from the observed streamflow at the three streamgages. These functions are:

1. Comparison of the total flow statistics for the calibration periods including the mean and standard deviation of the observed and simulated streamflows.

2. Goodness of fit between the observed and simulated streamflow evaluated using the log-residual or Nash-Sutcliffe statistic.

3. Comparison of the observed and simulated flowduration curves and frequency statistics.

4. Comparison of the magnitude and trends between the observed and simulated ratios of the tributary streamflow (Weekeepeemee and Nonnewaug Rivers) and the streamflow at the Pomperaug River.

5. Comparison of the observed and simulated groundwater contribution to streamflow and baseflow recession characteristics using a consistent base-flow separation program, PART (Rutledge, 1993), and the overall percent groundwater contribution to streamflow.

The model parameterization approach is based on physical reasoning; thus all the parameters are assigned on the basis of the physical characteristics of the watershed or as a function of the input data. For example, the groundwater flow coefficient is determined on the basis of the hydraulic characteristics of the two dominant aquifer system types in the watershedcoarse glacial stratified deposits and till/bedrock materials. Characteristic values for the transmissivity, storativity, and flow-path length are assigned to each HRU on the basis of the percent coarse glacial stratified deposits in the HRU. Similarly, the precipitation and temperature values assigned to each HRU are determined by the xyz spatial relations statistically determined from the available weather-station records.

The final calibration of PRMS was through optimization of the subsurface-runoff routing parameters: ssr2gw_rate, which controls the rate that water leaves the subsurface reservoir vertically to recharge the groundwater reservoir, and 
ssrcoef lin, which controls the rate at which water from the subsurface reservoir leaves horizontally directly to streams. The subsurface reservoir consists of a potentially complex assemblage of unconsolidated materials between the bottom of the soil layer and the top of the groundwater reservoir. The rate of vertical and horizontal leakage out of the subsurface reservoir is inherently difficult to measure and is generally unknown for watersheds in Connecticut. The range of values for these parameters was difficult to determine from the GIS data in the watershed; therefore, the average values of these two parameters were determined from optimization using the PRMS Rosenbrock (1960) optimization routine with the Pomperaug River flow at the Southbury streamgage as the objective function.

Multiple measures of goodness of fit are available in the optimization schemes, including error computed from the untransformed or log-transformed flow data and the absolute or square error. In order to minimize the weight of the largest flows on the optimization (and thus give equal weight to the lowest flows), the log-transformation option was used for this application. The squared error and absolute error options provided similar results; however, the squared error was considered the most appropriate. This is in keeping with the objectives of the study.

The two subsurface parameters, horizontal and vertical, were optimized for 1998-2005, assuming a single subsurface reservoir. Thus, the resulting parameter values represented a watershed average. A parameter value was assigned to each HRU by distributing the values on the basis of the percent coarse glacial stratified deposits and the average slope of each HRU, so that the area-weighted average of all the values equaled the watershed-wide calibrated value.

The distribution functions are defined as:

$$
\text { ssrcoef_lin }=(1-\mathrm{c}) *\left(\mathrm{~S} / \mathrm{S}_{\mathrm{a}}\right) * \mathrm{f}
$$

where

c is the fraction coarse glacial stratified deposits in each HRU;

$\mathrm{S}$ is the HRU slope;

$\mathrm{S}_{\mathrm{a}} \quad$ is the average HRU slope for the watershed; and

$\mathrm{f} \quad$ is an adjustment factor determined by matching the mean value for each HRU with the optimal value for the entire watershed.

and

$$
\mathrm{ssr} 2 \mathrm{gw} \_ \text {rate }=\mathrm{c}+\mathrm{R}-\mathrm{c} * \mathrm{R},
$$

where $\mathrm{R}$ is a nominal recharge adjustment factor.

Both $\mathrm{f}$ (in equation 23) and $\mathrm{R}$ (in equation 24) were determined by matching the mean value for each HRU with the optimal value for the entire watershed. In addition, including
$\mathrm{R}$ in the calculation of the ssr2gw rate prevents any HRU from having zero groundwater recharge.

Equation 23 determined that the horizontal flow from the subsurface reservoir was greatest where there is the least coarse glacial stratified deposits (because in these areas it is assumed that vertical drainage is impeded by till and bedrock) and that high relative slope also increased the horizontal outflow from this reservoir. Equation 24 determined that, if there is no nominal recharge, the rate was simply a function of the fraction coarse glacial stratified deposits. Thus, where there is 100 percent coarse glacial stratified deposits, this rate coefficient is at its maximum. If a nominal value is assumed (to meet the expected mean value from the Rosenbrock single-reservoir optimization), the equation ensures the coefficient value cannot exceed its maximum value of 1 by subtracting $\mathrm{c}^{*} \mathrm{R}$.

\section{Model Results}

The simulated long-term, seasonal, and spatial distribution of runoff was compared with available streamflow records for the Pomperaug River and its two major tributaries, the Weekeepeemee and Nonnewaug Rivers; the simulated and estimated groundwater-runoff components were also compared. Two input data sets were used to generate the simulated daily streamflow time-series records. The first data set included daily precipitation and maximum and minimum air temperature from 12 coop weather stations operated from 1975 to 1999 as part of the daily climatological data series (Northeast Regional Climate Center, 2006) for New England. A second data set of more recent weather data also was compiled using currently operating stations that report precipitation, temperature, wind speed, relative humidity, estimated PET, and other meteorological data. Although both data sets are used for model simulation, the more-recent data set is considered the most important for evaluating model performance and will serve as the baseline data set that can be updated as part of future modeling efforts in the watershed.

\section{Streamflow and Water Balance}

For the period simulated by the model, the ratio of total streamflow to precipitation $(\mathrm{Qt} / \mathrm{P})$ equals 49 percent. This is comparable to the expected value, reported by Meinzer and Stearns (1929) and Wilson and others (1974), suggesting that the long-term simulation of runoff quantity is relatively accurate. The simulated annual runoff totals and the observed streamflow at the Pomperaug River streamgage for water years 1999 through 2005 are shown on table 5 and figure 17. The data show that, over the simulation period, the relative annual error (Qsim-Qobs)/Qobs where Qsim is the simulated streamflow and Qobs is the streamflow observed at the streamgage) is less than 5 percent. This result indicates the PRMS model simulates the overall water balance well and also indicates, over a sufficiently long period of time, the input precipitation totals and estimated evapotranspiration 
Table 5. Simulated and observed annual mean streamflow for the Pomperaug River at Southbury, Connecticut, for water years 1999 through 2005.

$\left[\mathrm{ft}^{3} / \mathrm{s}\right.$, cubic feet per second]

\begin{tabular}{ccccc}
\hline $\begin{array}{c}\text { Water } \\
\text { year }\end{array}$ & $\begin{array}{c}\text { Annual mean } \\
\text { daily flow } \\
\text { simulated } \\
\left.\mathbf{f t}^{3} / \mathbf{s}\right)\end{array}$ & $\begin{array}{c}\text { Annual mean } \\
\text { daily flow } \\
\text { observed } \\
\left.\mathbf{f t t}^{3} / \mathbf{s}\right)\end{array}$ & $\begin{array}{c}\text { Relative } \\
\text { error } \\
\text { (dimen- } \\
\text { sionless) }\end{array}$ & $\begin{array}{c}\text { Absolute } \\
\text { error } \\
\left(\mathbf{f t}^{3} / \mathbf{s}\right)\end{array}$ \\
\hline 1999 & 136.8 & 120.3 & 0.14 & 16.5 \\
2000 & 126.4 & 136.5 & -0.07 & -10.1 \\
2001 & 101.9 & 115.4 & -0.12 & -13.5 \\
2002 & 72.8 & 63.5 & 0.15 & 9.2 \\
2003 & 164.4 & 147.8 & 0.11 & 16.5 \\
2004 & 155.4 & 152.2 & 0.02 & 3.1 \\
2005 & 122.1 & 116.6 & 0.05 & 5.8 \\
Mean & $\mathbf{1 2 5 . 7}$ & $\mathbf{1 2 1 . 8}$ & $\mathbf{0 . 0 4}$ & $\mathbf{3 . 9}$ \\
\hline
\end{tabular}

Figure 17. Simulated and observed annual mean streamflow for the Pomperaug River at Southbury, Connecticut, for water years 1999 through 2005. for the watershed as a whole are reasonably well represented. However, for any given year, the total runoff may be in error by as much as 14 percent. This finding indicates the precipitation inputs are not fully representative of the watershed average for specific years. The absolute error Qsim-Qobs shows an average over-prediction of streamflow by $3.9 \mathrm{ft}^{3} / \mathrm{s}$.

The monthly mean simulated and observed streamflows at the Pomperaug River streamgage for 1998 to 2005 are shown on figure 18. The goodness of fit of the simulation, as indicated by a Nash-Sutcliffe model-efficiency coefficient (Nash and Sutcliffe, 1970) of 0.76, is relatively good and acceptable for PRMS model results (Hay and McCabe, 2002; Coon and Johnson, 2005). The coefficient of determination is 0.76 , which indicates about 76 percent of the variation in the observed record can be predicted from the simulated record.

The simulated mean monthly streamflow for the entire simulation period is $126 \mathrm{ft}^{3} / \mathrm{s}$, and the observed mean monthly streamflow for the same period is $122 \mathrm{ft}^{3} / \mathrm{s}$, a difference of less than 4 percent. The standard deviation of the simulated monthly flows is $81 \mathrm{ft}^{3} / \mathrm{s}$, whereas the standard deviation of the observed flows is $89 \mathrm{ft}^{3} / \mathrm{s}$. This finding indicates the simulated monthly means exhibit similar variability from month to month, with about 9 percent less variability in the simulated record. The mean of the monthly $\log$ residuals $\log (\mathrm{Q} \operatorname{sim})-$ $\log$ (Qobs) between the simulated and observed monthly streamflow is 0.04 , which indicates the mean error between

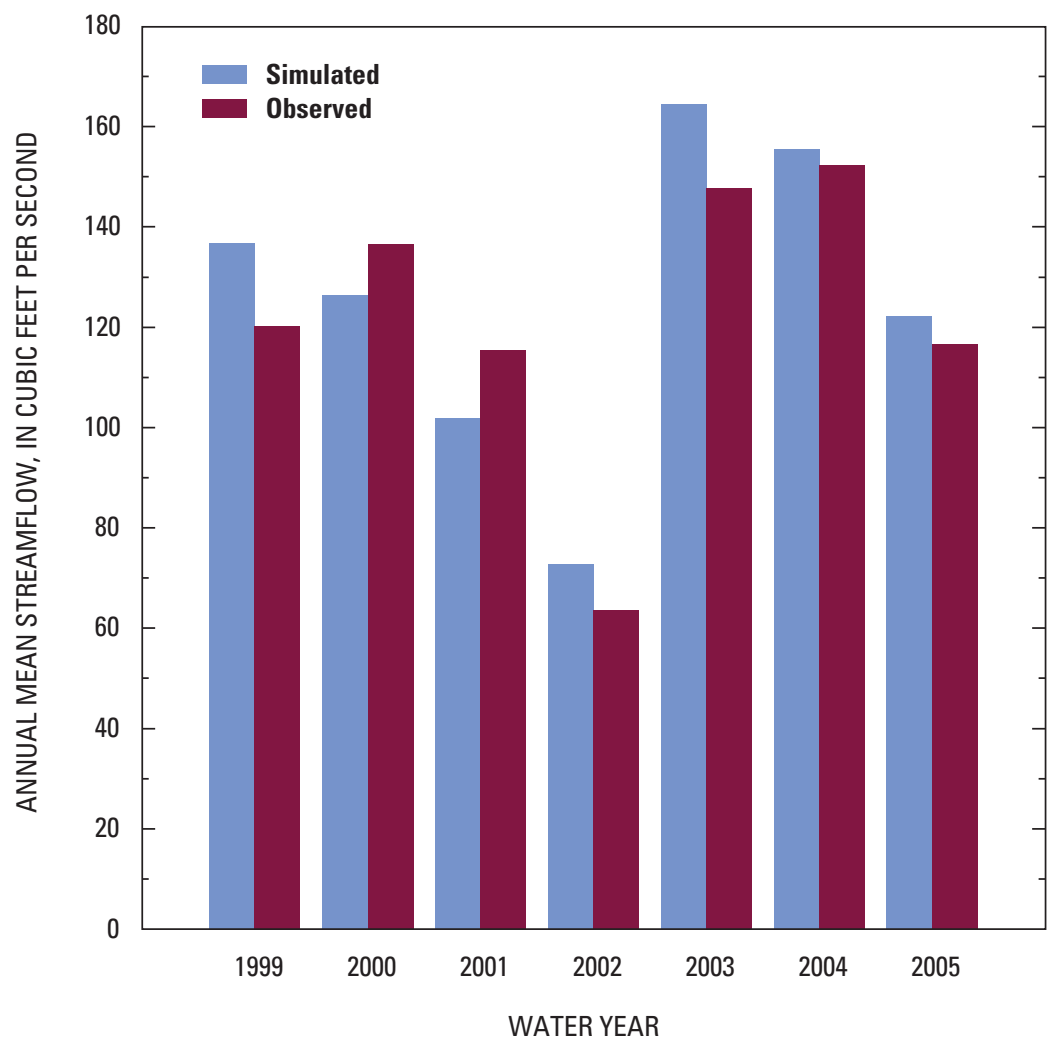




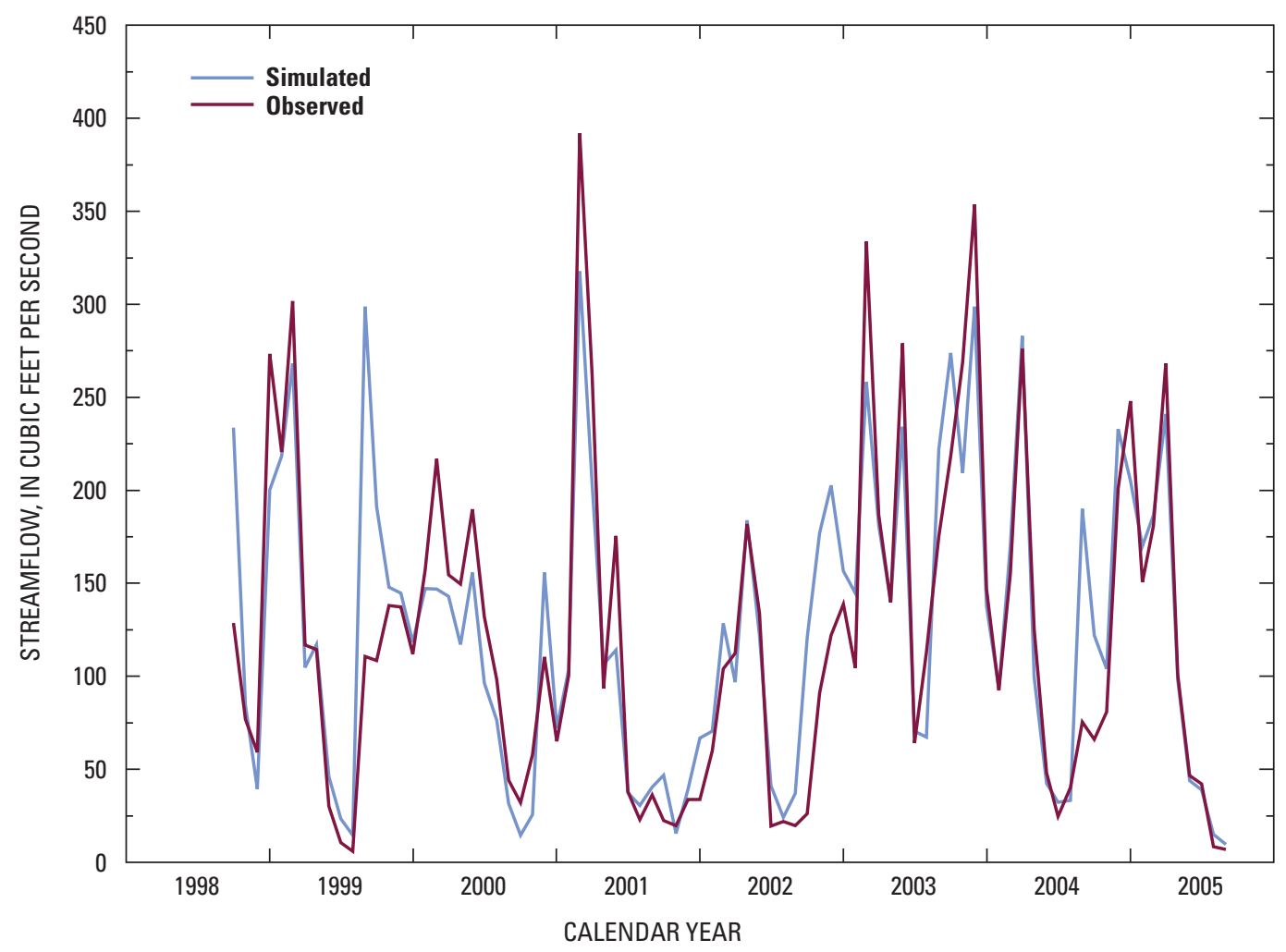

Figure 18. Simulated and observed monthly mean streamflows for the Pomperaug River at Southbury, Connecticut, for calendar years 1998 through 2005.

any given monthly mean estimate and the observed monthly mean is less than 10 percent. The log residual is used where the range of estimated streamflow values is greater than an order of magnitude. The standard deviation of the log residual for the monthly means is 0.17 (48 percent), which indicates there is greater error for any given monthly estimate compared to the long-term mean error.

The relative error for each month ranges from 1 to greater than 100 percent, and 20 percent of the months show errors greater than 50 percent. Eighty percent of the months with errors greater than 50 percent are during the late summer and fall (July through October). These months exhibit the highest variation in day-to-day and year-to-year precipitation between stations and at individual stations because of thunderstorms and large cyclonic systems (nor'easters and hurricanes) that can develop heavy and generally localized precipitation.

Within the daily precipitation record, there appear to be anomalies in total precipitation associated with most of the months with high errors. These anomalies consist of apparently excessive amounts of daily precipitation at one station, usually the Woodbury coop station. Although there is no means by which to say that these values are in error, particularly because they may reflect localized heavy rain, it is important to recognize that they might not be representative of the watershed and could certainly contribute to the monthly mean being too high. The precipitation input record shows that most months with a relative error greater than 50 percent contained a single anomalously high precipitation event at one of the stations and subsequent memory of this event in subsequent simulated daily streamflows.

The statistics of the daily simulated streamflows at the Pomperaug River at Southbury over the period of record 1999-2005 are provided on table 6 . The overall mean error between the observed and simulated daily streamflow record is shown on table 6 as the mean log residual, which is equivalent to an error of less than 4 percent, which is similar to the monthly means. However, there is greater variability in the simulated daily record than in the observed record, which is not the case for the monthly means. If adjustments to the simulated record to account for the effect of the O\&G ponds and groundwater diversions are not included, the simulated record shows much greater variability than the observed record and overall lower goodness-of-fit statistics. This finding indicates that groundwater diversions and particularly the off-channel flood storage in the O\&G ponds substantially affect the streamflow regime of the Pomperaug River at Southbury. 
Table 6. Daily and monthly streamflow statistics for the Pomperaug River at Southbury, Connecticut.

[na, not applicable]

\begin{tabular}{|c|c|c|c|c|c|}
\hline \multirow[b]{2}{*}{ Flow statistics } & \multicolumn{3}{|c|}{ Streamflow (cubic feet per second) } & \multirow[b]{2}{*}{$\begin{array}{l}\text { Log residual } \\
\text { without routing } \\
\text { and diversions }\end{array}$} & \multirow[b]{2}{*}{$\begin{array}{l}\text { Log residual } \\
\text { with routing and } \\
\text { diversions }\end{array}$} \\
\hline & Observed & $\begin{array}{l}\text { Simulated without } \\
\text { routing and } \\
\text { diversions }\end{array}$ & $\begin{array}{l}\text { Simulated with } \\
\text { routing and } \\
\text { diversions }\end{array}$ & & \\
\hline \multicolumn{6}{|c|}{ Recent data representing current land-use conditions, 1999-2005 } \\
\hline \multicolumn{6}{|c|}{ Daily } \\
\hline Mean & 122 & 128 & 126 & 0.032 & 0.019 \\
\hline Standard deviation & 148 & 184 & 159 & 0.239 & 0.239 \\
\hline Minimum & 3.6 & 7.3 & 4.9 & -1.066 & -1.082 \\
\hline Maximum & 1,670 & 2,737 & 1,677 & 1.115 & 1.034 \\
\hline Nash-Sutcliffe coefficient & na & 0.31 & 0.52 & na & na \\
\hline Coefficient of determination $\mathrm{R}^{2}$ & na & 0.55 & 0.61 & na & na \\
\hline \multicolumn{6}{|c|}{ Monthly } \\
\hline Mean & 122 & 128 & 126 & 0.054 & 0.040 \\
\hline Standard deviation & 89 & 82 & 81 & 0.177 & 0.173 \\
\hline Minimum & 5.9 & 12.2 & 9.1 & -0.324 & -0.354 \\
\hline Maximum & 391 & 333 & 318 & 0.671 & 0.664 \\
\hline Nash-Sutcliffe coefficient & na & 0.75 & 0.76 & na & na \\
\hline Coefficient of determination $\mathrm{R}^{2}$ & na & 0.75 & 0.76 & na & na \\
\hline \multicolumn{6}{|c|}{ Historical data, 1976-1999 } \\
\hline \multicolumn{6}{|c|}{ Daily } \\
\hline Mean & 139 & 139 & 138 & 0.010 & -0.005 \\
\hline Standard deviation & 216 & 204 & 194 & 0.221 & 0.228 \\
\hline Minimum & 3.3 & 3.6 & 2.6 & -1.353 & -1.423 \\
\hline Maximum & 5,500 & 4,382 & 3,678 & 0.933 & 0.931 \\
\hline Nash-Sutcliffe coefficient & na & 0.62 & 0.64 & na & na \\
\hline Coefficient of determination $\mathrm{R}^{2}$ & na & 0.64 & 0.65 & na & na \\
\hline \multicolumn{6}{|c|}{ Monthly } \\
\hline Mean & 139 & 139 & 138 & 0.019 & 0.009 \\
\hline Standard deviation & 118 & 105 & 106 & 0.163 & 0.165 \\
\hline Minimum & 5.8 & 8.4 & 6.4 & -0.581 & -0.639 \\
\hline Maximum & 671 & 525 & 524 & 0.463 & 0.452 \\
\hline Nash-Sutcliffe coefficient & na & 0.81 & 0.81 & na & na \\
\hline Coefficient of determination $\mathrm{R}^{2}$ & na & 0.81 & 0.81 & na & na \\
\hline
\end{tabular}


The simulated daily streamflow record for the historical period, 1976-1999, also shows good overall mean daily streamflow estimates (table 6); the mean log residual is less than 5 percent. However, the standard deviation of the simulated daily streamflow for this period of record was less than that for the observed record, suggesting that the attenuating effect of the O\&G ponds is not as important during this simulation period. This may be because of the gradual erosion of the streambank adjacent to the ponds such that the more recent record is subject to more frequent overbank flow into the pond system or the effect of using different data sets.

The simulated daily streamflows for the tributaries, the Weekeepeemee and Nonnewaug Rivers, for the recent data (2001-2005) also show good overall mean accuracy; mean log residual between the observed and simulated daily streamflows is less than 4 percent (table 7). Similar to the unadjusted Pomperaug River simulations, the standard deviations of the simulated streamflows are greater than for the observed records for both tributaries. The Nonnewaug simulated record included estimated out-of-watershed diversions from the Watertown Fire District and was adjusted by subtracting them directly from the time series of simulated streamflow. However, the unadjusted record more closely approximated the observed record at the Nonnewaug streamgage at low flow. This finding indicates the low-flow augmentation from the Bronson-Lockwood Reservoir is effective in compensating for the diversions.

The Weekeepeemee River has no documented diversions; however, there is a relatively large departure from the linear probability distribution for extreme low flows. This departure is not captured by the simulated record and may indicate an unknown low-flow diversion from the Weekeepeemee. Evidence of undocumented diversions from the river is based on anecdotal observations (Piotr Parasiewicz, Rushing Rivers Institute, written commun., 2007). Clearly, some of the discrepancies between the simulated and observed records for the Nonnewaug and Weekeepeemee streamgages may result from unknown effects of diversion, documented and undocumented, as well as unknown off-channel storage effects.

The simulated and observed daily streamflows for the Pomperaug, Weekeepeemee, and Nonnewaug Rivers are shown on figure 19. Some major flow events were not simulated by the model, and the model simulated major events that did not occur in the observed record. These results indicate the input data set does not fully represent the overall conditions in the watershed probably because of the localized nature of many events, as well as the xyz distribution assumptions inherent in the model (Hay and McCabe, 2002). The 1976-1999 data set for the Pomperaug River exhibits the same input-data issues indicating that even with a larger number of weather stations, accurately representing the precipitation and temperature distribution for the entire watershed is a problem.

The analysis of the residual statistics for the simulated and observed daily and monthly flow indicates the simulation predicts the long-term streamflow accurately, although there may be considerable error for any given day. The normal probability distribution and normal quartile distribution of the $\log$ residuals for all three streamgages for daily and monthly mean streamflow estimates are shown on figure 20. The plots indicate a tendency to show non-normal error response at the high and low extremes of the hydrograph for the daily residuals (figs. 20A and 20B) and at the high end for the monthly residuals (figs. 20C and 20D). This tendency is evident at all three streamgages. The majority of the estimated streamflow values at all the streamgages were normally distributed, however, showing random error.

The random error over most of the streamflow range indicates the model errors primarily result from error in the input-data distribution, rather than a model bias that would result if a major hydrogeologic process was not represented in the model. Also, the model does not show any trend in time, indicating the simulated water balance and storage fluxes generally are unbiased and representative of the long-term hydrologic processes in the watershed. The greater non-random error at the high end of the distribution suggests either a bias in the input data, with a tendency towards nonrepresentative precipitation over the watershed for the largest events, or indicates the model over-predicts runoff at the high end, possibly because of over-representation of the size of the maximum contributing area during large runoff events (smidx module). Another issue is the potential for error in the observed streamflow values themselves, which is unknown at the extreme ends of the hydrograph, and issues of unknown withdrawals from streams and inaccurate representation of overbank storage (such as in the O\&G ponds). Taken together, the residual distribution patterns indicate the model estimates of the highest flows should be used with caution and may not be entirely representative of runoff processes that generate these large events. However, the majority of streamflow estimates, including the monthly mean estimates of the lowest flows, are unbiased and representative of the groundwater and surface-water processes in the watershed.

The exact timing of peak flows is of secondary importance compared with preserving the range of flows over the simulation record. This is because, from the habitat and land/water-use management perspective of the study, it is more important to simulate the statistical characteristics of the flow record than to predict a specific event. Thus, flowduration curves provide the most appropriate comparative result. The simulated and observed flow-duration curves for the Pomperaug, Nonnewaug, and Weekeepeemee Rivers using the recent data set (1999-2005) are shown on figure 21. The patterns are similar to those observed on the residual plots. Streamflow statistics for specific flow percentiles are shown on table 8. Comparison between the observed and simulated flows for the Pomperaug, Weekeepeemee, and unadjusted Nonnewaug Rivers shows that most estimates of the specific flow frequencies are within 10 percent, and that the extreme high and low percentiles are within 30 percent. This result indicates relatively good simulation (Coon and Johnson, 2005). 
Table 7. Daily and monthly streamflow statistics for the Weekeepeemee and Nonnewaug Rivers, Connecticut.

[na, not applicable]

\begin{tabular}{|c|c|c|c|c|c|}
\hline \multirow[b]{2}{*}{ Flow statistics } & \multicolumn{3}{|c|}{ Streamflow (cubic feet per second) } & \multirow[b]{2}{*}{$\begin{array}{l}\text { Log residual } \\
\text { without routing } \\
\text { and diversions }\end{array}$} & \multirow[b]{2}{*}{$\begin{array}{l}\text { Log residual } \\
\text { with routing and } \\
\text { diversions }\end{array}$} \\
\hline & Observed & $\begin{array}{l}\text { Simulated without } \\
\text { routing and } \\
\text { diversions }\end{array}$ & $\begin{array}{l}\text { Simulated with } \\
\text { routing and } \\
\text { diversions }\end{array}$ & & \\
\hline \multicolumn{6}{|c|}{ Recent data representing current land-use conditions, 2000-2005 } \\
\hline \multicolumn{6}{|c|}{ Weekeepeemee River } \\
\hline \multicolumn{6}{|c|}{ Daily } \\
\hline Mean & 47 & 45 & na & 0.003 & na \\
\hline Standard deviation & 60 & 75 & na & 0.292 & na \\
\hline Minimum & 0.1 & 1.7 & na & -1.133 & na \\
\hline Maximum & 680 & 984 & na & 1.614 & na \\
\hline Nash-Sutcliffe coefficient & na & 0.38 & na & na & na \\
\hline Coefficient of determination $\mathrm{R}^{2}$ & na & 0.60 & na & na & na \\
\hline \multicolumn{6}{|c|}{ Monthly } \\
\hline Mean & 47 & 45 & na & 0.018 & na \\
\hline Standard deviation & 37 & 34 & na & 0.222 & na \\
\hline Minimum & 0.9 & 2.9 & na & -0.497 & na \\
\hline Maximum & 141 & 136 & na & 0.660 & na \\
\hline Nash-Sutcliffe coefficient & na & 0.80 & na & na & na \\
\hline Coefficient of determination $\mathrm{R}^{2}$ & na & 0.80 & na & na & na \\
\hline \multicolumn{6}{|c|}{ Nonnewaug River } \\
\hline \multicolumn{6}{|c|}{ Daily } \\
\hline Mean & 31 & 30 & 30 & 0.003 & -0.098 \\
\hline Standard deviation & 42 & 44 & 44 & 0.293 & 0.462 \\
\hline Minimum & 0.5 & 0.28 & 0.01 & -1.054 & -2.771 \\
\hline Maximum & 442 & 613 & 613 & 0.973 & 0.970 \\
\hline Nash-Sutcliffe coefficient & na & 0.58 & 0.58 & na & na \\
\hline Coefficient of determination $\mathrm{R}^{2}$ & na & 0.64 & 0.64 & na & na \\
\hline \multicolumn{6}{|c|}{ Monthly } \\
\hline Mean & 31 & 30 & 30 & 0.008 & -0.030 \\
\hline Standard deviation & 25 & 23 & 23 & 0.209 & 0.230 \\
\hline Minimum & 1.4 & 1.1 & 0.4 & -0.362 & -0.552 \\
\hline Maximum & 101 & 89 & 89 & 0.751 & 0.743 \\
\hline Nash-Sutcliffe coefficient & na & 0.78 & 0.77 & na & na \\
\hline Coefficient of determination $\mathrm{R}^{2}$ & na & 0.78 & 0.78 & na & na \\
\hline
\end{tabular}




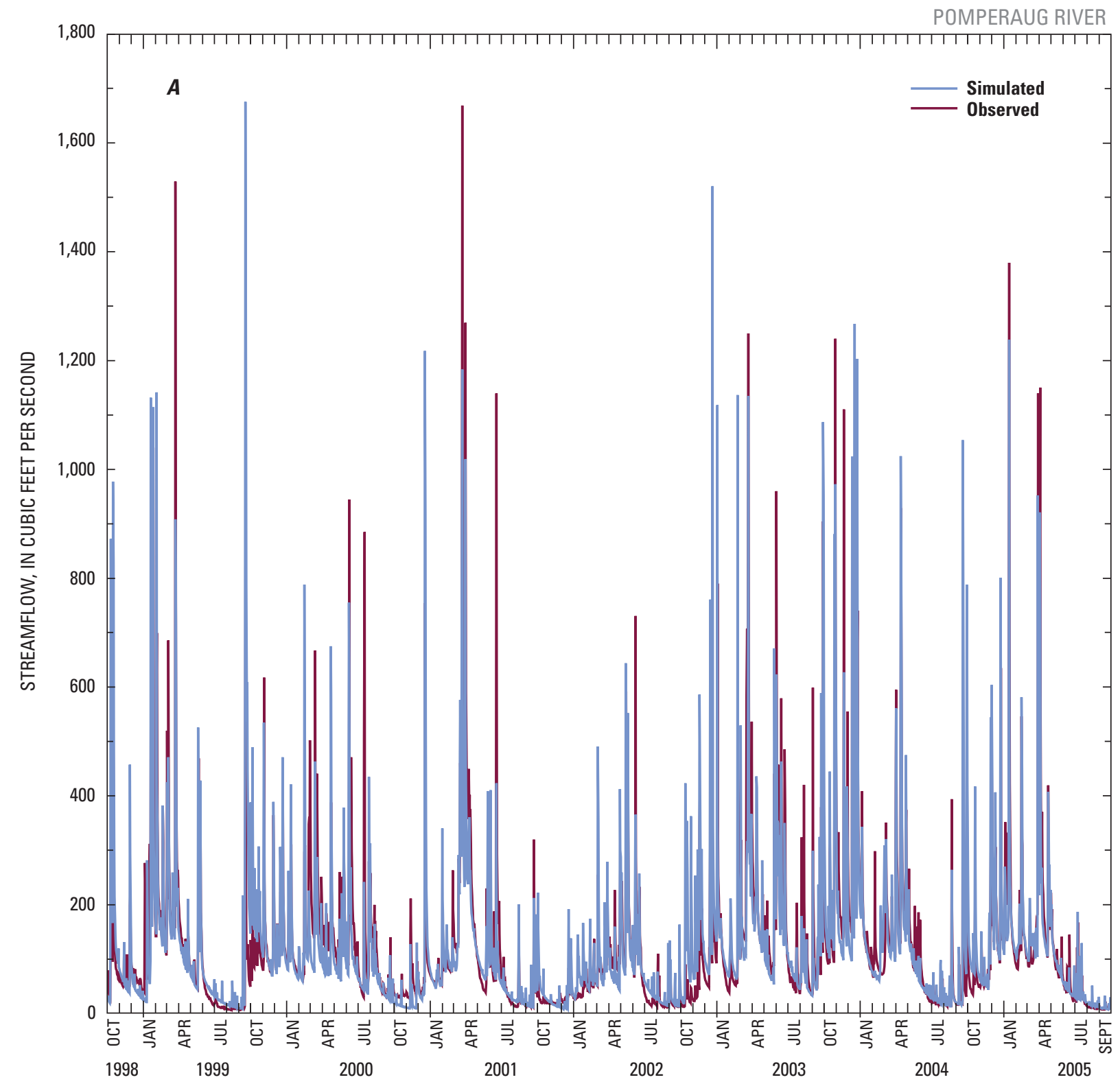

Figure 19. Simulated and observed daily streamflow for the (A) Pomperaug $(B)$ Nonnewaug and $(C)$ Weekeepeemee Rivers, Connecticut. 


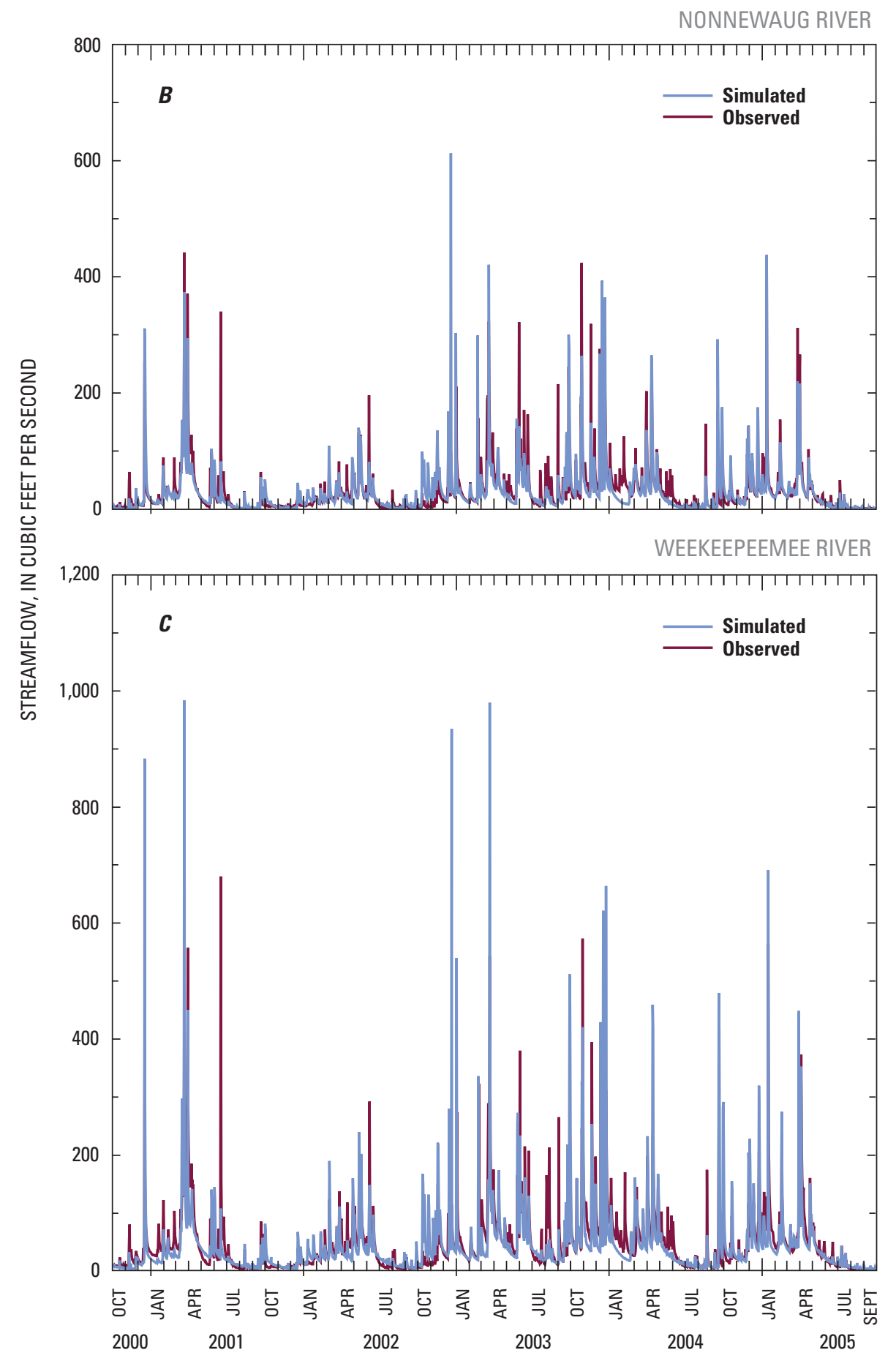

Figure 19. Simulated and observed daily streamflow for the $(A)$ Pomperaug $(B)$ Nonnewaug and (C) Weekeepeemee Rivers, Connecticut.-Continued 

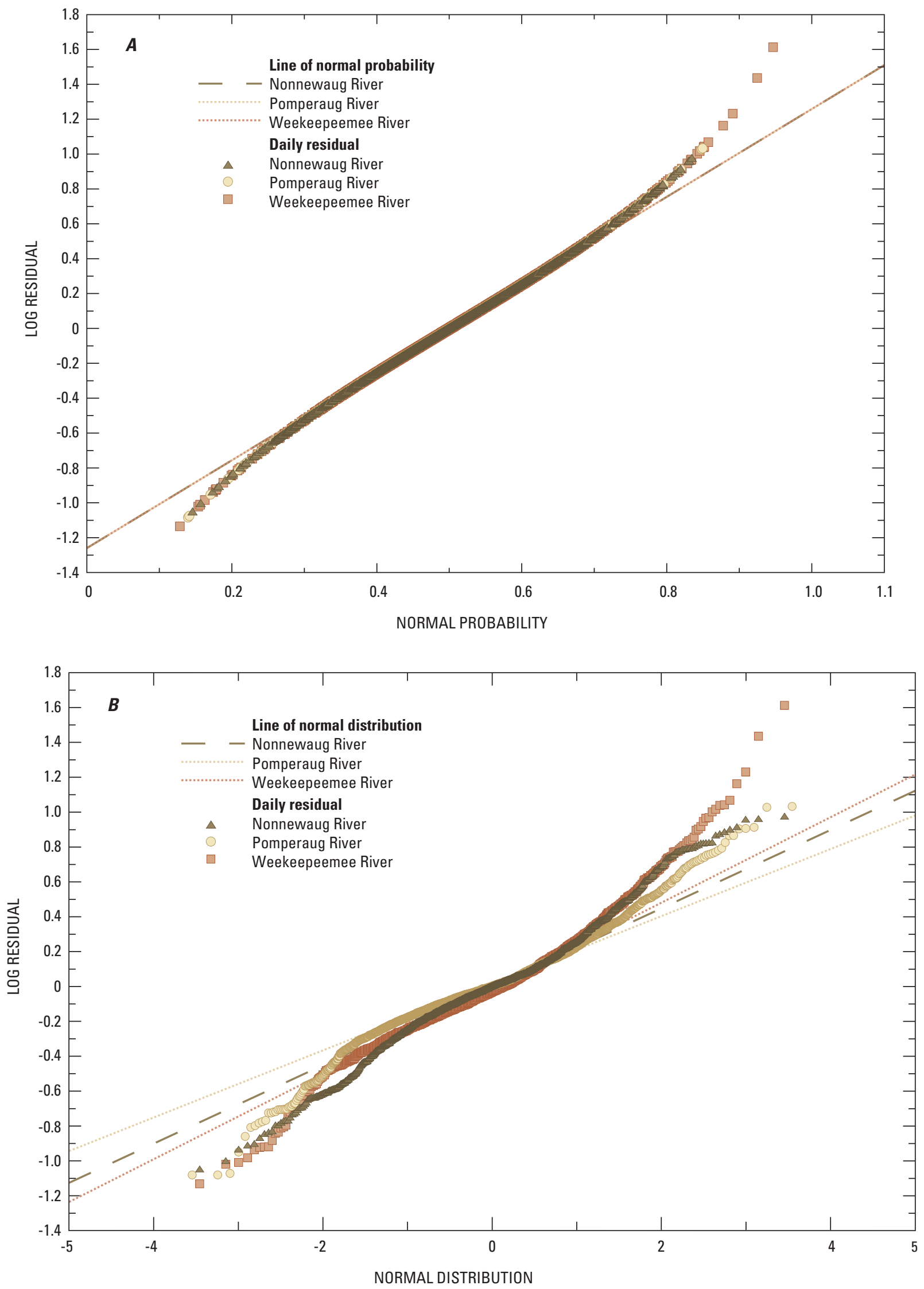

Figure 20. Log residual probability and quartile distribution plots, showing the fit line if the residuals are normally distributed, for the daily residuals $(A$ and $B$ ) and the monthly residuals $(C$ and $D)$, Pomperaug, Weekeepeemee, and Nonnewaug Rivers, Connecticut. 

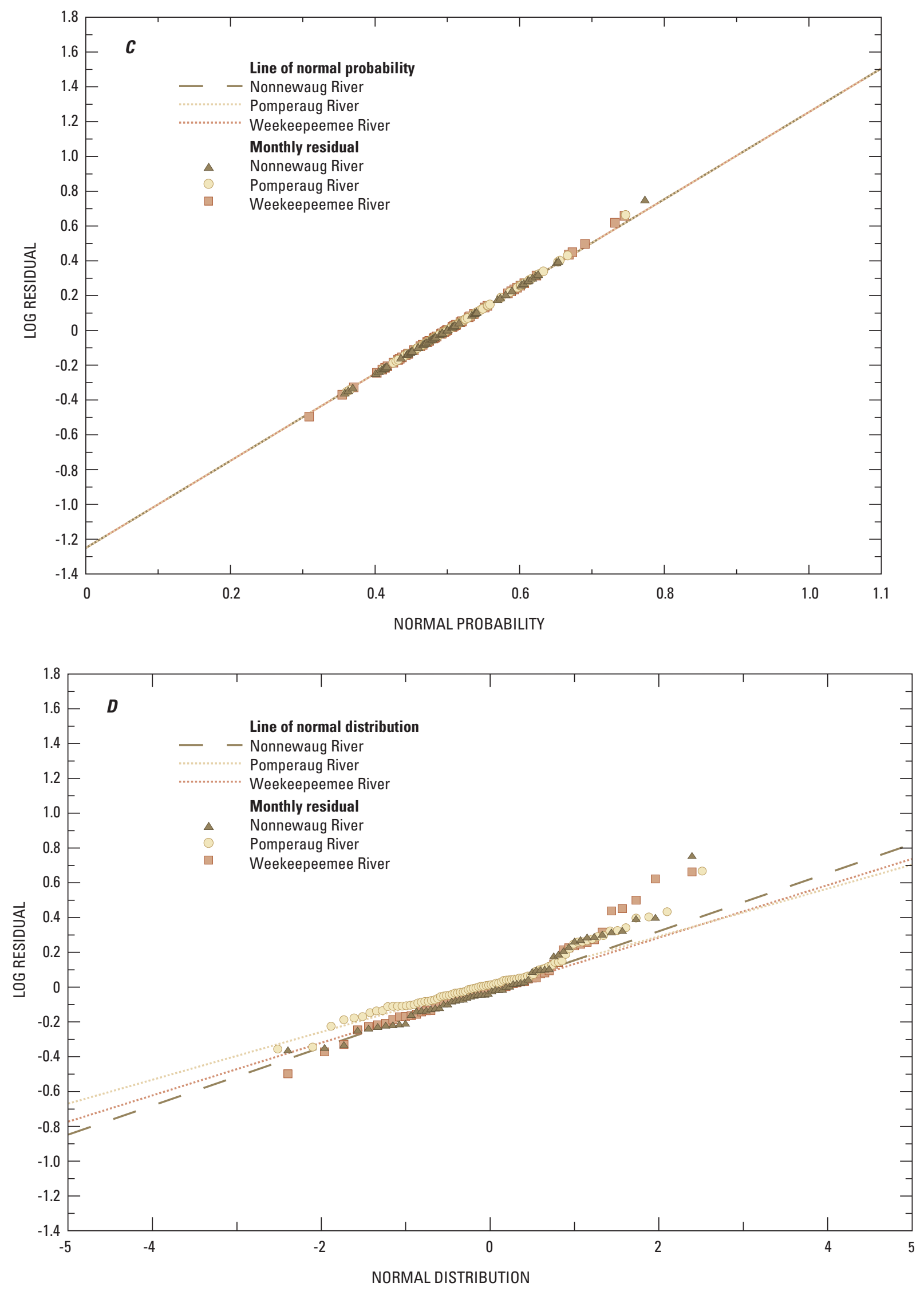

Figure 20. Log residual probability and quartile distribution plots, showing the fit line if the residuals are normally distributed, for the daily residuals $(A$ and $B$ ) and the monthly residuals $(C$ and $D$ ), Pomperaug, Weekeepeemee, and Nonnewaug Rivers, Connecticut.—Continued 

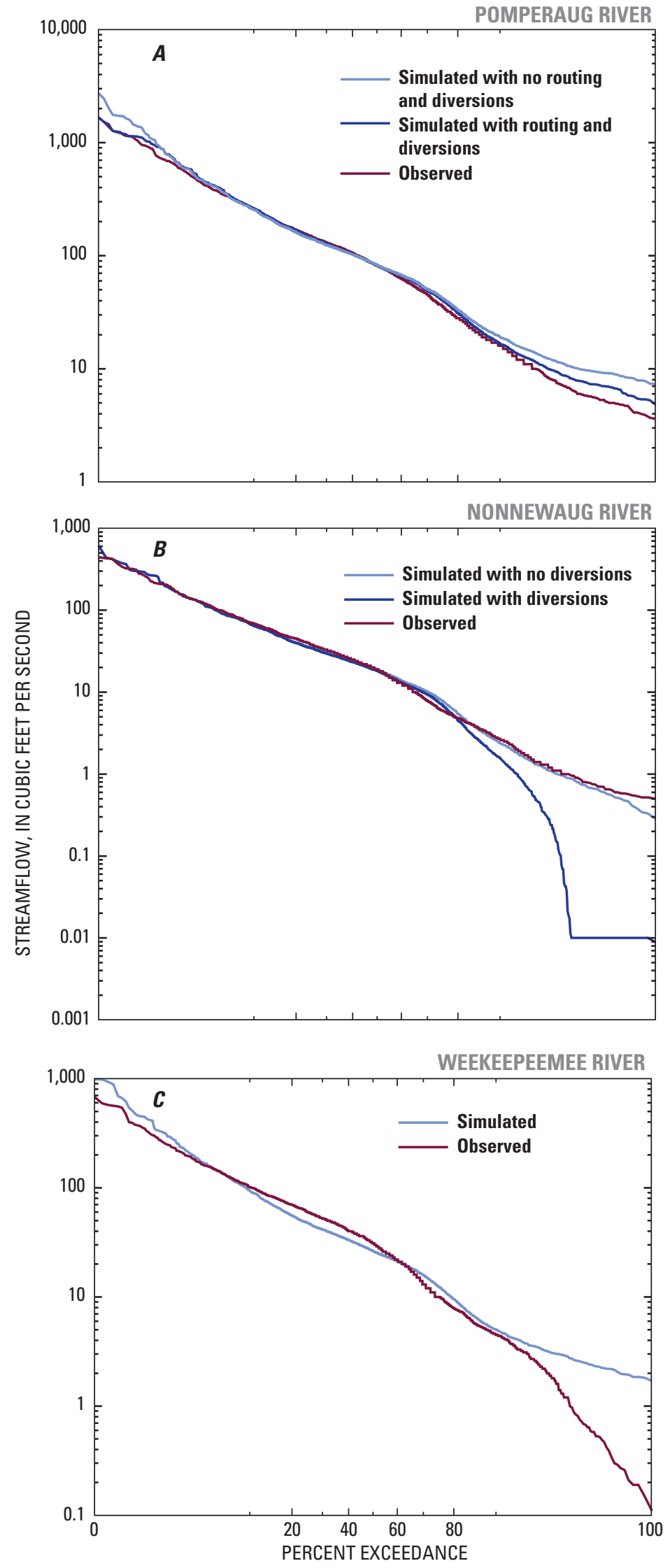

Figure 21. Simulated and observed flow-duration curves for the (A) Pomperaug (B) Nonnewaug and (C) Weekeepeemee Rivers, Connecticut. 
Table 8. Simulated and observed streamflow percentiles for the Pomperaug, Weekeepeemee, and Nonnewaug Rivers, Connecticut, October 1, 1998, to September 30, 2005.

$[\%$, percent $]$

\begin{tabular}{|c|c|c|c|}
\hline \multirow[b]{2}{*}{ Flow percentile } & \multicolumn{3}{|c|}{ Flow value (cubic feet per second) } \\
\hline & Observed & $\begin{array}{l}\text { Simulated without } \\
\text { routing and diversions }\end{array}$ & $\begin{array}{l}\text { Simulated with } \\
\text { routing and diversions }\end{array}$ \\
\hline \multicolumn{4}{|c|}{ Pomperaug River } \\
\hline 0.01 - Exceeded $99 \%$ of the time & 5.6 & 9.4 & 7.3 \\
\hline 0.10 - Exceeded $90 \%$ of the time & 16 & 19 & 17 \\
\hline 0.25 - Exceeded $75 \%$ of the time & 36 & 43 & 41 \\
\hline 0.50 - Exceeded $50 \%$ of the time & 82 & 83 & 82 \\
\hline 0.75 - Exceeded $25 \%$ of the time & 147 & 141 & 144 \\
\hline 0.90 - Exceeded $10 \%$ of the time & 257 & 256 & 262 \\
\hline 0.99 - Exceeded $1 \%$ of the time & 746 & 945 & 917 \\
\hline \multicolumn{4}{|c|}{ Weekeepeemee River } \\
\hline 0.01 - Exceeded $99 \%$ of the time & 0.6 & 2.4 & 2.4 \\
\hline 0.10 - Exceeded $90 \%$ of the time & 4.5 & 5.0 & 5.0 \\
\hline 0.25 - Exceeded $75 \%$ of the time & 10 & 12 & 12 \\
\hline 0.50 - Exceeded $50 \%$ of the time & 31 & 26 & 26 \\
\hline 0.75 - Exceeded $25 \%$ of the time & 60 & 47 & 47 \\
\hline 0.90 - Exceeded $10 \%$ of the time & 102 & 94 & 94 \\
\hline 0.99 - Exceeded $1 \%$ of the time & 299 & 349 & 349 \\
\hline \multicolumn{4}{|c|}{ Nonnewaug River } \\
\hline 0.01 - Exceeded $99 \%$ of the time & 0.7 & 0.7 & 0.01 \\
\hline 0.10 - Exceeded $90 \%$ of the time & 2.7 & 2.4 & 1.6 \\
\hline 0.25 - Exceeded $75 \%$ of the time & 6 & 7.9 & 7.1 \\
\hline 0.50 - Exceeded $50 \%$ of the time & 19 & 19 & 18 \\
\hline 0.75 - Exceeded $25 \%$ of the time & 38 & 35 & 34 \\
\hline 0.90 - Exceeded $10 \%$ of the time & 69 & 65 & 64 \\
\hline 0.99 - Exceeded $1 \%$ of the time & 211 & 245 & 245 \\
\hline
\end{tabular}

Deviations from the observed low flows for the Pomperaug River indicate that groundwater withdrawals and diversions may not be fully accounted for in the streamflowadjustment strategy. On the basis of pumping records from the three major groundwater systems in the watershed, out-ofwatershed groundwater diversions may account for 2 to $3 \mathrm{ft}^{3} / \mathrm{s}$ (which is less than 3 percent of the observed mean annual daily flow for the period 1998 through 2005, and nearly 100 percent of the lowest observed flows for the Pomperaug River at Southbury for the same time period). Additionally, if a base-flow reduction function that accounts for the flattening of the hydraulic gradient by a drop in water level (with a subsequent reduction in flow rate) during low-flow periods is assumed, the low-flow deviation observed on the simulated flow-duration curve can be adjusted to match the observed flow duration. These groundwater complexities cannot be fully accounted for within the groundwater module of the PRMS model.
The flow-duration curves and table 8 show that the PRMS model provides good representation of the overall flow statistics of the Pomperaug River considering flow diversions and high-flow routing through the abandoned quarry ponds. The simulated extreme low flows for the Nonnewaug River, in accounting for diversions from the Watertown Fire District wells, indicate the river runs nearly dry at times, which is not observed at the streamgage. This finding apparently is because of management practices implemented by the Watertown Fire District, which augments low flows by releasing stored water from the Bronson-Lockwood Reservoir upstream, thus maintaining flow levels in the river and filling a series of infiltration ponds at the well field. This management practice, if assumed to be sufficient to compensate for flow reductions caused by pumping and out-of-watershed diversions at the well field, would indicate the simulated flow-duration curve, assuming no diversions, is more representative of the observed flow conditions. 
As previously discussed, the simulated flow-duration curve for the Weekeepeemee River shows deviations from the observed record at the high and low end. There may be undocumented diversions from the river, which could cause lower observed flows that would account for some of the observed discrepancies with the simulated record. Despite these issues, the Nonnewaug simulation and to a large extent the Weekeepeemee simulation provide good representation of the natural flow statistics for the tributaries. Thus, changes to the streamflow regime as a result of physical changes in the watershed (changes to land use and land cover, for example) are expected to be appropriately quantified and distributed within the watershed over most of the natural range of flows.

Further analysis of the simulated and observed streamflows for the tributaries was accomplished by evaluating the dynamics of the ratio of the flows in the tributaries (Nonnewaug and Weekeepeemee Rivers) to the Pomperaug River flow. The statistical characteristics of the observed and simulated flow ratios for the two tributary streams are presented on table 9. Most of the simulated streamflow ratios reproduce the mean, maximum, minimum, and standard deviation of the range of values that occur in the observations. This finding indicates that on average, the simulated streamflows are properly quantified and distributed across the watershed.

Exceptions to the general agreement between observed and simulated streamflow statistics are the standard deviation and maximum of the ratio of the Nonnewaug to Weekeepeemee River. The observed record shows much lower flow in the Weekeepeemee River in the summer of 2005 than was observed during the previous 5 years or than was simulated by the model. During this period, the amount of precipitation during the summer was not particularly low relative to previous years, indicating the extreme low flows in the Weekeepeemee River may be caused by undocumented diversions, but may also be due in part to errors of low-flow extrapolation of the rating curve for the streamgage. This latter possibility, however, is not considered to be responsible for a large percentage of the apparent change in the flow relation. Another exception is the minimum of the ratio of the Weekeepeemee to Pomperaug streamflow. The observed record shows much lower extreme values for this ratio relative to the simulated record, further indicating the possibility of undocumented diversions in the Weekeepeemee River and (or) an indication that the model simulation over-represents storage in the Weekeepeemee tributary watershed.

\section{Flow Components and Groundwater Recharge}

The component breakdown of the hydrograph simulated by PRMS provides an opportunity to evaluate the model representation of the runoff and flow processes. It was assumed that the surface-runoff component of the hydrograph was essentially fixed by the assumptions regarding runoff response to impervious area and variable-source contributing areas. The model parameters that control surface runoff were developed from observed information; however, the surface-runoff volume cannot be independently evaluated or verified. The subsurface-reservoir parameterization was based on physical characteristics of the watershed, although the physical characteristics were optimized for the watershed. Because of this, the simulated volume of subsurface runoff cannot be independently evaluated or verified. In contrast, the simulated groundwater-runoff component of the hydrograph can be evaluated and verified on the basis of independent estimates.

Table 9. Tributary flow-ratio statistics for the Pomperaug, Weekeepeemee, and Nonnewaug Rivers, Connecticut.

[USGS, U.S. Geological Survey; Pomperaug River at USGS streamgage 01204000, Weekeepeemee River at USGS streamgage 012203805, and Nonnewaug River at USGS streamgage 01203600]

\begin{tabular}{|c|c|c|c|c|}
\hline $\begin{array}{l}\text { Tributary flow-ratio } \\
\text { statistics 2001-2005 }\end{array}$ & $\begin{array}{c}\text { Ratio of Nonnewaug to } \\
\text { Pomperaug daily } \\
\text { flow-observed }\end{array}$ & $\begin{array}{l}\text { Ratio of Nonnewaug to } \\
\text { Pomperaug daily } \\
\text { flow-simulated }\end{array}$ & $\begin{array}{c}\text { Ratio of Weekeepeemee } \\
\text { to Pomperaug daily } \\
\text { flow-observed }\end{array}$ & $\begin{array}{c}\text { Ratio of Weekeepeemee } \\
\text { to Pomperaug daily } \\
\text { flow-simulated }\end{array}$ \\
\hline Mean & 0.23 & 0.21 & 0.37 & 0.34 \\
\hline Standard deviation & 0.08 & 0.07 & 0.10 & 0.06 \\
\hline Minimum & 0.04 & Less than 0.01 & 0.02 & 0.14 \\
\hline Maximum & 0.81 & 0.61 & 1.28 & 0.86 \\
\hline $\begin{array}{l}\text { Tributary flow-ratio } \\
\text { statistics 2000-2005 }\end{array}$ & $\begin{array}{c}\text { Ratio of Nonnewaug to } \\
\text { Weekeepeemee daily } \\
\text { flow-observed }\end{array}$ & $\begin{array}{l}\text { Ratio of Nonnewaug to } \\
\text { Weekeepeemee daily } \\
\text { flow-simulated }\end{array}$ & & \\
\hline Mean & 0.68 & 0.62 & & \\
\hline Standard deviation & 0.38 & 0.25 & & \\
\hline Minimum & 0.14 & Less than 0.01 & & \\
\hline Maximum & 6.45 & 2.77 & & \\
\hline
\end{tabular}


The groundwater-runoff (base-flow) component of the simulated streamflow over the long term is equal to recharge of the groundwater reservoir. Thus, estimates of groundwater recharge serve as a point of verification for the groundwater runoff as well as recharge estimates simulated by the model. Additionally, estimates of groundwater runoff to the Pomperaug River derived from hydrograph-separation techniques can provide a point of verification for the simulated groundwater runoff.

The simulated hydrograph-component runoff quantities, as a percentage of the total flow, for the Pomperaug, Weekeepeemee, and Nonnewaug Rivers are shown on table 10. On the basis of manual hydrograph-separation techniques, groundwater flow has been estimated as approximately 45 percent of the total flow (Meinzer and Stearns, 1929). Similarly, a recharge estimation equation developed by Mazzaferro (1986b) for Connecticut predicts that groundwater flow/recharge would be approximately 43 percent of total flow. However, during the Meinzer and Stearns study (1929), the majority of the watershed was under agriculture that used large water withdrawals from local surface-water bodies for irrigation (J.L. Pond, Pomperaug River Watershed Coalition, oral commun., 2005). Although the effects of these withdrawals are unknown (and cannot be quantified), it is likely that they reduced low flows and would be reflected in decreased base flows.

More recently, automated hydrograph-separation techniques have been developed to estimate the groundwaterrunoff component of streamflow (Rutledge, 1998). These methods estimate that groundwater runoff accounts for approximately 70 percent of the total flow for the Pomperaug River. The hydrograph-separation techniques do not distinguish between groundwater and subsurface runoff and inherently include some of the subsurface runoff in the baseflow estimates. If it is assumed that half of the subsurfacerunoff component is included in the base-flow estimates, the actual groundwater runoff would be more on the order of 70 percent, comparable to estimates derived using base-flow separation techniques (Rutledge, 1998).

The manual hydrograph-separation techniques employed by Meinzer and Stearns (1929) and Mazzaferro (1986b) involve a certain degree of subjectivity and may underestimate the more rapid groundwater response that occurs after large recharge events. Therefore, these estimates may not be as reliable as the method developed by Rutledge, 1993; Rutledge, 1998, which identifies logarithmic decay functions consistent with the mechanics of groundwater flow. However, the Rutledge methods may include elements of runoff generated from shallow groundwater reservoirs that are included as part of the subsurface-runoff component in the PRMS model, or even surface-water storage reservoirs that exhibit logarithmic declines in flow rates. On balance, it is expected that the "true" groundwater-runoff component would be somewhere between 45 and 70 percent of the total flow. The PRMS groundwaterrunoff estimate for the Pomperaug River is approximately 60 percent of the total flow, which is in the expected range. The groundwater contribution from each HRU varies in large part as a function of the percentage of coarse glacial stratified deposits, and there is a strong linear relation between the percentage of groundwater contribution and the percentage of

Table 10. Simulated flow component contribution to the Pomperaug, Weekeepeemee, and Nonnewaug Rivers, Connecticut, at their respective gages.

\begin{tabular}{|c|c|c|c|}
\hline Statistic & Groundwater runoff & Surface runoff & Subsurface runoff \\
\hline \multicolumn{4}{|c|}{$\begin{array}{l}\text { Pomperaug River source-water contribution 1976-1998 } \\
\text { (12.7 percent coarse glacial stratified deposits) }\end{array}$} \\
\hline Mean daily runoff (cubic feet per second) & 81.3 & 20.3 & 38.6 \\
\hline Fraction of total & 58 & 15 & 27 \\
\hline \multicolumn{4}{|c|}{$\begin{array}{c}\text { Pomperaug River source-water contribution 1999-2005 } \\
\text { (12.7 percent coarse glacial stratified deposits) }\end{array}$} \\
\hline Mean daily runoff (cubic feet per second) & 72.6 & 20.5 & 34.8 \\
\hline Fraction of total & 57 & 16 & 27 \\
\hline \multicolumn{4}{|c|}{$\begin{array}{l}\text { Weekeepeemee River source-water contribution 1999-2005 } \\
\text { (7.0 percent coarse glacial stratified deposits) }\end{array}$} \\
\hline Mean daily runoff (cubic feet per second) & 24.3 & 6.2 & 15.9 \\
\hline Fraction of total & 53 & 13 & 34 \\
\hline \multicolumn{4}{|c|}{$\begin{array}{l}\text { Nonnewaug River source-water contribution 1999-2005 } \\
\text { (9.4 percent coarse glacial stratified deposits) }\end{array}$} \\
\hline Mean daily runoff (cubic feet per second) & 17.0 & 3.4 & 10.5 \\
\hline Fraction of total & 55 & 11 & 34 \\
\hline
\end{tabular}


coarse glacial stratified deposits in each watershed similar to the findings of Mazzaferro (1986b).

The PART base-flow separation program (Rutledge, 1993; Rutledge, 1998) was used to characterize and compare the daily observed and simulated base-flow contribution to the Pomperaug River at the Southbury streamgage. The estimated base-flow contribution also is used to compare the observed and simulated estimates of long-term groundwater recharge assuming that the long-term base flow is equivalent to the long-term recharge. As discussed previously in the description of the watershed, the estimates of groundwater base flow and recharge determined by PART are typically high relative to other estimation methods and include a portion of rapid subsurface runoff. Considering this, the PART program is used to provide a consistent estimation methodology for daily measurements as a means to compare the observed and simulated records. The comparative annual mean base-flow statistics derived from PART are provided on table 11. A comparison of information on tables 5 and 11 indicates that PRMS simulates base flow better than total streamflow. The model simulation provides good estimates of both the short-term and long-term recharge and base flow.

Another approach to assessing how well PRMS simulates the base flow is to compare the slope of the log-log plot of the observed and simulated base-flow recession time-series data for a number of time periods. This slope is independent of the absolute magnitude of the flow values and is a characteristic of the base-flow decay. The statistic provides a direct comparison of how well PRMS simulates the base-flow decay process whether or not the individual recession being compared has

Table 11. Simulated and observed annual mean base flow estimated using PART.

$\left[\mathrm{ft}^{3} / \mathrm{s}\right.$, cubic feet per second]

\begin{tabular}{ccccc}
\hline $\begin{array}{c}\text { Water } \\
\text { year }\end{array}$ & $\begin{array}{c}\text { Annual } \\
\text { mean flow } \\
\text { observed } \\
\left(\mathbf{f t}^{3} / \mathbf{s}\right)\end{array}$ & $\begin{array}{c}\text { Annual } \\
\text { mean flow } \\
\text { simulated } \\
\left(\mathbf{f t}^{3} / \mathbf{s}\right)\end{array}$ & $\begin{array}{c}\text { Relative } \\
\text { error } \\
\text { (dimen- } \\
\text { sionless) }\end{array}$ & $\begin{array}{c}\text { Absolute } \\
\text { error } \\
\left(\mathbf{f t}^{3} / \mathbf{s}\right)\end{array}$ \\
\hline 1999 & 69.5 & 75.1 & 0.08 & 5.6 \\
2000 & 94.4 & 80.9 & -0.14 & -13.5 \\
2001 & 76.7 & 64.4 & -0.16 & -12.3 \\
2002 & 43.3 & 44.1 & 0.02 & 0.8 \\
2003 & 91.3 & 95.9 & 0.05 & 4.6 \\
2004 & 100.2 & 92.0 & -0.08 & -8.2 \\
2005 & 78.0 & 79.7 & 0.02 & 1.7 \\
Mean & $\mathbf{7 9 . 1}$ & $\mathbf{7 6 . 0}$ & $\mathbf{- 0 . 0 3}$ & $\mathbf{- 3 . 0}$ \\
\hline
\end{tabular}

the correct magnitude. Thirty-nine recession periods were analyzed, ranging from 6 to 24 days in length, during which the daily flow consisted entirely of base flow (as determined by PART). The recession periods selected spanned all seasons of the year. The comparative statistics of this analysis are shown on table 12 and indicate that PRMS generally duplicated the measured recessions relatively accurately. This result supports the previous indication that the PRMS recharge and base-flow simulation can be reasonably expected to duplicate watershed base flow and recharge processes with an accuracy sufficient for understanding how land-use change would affect recharge and base flow.

The estimated mean annual recharge to till and coarse glacial stratified aquifers in the Pomperaug River watershed is shown on table 13. This information is based on the general relation derived from PRMS that indicates 77 percent of the variance associated with recharge is due to the percentage of coarse glacial deposits in an HRU (red line on fig. 22). The PRMS-estimated recharge is similar to the previous estimates of recharge by Starn and others (2000) and Mazzaferro (1986b). These comparisons indicate the recharge and groundwater-discharge estimates derived from the PRMS simulation are reasonably represented and can be considered to meet the objectives of the modeling.

The simulated recharge variability indicates that the larger the percentage of coarse glacial stratified deposits in an HRU, the more variable the recharge. Large recharge events, which likely cause the variability, are more likely to occur in HRUs dominated by coarse glacial stratified deposits. Also, there are higher percentages of class D soils in upland areas. During periods of low flow when there is no surface runoff and little or no subsurface runoff, the streamflow is maintained by groundwater runoff. During these periods, the percent coarse glacial stratified deposits in the HRU indicates the contribution that the HRU has in maintaining flow in the river.

The change in percent contribution of the three runoff components for South Brook, a small tributary to the Pomperaug, is shown on table 14. The HRUs that comprise the South Brook watershed include an upland HRU with 1 percent coarse glacial stratified deposits, a transitional HRU with 4 percent coarse glacial stratified deposits, and a valley bottom HRU with 100 percent coarse glacial stratified deposits. The change in runoff-component quantity for South Brook illustrates the effect that watershed position and percent coarse glacial stratified deposits in the HRU had on the simulated flow, with a dramatic shift in the dominant flow-generating mechanisms depending on these factors.

The spatially distributed recharge by month for each HRU, over the period of simulated record, is shown on figure 23. Recharge is typically greatest in March. Additionally, the greatest amount of recharge occurs in the valley bottoms (fig. 23), although in some cases, upland HRUs can show relatively large recharge. Similarly, the spatial distribution of mean subsurface runoff and surface runoff are shown on figures 24 and 25 , respectively. 
Table 12. Daily and monthly base-flow statistics and recession characteristics for the Pomperaug River, Connecticut.

[na, not applicable]

\begin{tabular}{|c|c|c|c|c|c|}
\hline $\begin{array}{l}\text { Pomperaug River } \\
\text { base-flow statistic }\end{array}$ & $\begin{array}{c}\text { PART base-flow } \\
\text { estimate- } \\
\text { observed }\end{array}$ & $\begin{array}{l}\text { PART base-flow } \\
\text { estimate- } \\
\text { simulated }\end{array}$ & $\begin{array}{l}\text { Log residual } \\
\text { simulated- } \\
\text { observed }\end{array}$ & $\begin{array}{c}\text { Recession slope } \\
\text { estimates- } \\
\text { observed }\end{array}$ & $\begin{array}{c}\text { Recession slope } \\
\text { estimates- } \\
\text { simulated }\end{array}$ \\
\hline \multicolumn{6}{|c|}{ Daily } \\
\hline Mean & 79 & 76 & 0.006 & -0.22 & -0.19 \\
\hline Standard deviation & 63 & 54 & 0.196 & 0.11 & 0.08 \\
\hline Minimum & 3.6 & 4.9 & -0.708 & -0.04 & -0.07 \\
\hline Maximum & 458 & 536 & 1.373 & -0.56 & -0.44 \\
\hline Nash-Sutcliffe coefficient & na & 0.72 & na & na & na \\
\hline Coefficient of determination $\mathrm{R}^{2}$ & na & 0.72 & na & na & na \\
\hline \multicolumn{6}{|c|}{ Monthly } \\
\hline Mean & 79 & 76 & 0.013 & na & na \\
\hline Standard deviation & 56 & 46 & 0.181 & na & na \\
\hline Minimum & 4.7 & 6.4 & -0.588 & na & na \\
\hline Maximum & 230 & 179 & 0.776 & na & na \\
\hline Nash-Sutcliffe coefficient & na & 0.80 & na & na & na \\
\hline Coefficient of determination $\mathrm{R}^{2}$ & na & 0.81 & na & na & na \\
\hline
\end{tabular}

Table 13. Estimated average annual recharge in the Pomperaug River watershed, Connecticut.

\begin{tabular}{lccc}
\hline & $\begin{array}{c}\text { Simulated assuming a 1 percent coarse } \\
\text { glacial stratified deposits 1999-2005 } \\
\text { (inches) }\end{array}$ & $\begin{array}{c}\text { Mazzaferro } \\
\text { (1986) } \\
\text { (inches) }\end{array}$ & $\begin{array}{c}\text { Starn and others } \\
\text { (2000) } \\
\text { (inches) }\end{array}$ \\
\hline Till & 8 & 8 & 9 \\
Coarse stratified drift & 24 & 22 & 24 \\
\hline
\end{tabular}

Table 14. Simulated runoff data for South Brook (three hydrologic response units), Connecticut, July 1-11, 2004.

[HRU, hydrologic response unit]

\begin{tabular}{lcccc}
\hline \multicolumn{1}{c}{ Watershed position } & $\begin{array}{c}\text { Annual groundwater } \\
\text { runoff contribution } \\
\text { (inches) }\end{array}$ & $\begin{array}{c}\text { Annual subsurface } \\
\text { runoff contribution } \\
\text { (inches) }\end{array}$ & $\begin{array}{c}\text { Annual surface } \\
\text { runoff contribution } \\
\text { (inches) }\end{array}$ & $\begin{array}{c}\text { Annual total } \\
\text { runoff } \\
\text { (inches) }\end{array}$ \\
\hline Upland-Till dominated (HRU 37) & 5.9 & 8.1 & 7.1 & 21.1 \\
Transition-Till and coarse stratified drift (HRU 38) & 10.7 & 8.6 & 2.5 & 21.8 \\
Valley-Coarse stratified drift (HRU 39) & 21.6 & 0.0 & 1.9 \\
\hline
\end{tabular}




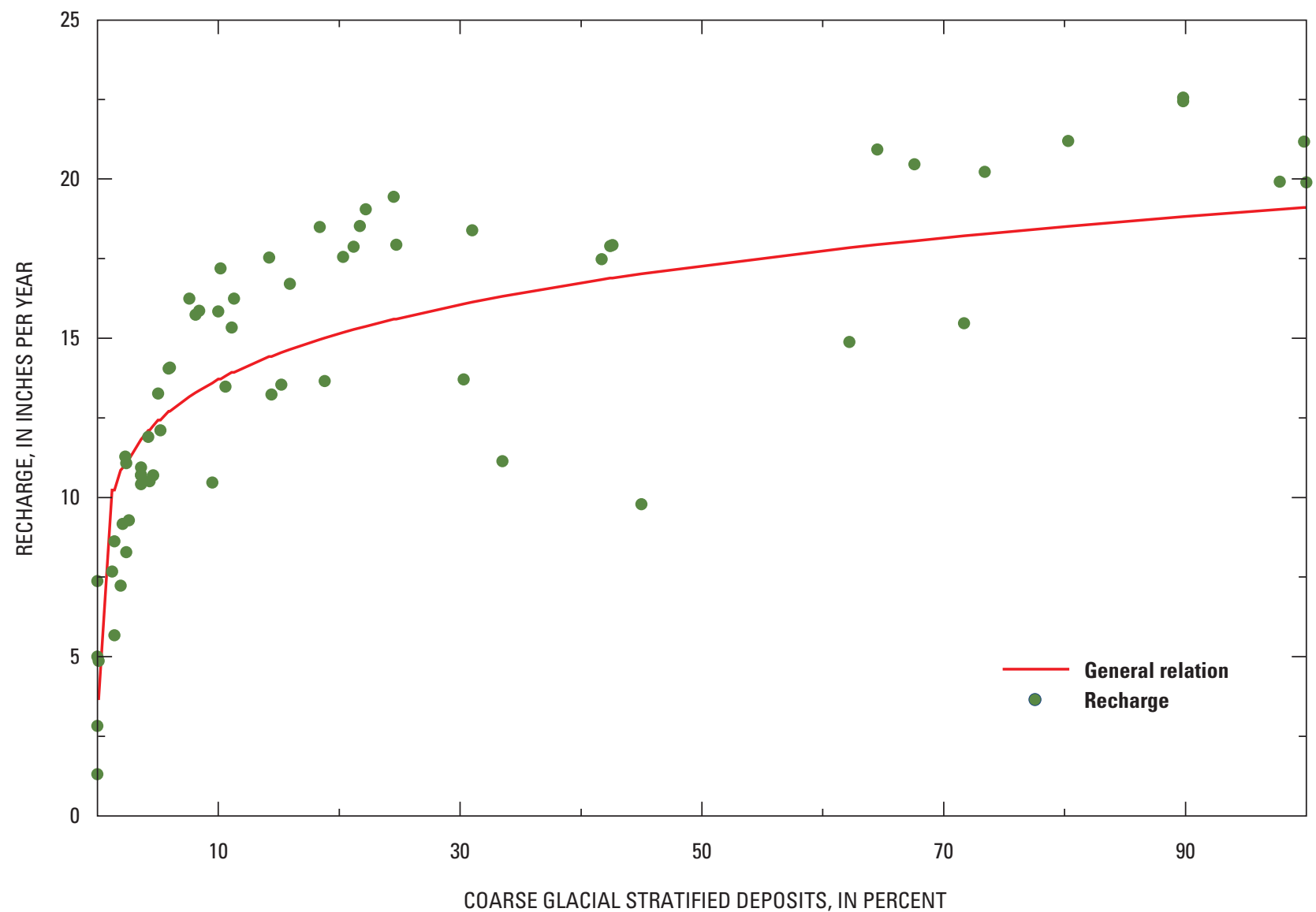

Figure 22. Relation between the percentage of coarse glacial stratified deposits and the simulated average annual recharge in each hydrologic response unit, Pomperaug River watershed, Connecticut. 

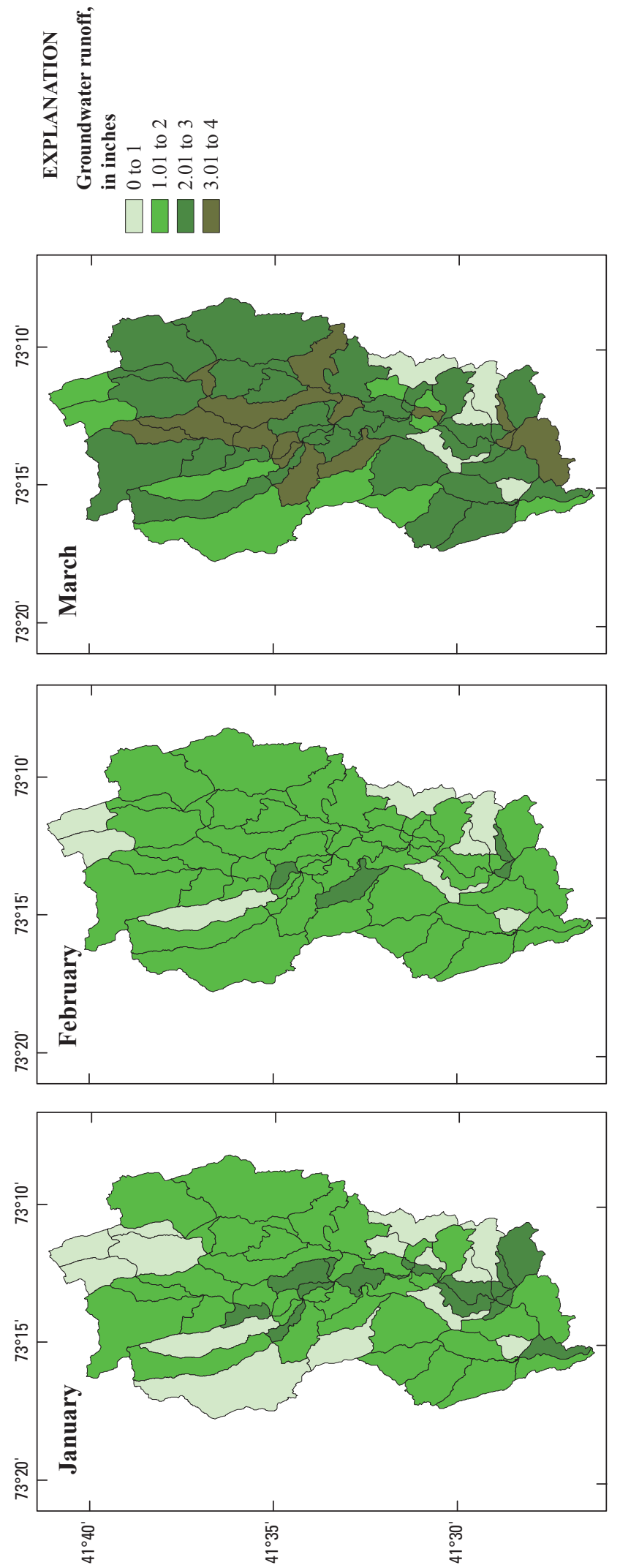
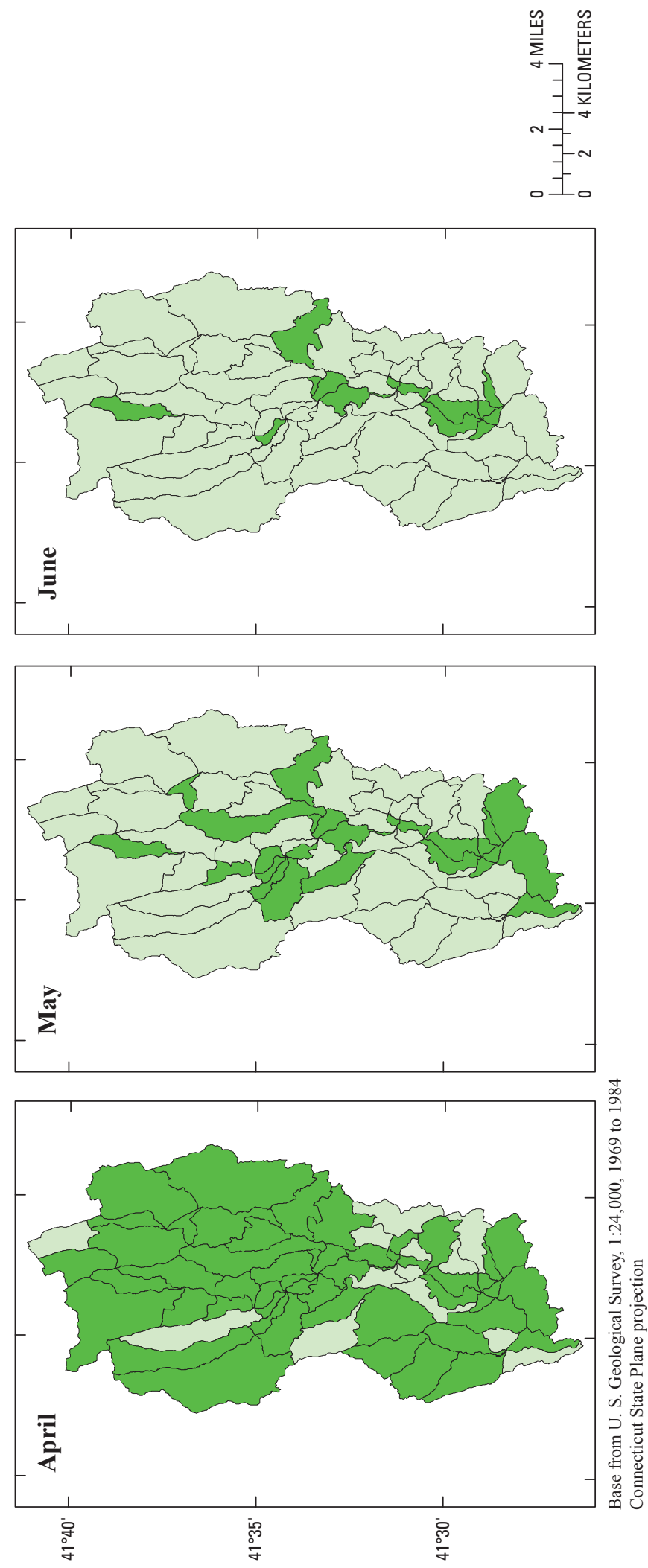

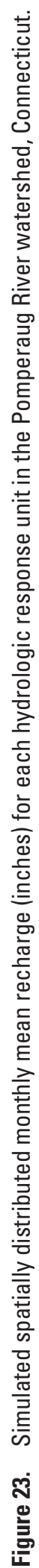




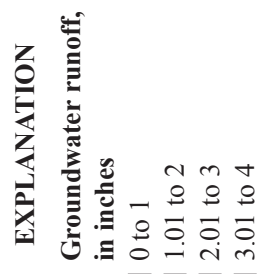

प्या
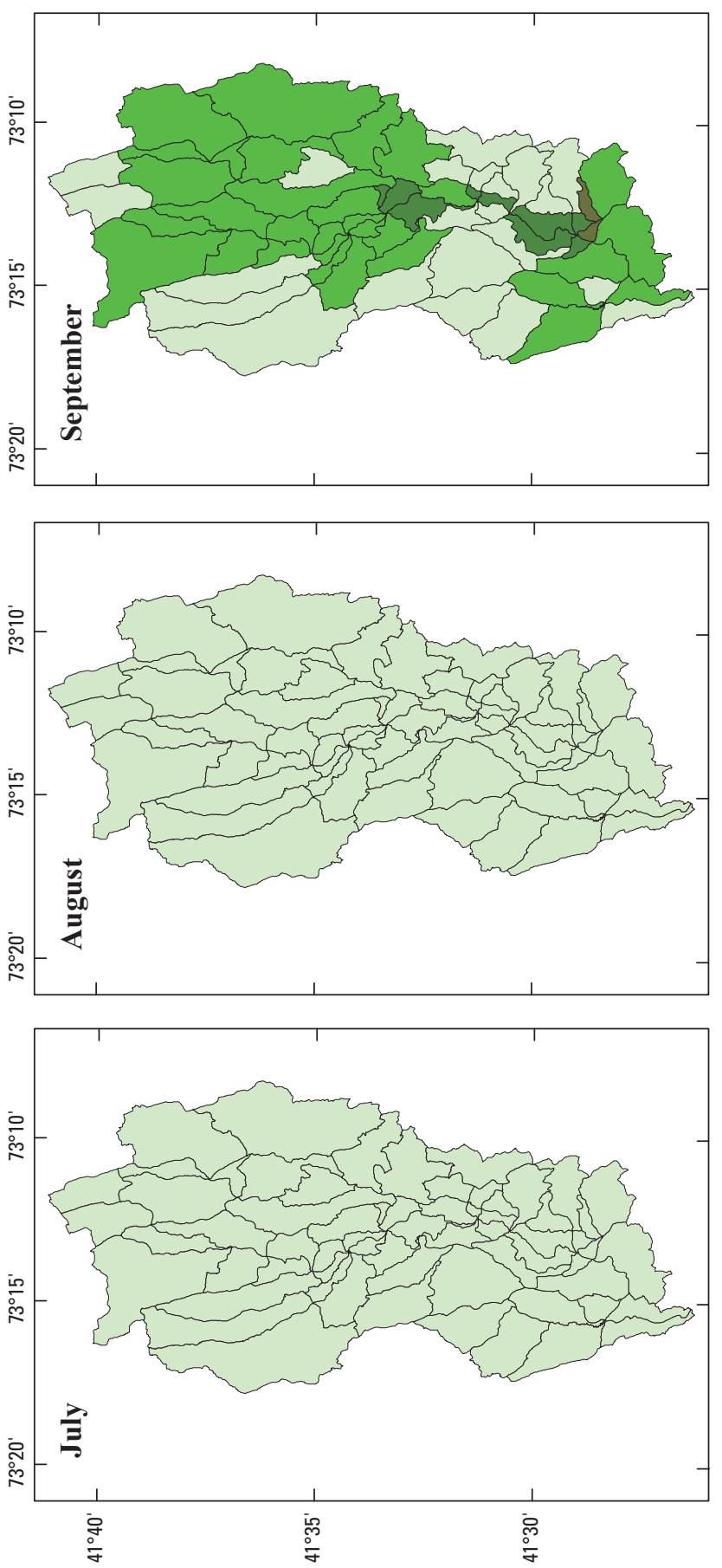
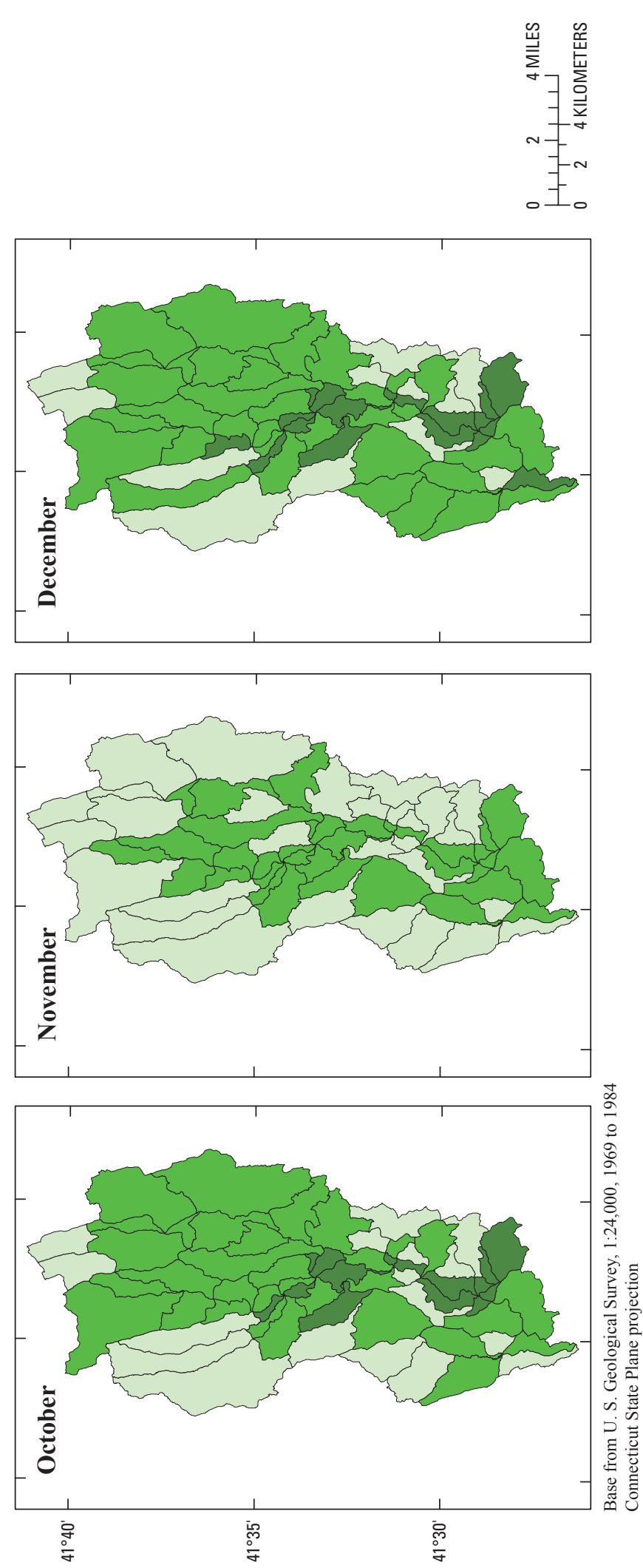

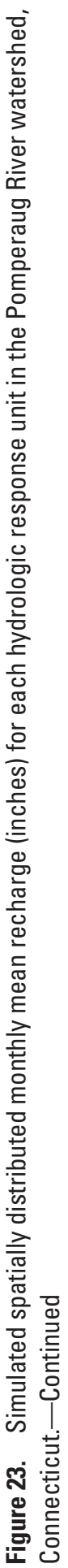



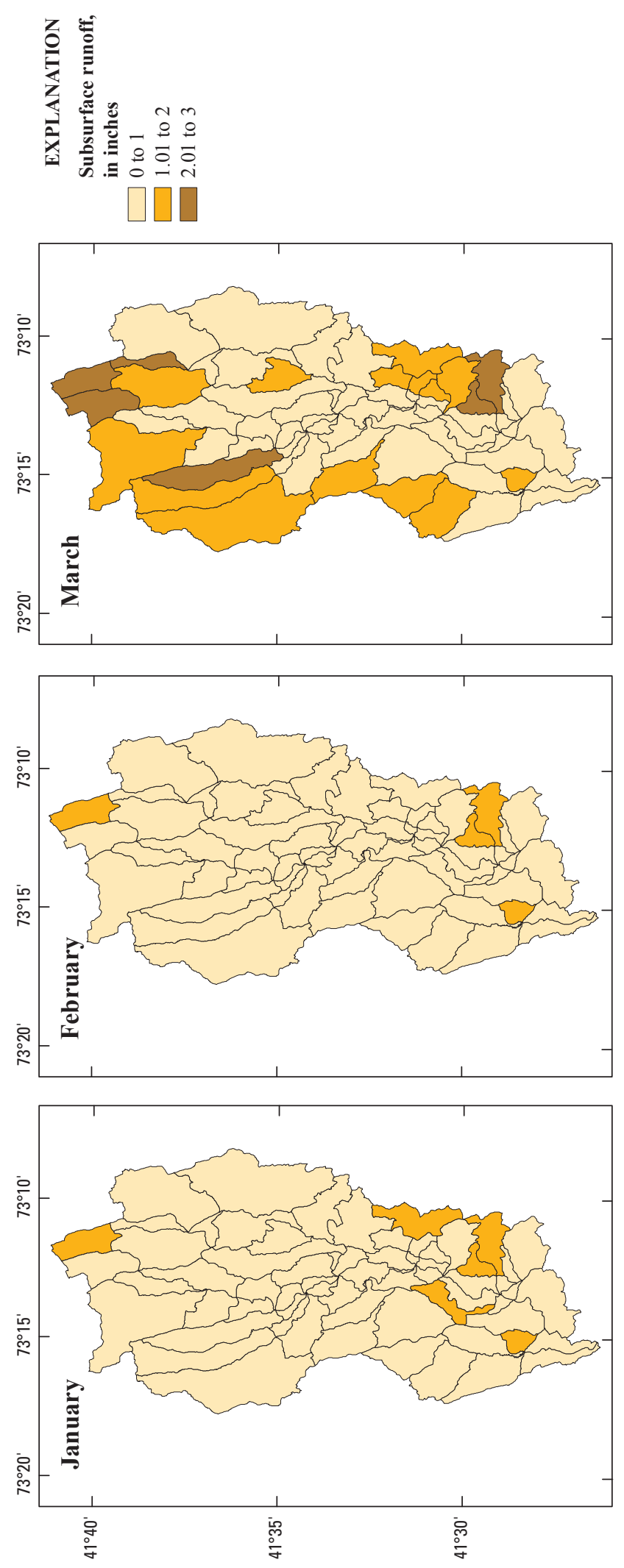
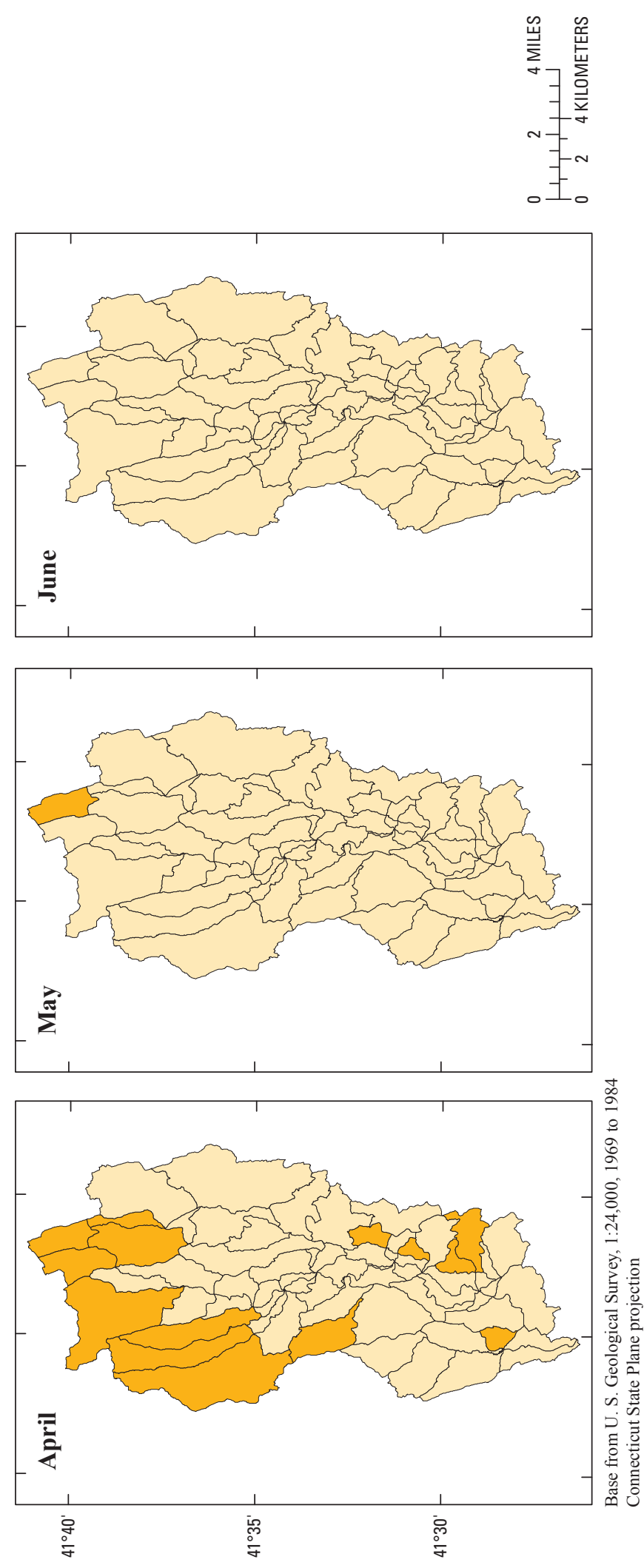

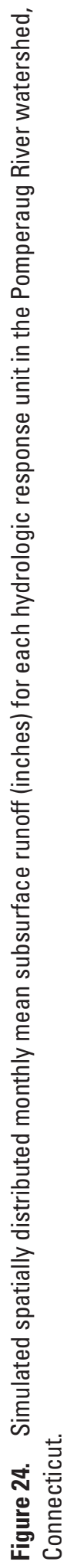



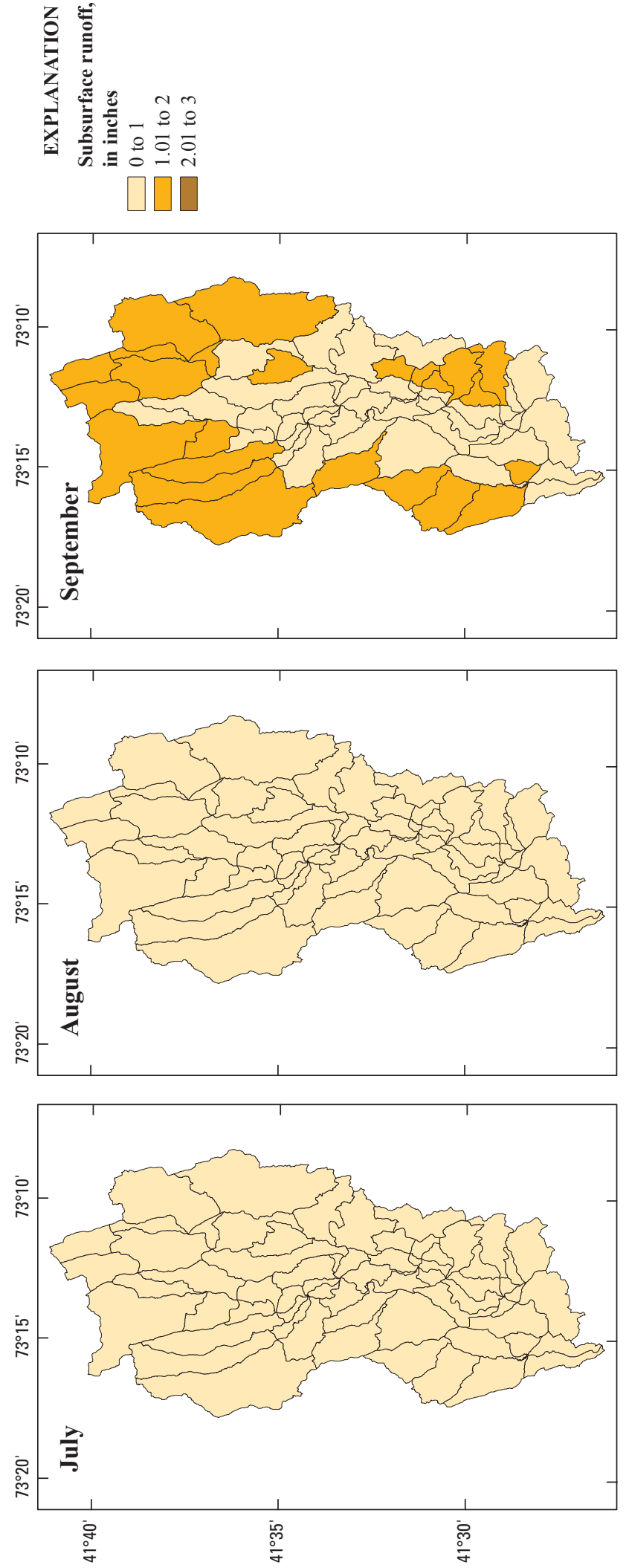
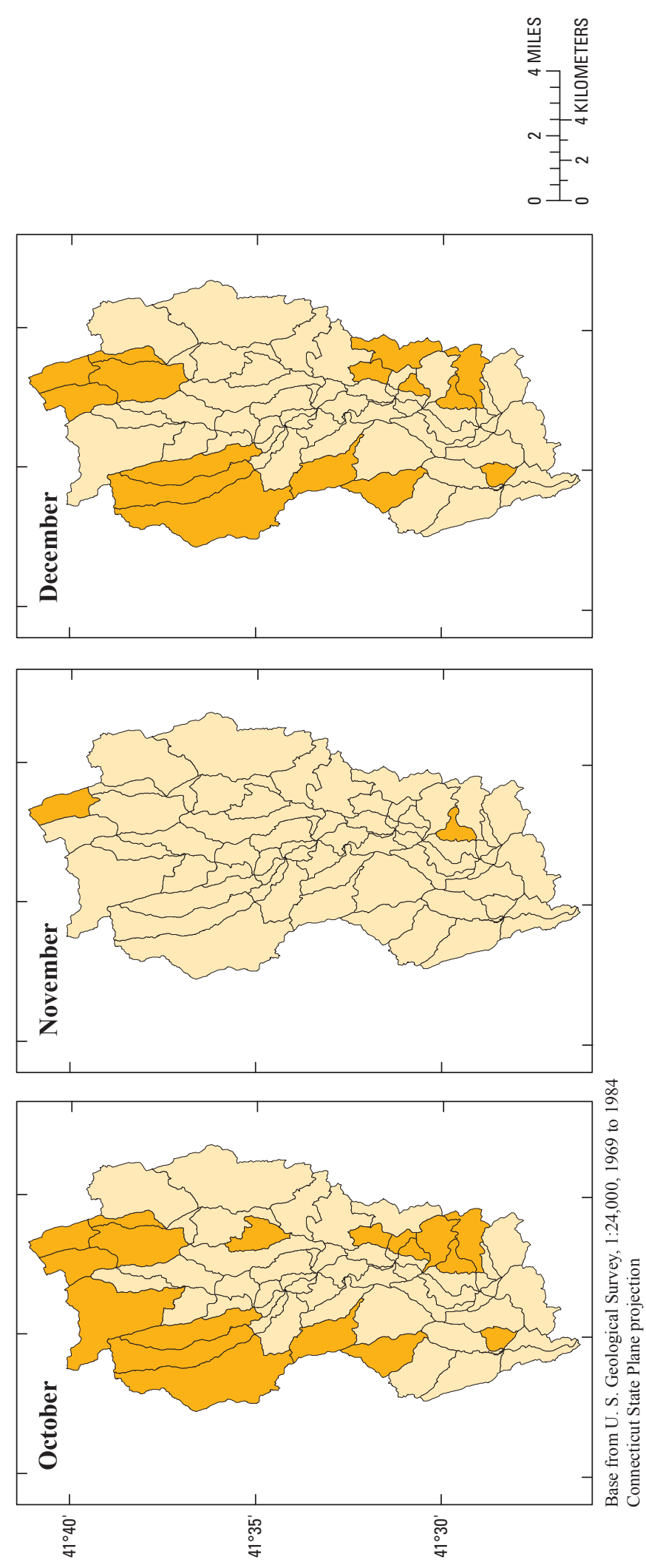

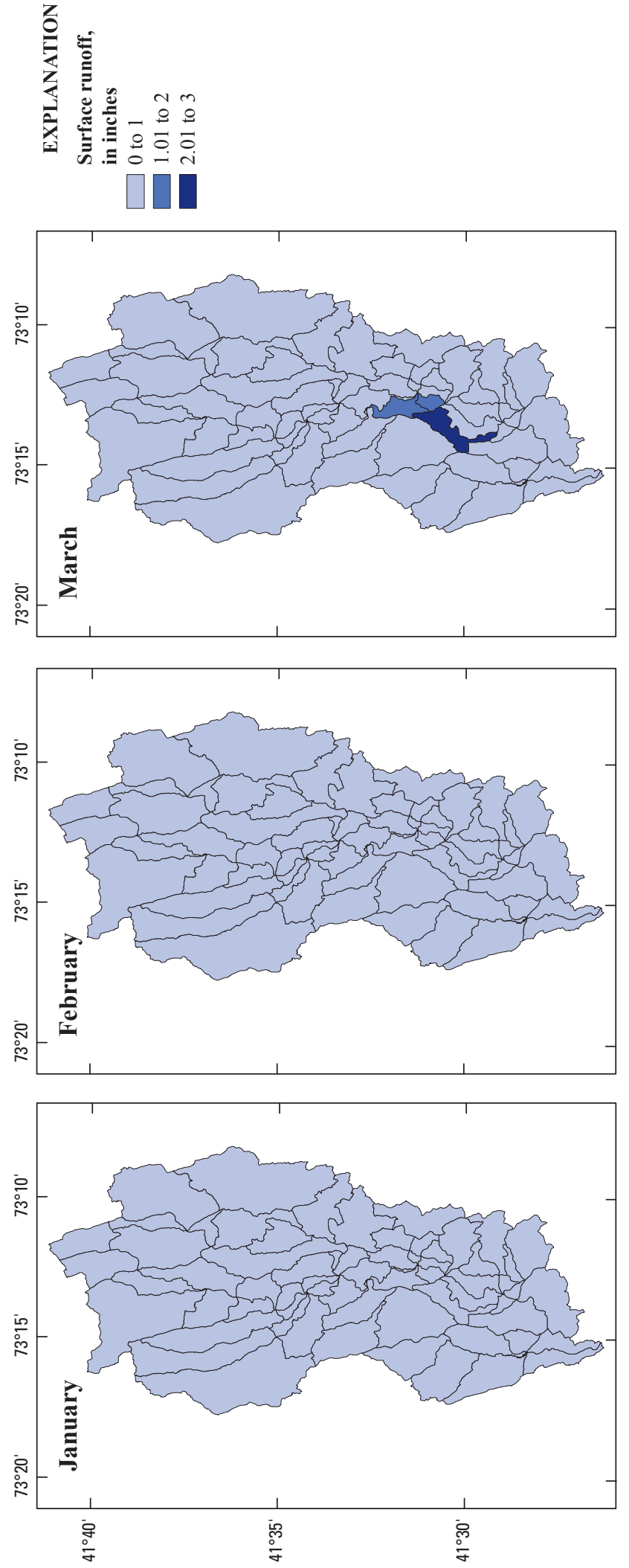
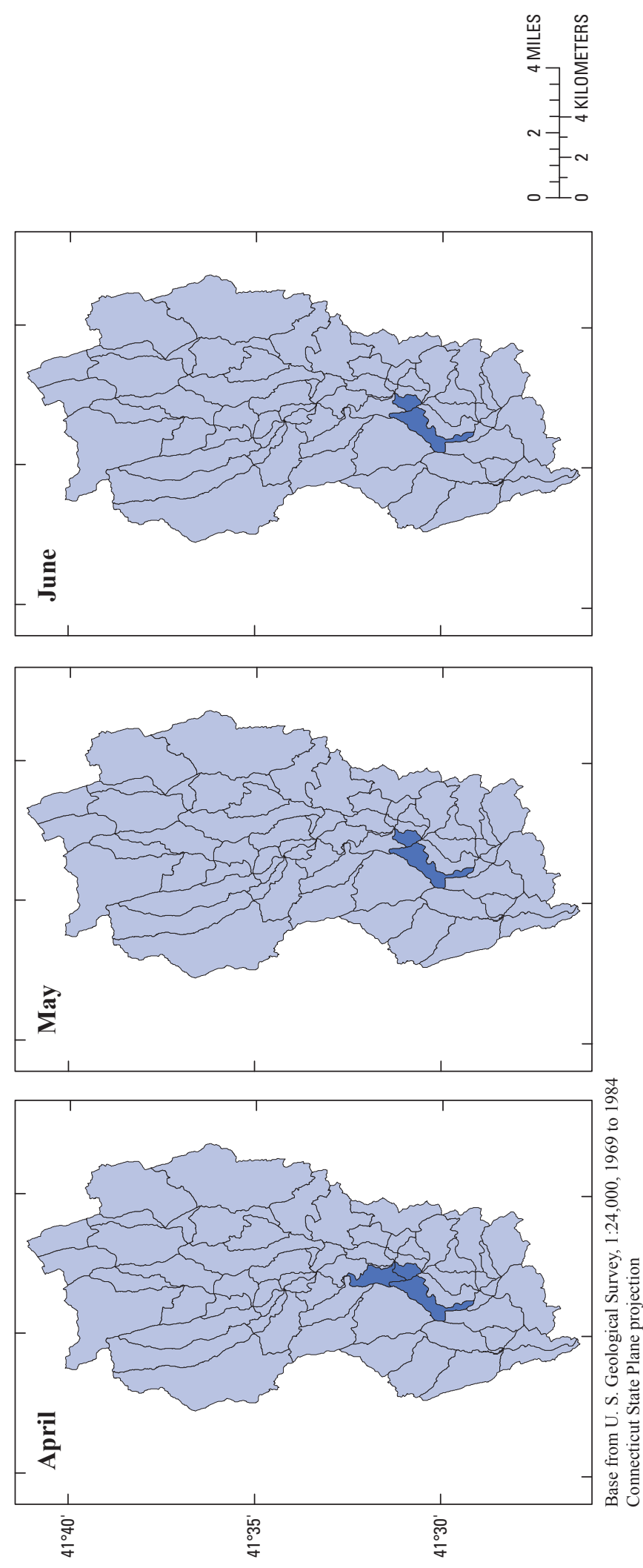

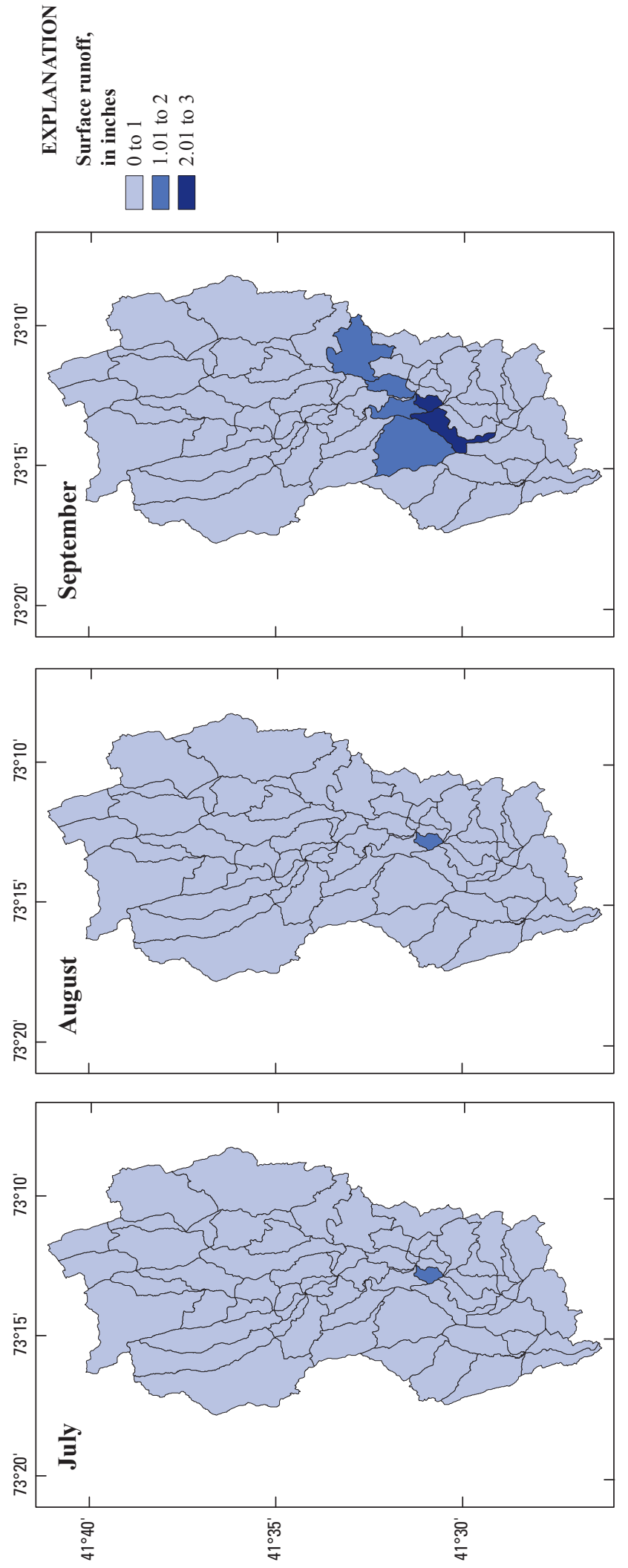
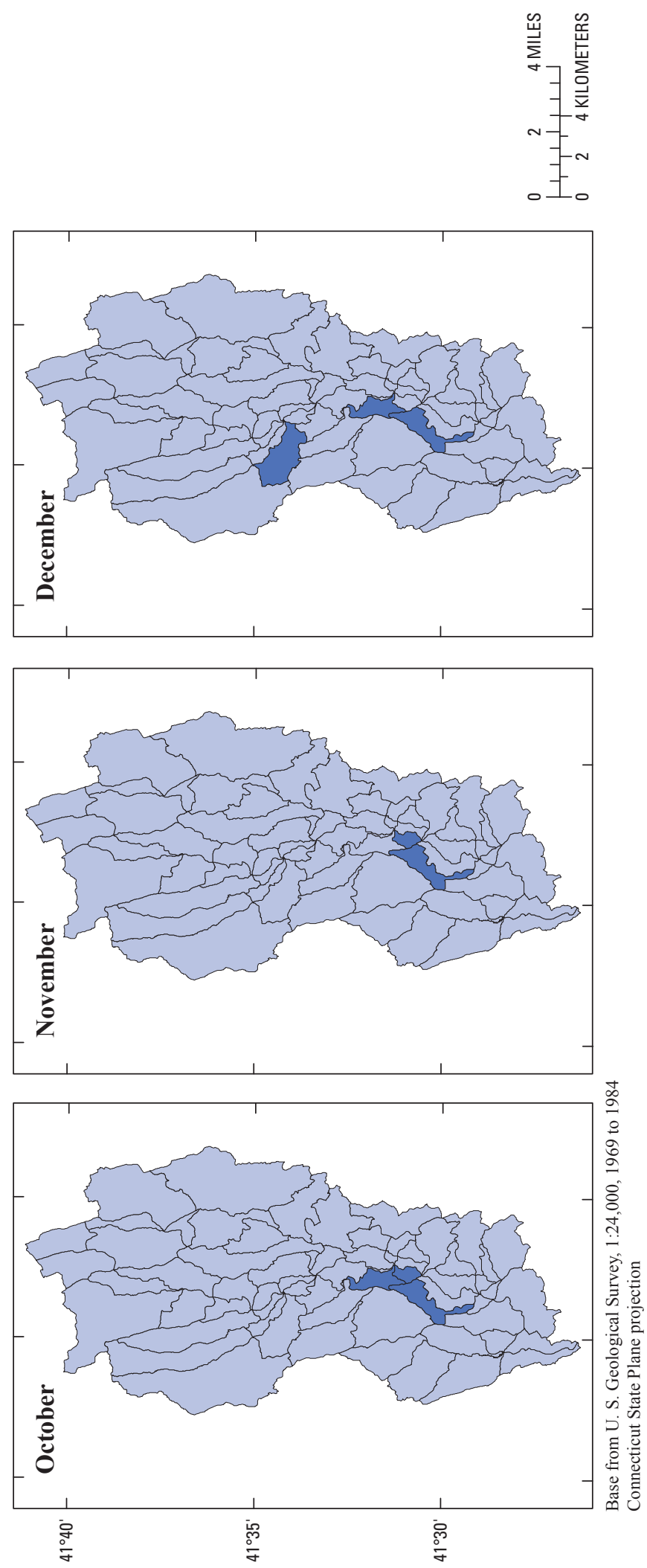

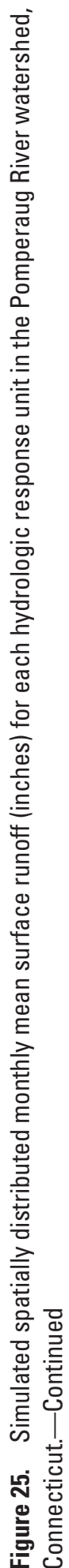




\section{The Groundwater-Runoff Model (MODFLOW)}

A transient model of groundwater flow in the study area was developed using the modular groundwater flow model to help evaluate the effects of groundwater pumping from production wells and land-use change on the spatial variability of base flow to streams. Groundwater flow was simulated using the computer program MODFLOW-2000 (Harbaugh and others, 2000; Hill and others, 2000), which uses a finitedifference method to simulate 3-dimensional groundwater flow through a porous medium. MODFLOW-2000 uses a non-linear regression technique to estimate parameter values that result in the best match between observed and simulated values. This model, when combined with boundary and initial conditions, describes 3-dimensional groundwater flow in a heterogeneous and anisotropic medium, provided that the principal axes of hydraulic conductivity are aligned with the coordinate directions.

\section{General Description of MODFLOW Developed for the Watershed}

The MODFLOW model was initially developed as a steady-state groundwater flow representation for the Pomperaug River watershed as part of the USGS National Water Quality Assessment (NAWQA) Program (Lyford and others, 2007; Starn and Brown, 2007). The modeled area included most of the Pomperaug River watershed (approximately $50 \mathrm{mi}^{2}$ ) except the Weekeepeemee River watershed (Lyford and others, 2007). The model represents general hydraulic conditions that existed from 1999 to 2005. Model input includes boundary conditions, model stresses, and hydraulic properties. The model discretized the study area into $500 \times 500 \mathrm{ft}$ cells. The model used the Stream Package (Prudic, 1989) to simulate base flow to the streams and leakage through the streambed and the evapotranspiration package (Harbaugh and others, 2000) to simulate evapotranspiration losses from the groundwater zone (this was not simulated by PRMS). Detailed discussion of the model and model applications can be found in Lyford and others (2007) and Starn and Brown (2007). For this study, the model was run in transient mode to derive daily values of groundwater flow, groundwater levels, and discharge to wells and streams throughout the modeled area. The model was driven by daily recharge input derived from the PRMS model output.

\section{Representation of the Watershed-Hydrogeology}

Detailed discussion of geologic and hydrogeologic conditions in the watershed is found in Lyford and others (2007), Starn and Brown (2007), Mazzaferro (1986a, 1986b), and Meinzer and Stearns (1929). Lyford and others (2007) developed a groundwater-flow model (herein called the original model). Starn and Brown (2007) modified the layer thickness, recharge, and parameter estimates from the original model in order to incorporate information that became available after the model was completed and to simulate transient conditions.

The original model simulated an area surrounded by a no-flow (zero-flux) boundary, which assumes that groundwater divides are coincident with topographic divides, inflow to the modeled area as underflow from three tributary watersheds is negligible, and underflow at the mouth of the Pomperaug River is negligible. Two layers that parallel the land surface were selected to represent the vertical dimension. Layer 1 is approximately $150 \mathrm{ft}$ thick and represents till and shallow bedrock in upland areas and stratified, glacially derived course glacial stratified deposits and shallow bedrock in the valleys. Layer 2 represents a section of bedrock approximately $350 \mathrm{ft}$ thick. It is assumed that most groundwater flows through a total thickness of about $500 \mathrm{ft}$.

Hydraulic-conductivity zones for each layer of the original model were defined on the basis of the mapped distribution of geologic units and saturated thicknesses presented by Grady and Weaver (1988). Layer-1 zones included surface till and thick till zones in uplands and four zones in glacial coarse glacial stratified deposits that fill the valley. The zones for valley-fill materials are defined largely on the basis of saturated thickness of sand and gravel and are best visualized as transmissivity zones rather than hydraulicconductivity zones because layer-1 thickness generally is greater than actual geologic-unit thickness. These zones included (1) areas along the valley wall where the saturated thickness is less than $10 \mathrm{ft},(2)$ areas where the saturated thickness is 10 to $50 \mathrm{ft}$, (3) areas where the saturated thickness is greater than $50 \mathrm{ft}$, and (4) a fairly extensive area near North Woodbury where coarse materials overlie fine materials (fig. 6.8 in Lyford and others, 2007). The hydraulicconductivity zones for layer 2 included one for Paleozoic crystalline rocks and a second for the more transmissive Mesozoic rocks.

Changes to layer thickness in the original model were necessary because that model represented a combination of glacial stratified deposits and bedrock in a single layer. In the current modified model, the upper layer was subdivided into three layers, and the lower layer, which represents only bedrock, was left as one layer. The model also was modified by using a more detailed representation of groundwater recharge derived from daily, spatially distributed values for each HRU, discussed previously. Other minor changes were made in the modified model, such as using a more accurate estimate of bedrock elevation. The different layering changed the geohydrologic-unit definition, and an accurate estimate of groundwater flow could be obtained only by re-estimating model parameters. The re-estimation was done using the parameterestimation capability available in MODFLOW-2000 and the same set of calibration data used in the original calibration. These modifications resulted in slightly different aquiferproperty estimates. 


\section{Streams, Transient Recharge, Pumping, and Diversions}

Model stresses include streams, recharge, and extraction wells. Perennial streams were simulated using the MODFLOW stream package (Prudic, 1989). The stream package accounts for gains and losses in the simulated streams and routes flow from upstream reaches to downstream reaches. The ends of stream segments were placed at mapped stream origins in headwater areas, at stream intersections, and at major changes in stream-channel slope. The stream elevations were interpolated linearly within a segment. This approach closely matched actual stream elevations at stream reaches for low-gradient, uniformly sloped main stems, but was less accurate for tributary streams with high-gradient, non-uniform slopes. The Nonnewaug, Weekeepeemee, and Pomperaug Rivers were assumed to be $50 \mathrm{ft}$ wide except near the Watertown Fire District wells where a 100-ft width was assigned to account for diversions from the Nonnewaug River through the recharge ponds. All other streams were assumed to be $10 \mathrm{ft}$ wide. A streambed hydraulic conductivity of $1.0 \mathrm{ft} / \mathrm{d}$ was assumed for all streams on the basis of literature-reported values (Kontis and others, 2004).

Recharge was applied as daily input values distributed by HRU across the watershed. Each model cell $(500 \times 500 \mathrm{ft})$ was assigned a recharge value depending on the HRU where it was located. Discharge wells were placed at locations of publicsupply wells completed in sand and gravel and bedrock. The locations of these wells are shown in Lyford and others (2007). Current monthly pumping rates for the wells used in the MODFLOW model are shown on table 15. The extraction rates used were set to observed or estimated average rates for the year (annual column of table 15).

\section{Calibration and MODFLOW Simulation Results}

The MODFLOW model was initially calibrated by Lyford and others (2007) and modified by Starn and Brown (2007). The current model relied on these previous calibrations, with the addition of time-variant recharge in transient mode. The best low-flow results were achieved using the evapotranspiration package turned on in the model. This package allows for additional water losses from the groundwater reservoir from areas where the water table approaches the land surface. The model assumes that groundwater is available for evapotranspiration when the water table comes within $4 \mathrm{ft}$ of the ground surface in the model. The simulation assumes that evapotranspiration begins in mid-April and ends in midOctober, similar to the PRMS simulation. When evapotranspiration is active, a maximum rate of $0.005 \mathrm{ft} / \mathrm{d}$ was specified, based on an approximation of the net precipitation minus streamflow in the Pomperaug River watershed. This rate was decreased linearly from land surface (maximum) to $4 \mathrm{ft}$ (the extinction depth), where the rate was zero. Therefore, the position of the water table with respect to land surface determined the rate of evapotranspiration used in the model. The water table in most places is deeper than $4 \mathrm{ft}$, and simulated evapotranspiration generally occurs near groundwater discharge locations, particularly streams and wetlands.

Inclusion of the evapotranspiration process in MODFLOW was necessary in order to simulate steep recessions observed in the streamflow record; no reasonable combination of hydraulic conductivity or storage changes could simulate the observed phenomenon. The extinction depth was based on an estimate of the average rooting depth in the Pomperaug River watershed. For comparison, in a groundwater model in Massachusetts, DeSimone (2004) used a maximum rate of $0.007 \mathrm{ft} / \mathrm{d}$ and an extinction depth between 2 and $6 \mathrm{ft}$. DeSimone (2004) found the model to be moderately sensitive to the maximum evapotranspiration rate.

The MODFLOW-generated evapotranspiration is an additional loss not accounted for by PRMS. These results indicate the PRMS representation of evapotranspiration, although providing good results across the basin, may not adequately account for localized evapotranspiration from saturated ground in riparian zones near streams and other groundwater discharge locations. This finding suggests the need for more localized spatial representation of evapotranspiration in HRUs when trying to model groundwater/surface-water interactions and is also evidence for the need to couple watershed and groundwater processes at comparable scales. Because the PRMS water balance is not preserved in MODFLOW, the quantitative results of MODFLOW can only be considered comparatively accurate. However, the relative effects of changes in pumping and land use on base flow to streams, as determined by MODFLOW, can be appropriately used for interpretive purposes.

\section{Base Flow to Streams}

The PRMS simulations were coupled with MODFLOW by replacing the PRMS groundwater-runoff component with that derived from MODFLOW using the PRMS-generated recharge. The hydrograph was reconstructed by combining the subsurface-runoff and surface-runoff components of PRMS with the groundwater-runoff component simulated by MODFLOW. The reconstructed hydrograph for the Pomperaug River is shown on figures 26A and 26B. At the watershed scale (measured at the Pomperaug streamgage), the PRMS groundwater and subsurface simulations provide base-flow quantity and recession characteristics that are comparable to MODFLOW (fig. 26) because the localized spatial and temporal effects of pumping wells and localized evapotranspiration on groundwater flow are not important. However, because PRMS does not represent groundwater elevations, water-table conditions, and the local effects of groundwater withdrawals and pumping of production wells, it cannot be used to evaluate the spatial and temporal effects of well pumping, stream depletion, and groundwater mounding. This finding indicates that the PRMS groundwater simulation for the Weekeepeemee is a reasonable representation of base 


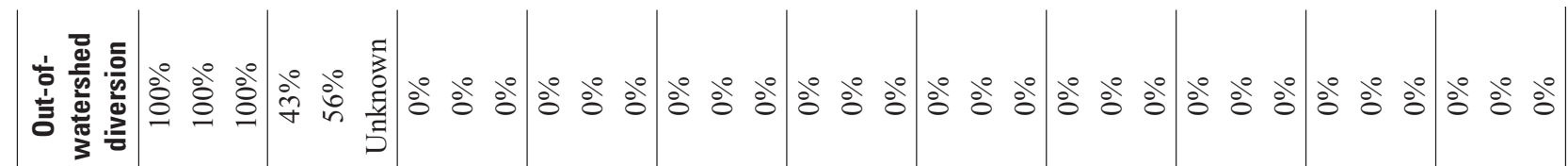

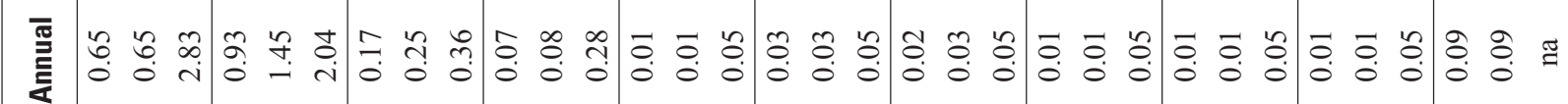

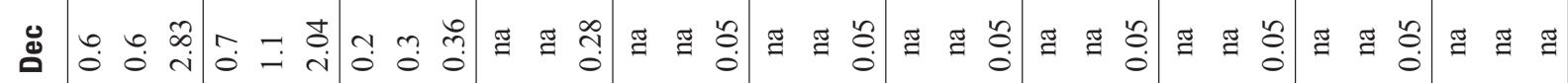

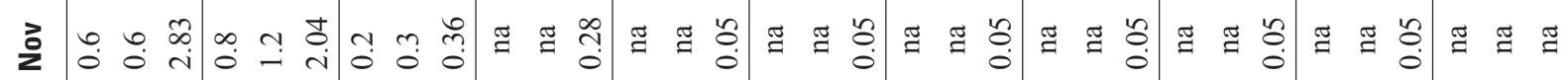

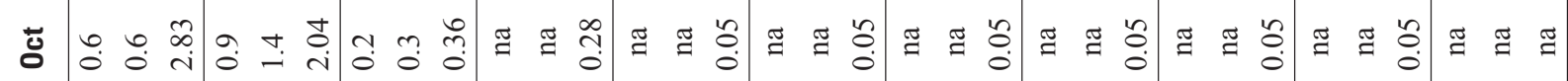

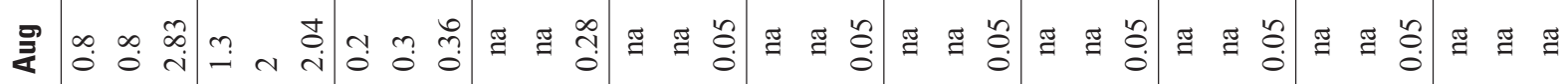

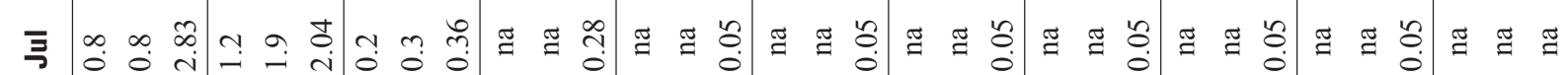

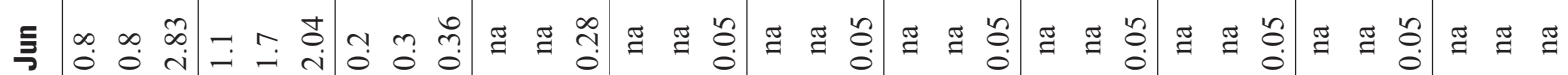

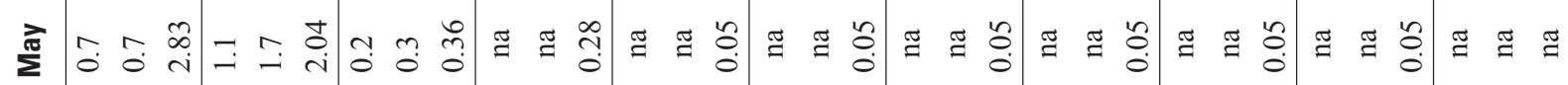

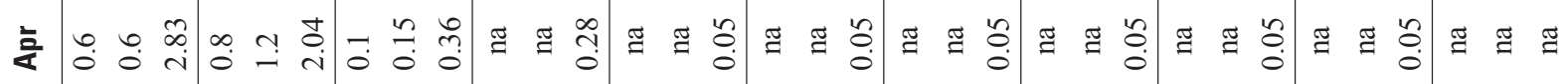

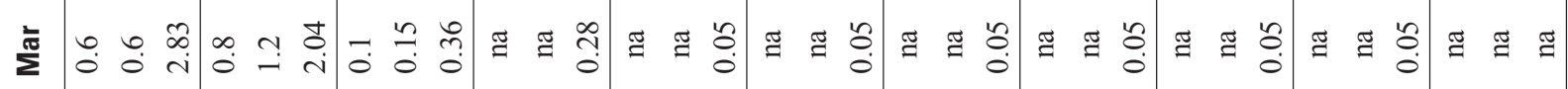
ஓं山

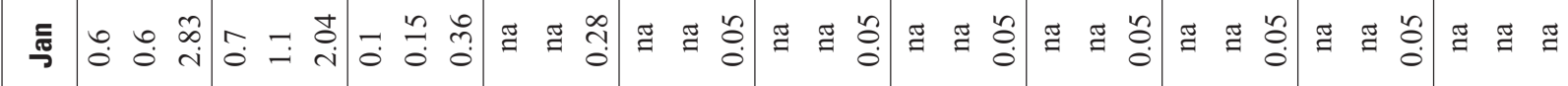
Ф 

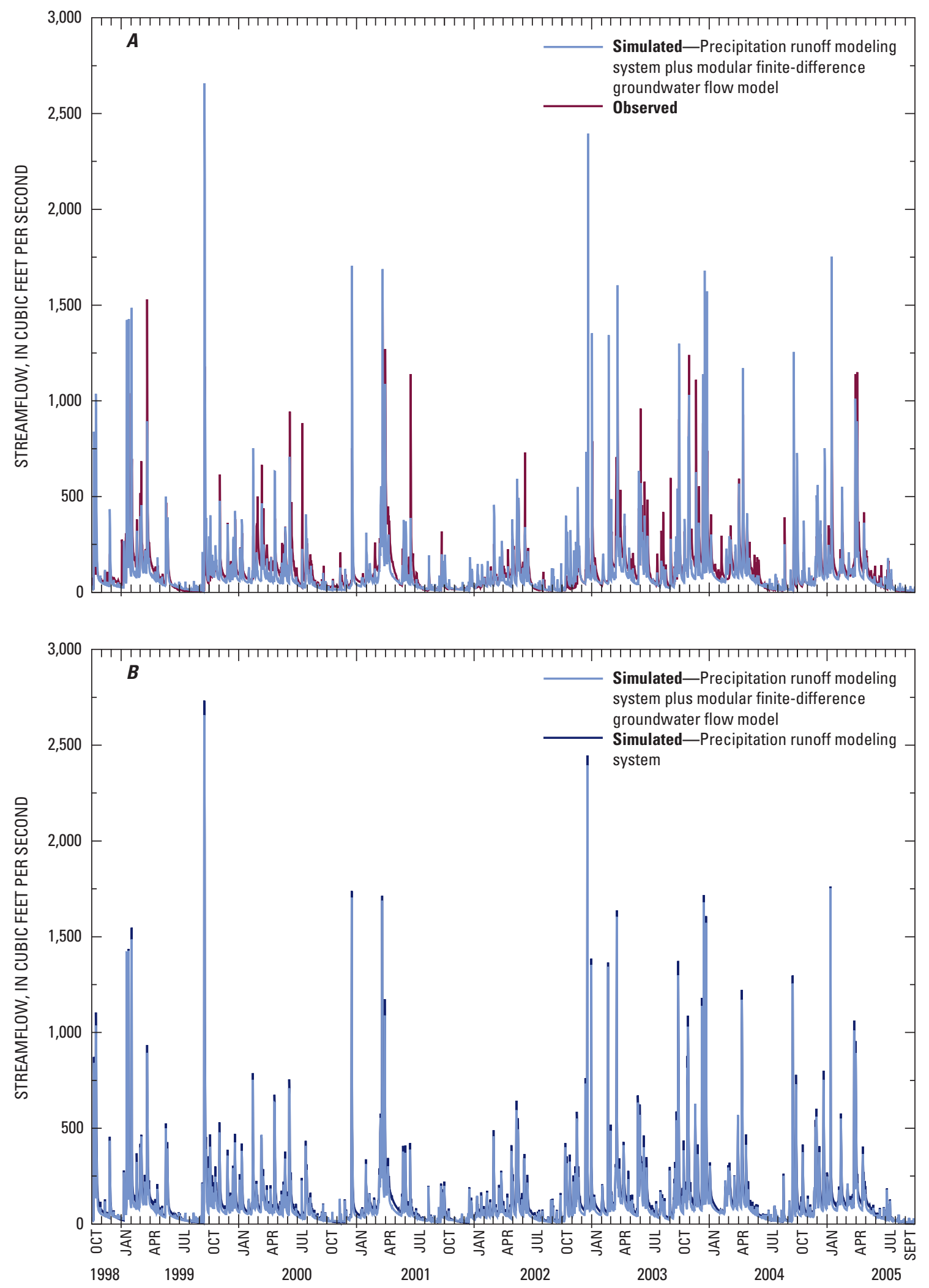

Figure 26. Daily hydrographs of the streamflow in the Pomperaug River at the Southbury streamgage for the period 1999 to 2005 derived by combining the MODFLOW-derived base flow with PRMS-derived subsurface and surface-runoff components showing $(A)$ the PRMS + MODFLOW hydrograph and the observed flow, and $(B)$ the PRMS + MODFLOW hydrograph and the PRMS only hydrograph. 
flow to the stream and can be added to the MODFLOW output to estimate base flows in the Pomperaug downstream from the confluence with the Nonnewaug.

MODFLOW assumes pumped groundwater is not returned to the groundwater system and, therefore, represents a consumptive water use. In fact, pumped groundwater used within the watershed will return eventually to the groundwater system where it is discharged to septic systems or to wastewater-treatment plants within the watershed. Typically, return flows from domestic water use lose approximately 20 percent of the volume to evaporative losses (Solley and others, 1998). However, return flow through septic systems will take a relatively long time to return to the stream. Thus, the assumption that pumped groundwater is 100 percent consumptive is probably a reasonable assumption for consideration of pumping effects during periods of drought.

\section{Losing Reaches}

The MODFLOW model predicted that 22 percent of the stream reaches in the modeled area were losing water through the streambed to the groundwater system at least sometime during the simulation period. This loss generally occurs in smaller tributaries to the Pomperaug River just downstream from the transition from upland areas to the valley bottom. However, some of the losing reaches are short reaches in the mainstem of the Nonnewaug River near its confluence with the Weekeepeemee River and short reaches of the Pomperaug River near Heritage Village and at the dam on South Pomperaug Avenue in Woodbury (Starn and Brown, 2007; Lyford and others, 2007). As an example, the base-flow hydrograph for South Brook simulated by MODFLOW for 1999 through 2005 is shown on figure 27. The hydrograph shows frequent periods when the flow is zero. Observations have shown that South Brook does go dry in the location of the hydrograph simulated on figure 27, although it is not known whether the reach goes dry as often as indicated by the model.

\section{Management Scenario Applications}

The calibrated PRMS model was used to generate simulation data sets of streamflow and component runoff for each HRU on the basis of a set of land and water-use management scenarios outlined by the PRWC. The PRWC and local town governments will use the management-scenario simulation runs to evaluate the temporal and spatial hydrologic effects of different water-use and land-use options so that they can make informed watershed management decisions. The management issues include water availability (groundwater and instream), source-water variability and runoff rates (as it pertains to water quality), and effects of decisions on extreme high-flow and low-flow conditions.

\section{Effects of Land Use and Groundwater Withdrawal on Streamflow}

To evaluate the effects of land use and land cover on streamflow, six land-use scenarios were run including current (2002) conditions, pre-development conditions (no human influence), maximum (full build-out) development that is based on zoning information for the towns within the watershed, all grass (to represent agricultural use and pasture), an arbitrary 10 percent EIA, and an arbitrary 20 percent EIA. The current-condition scenario forms the body of this discussion. An additional pristine-condition scenario assumed a uniform forest land cover for the entire watershed and no reservoirs and assumed a thicker humus layer on the forest floor, which was simulated with a slight increase to the soil storage volume. This scenario provides a reference or baseline streamflow condition for evaluating instream habitat.

The full build-out scenario was based on a compilation of the zoning regulations completed by the Council of Governments of the Central Naugatuck Valley for each town within the watershed (Virginia Mason, Council of Governments of the Central Naugatuck Valley, written commun., 2006) and assumed a representative percentage of impervious surface associated with the maximum type and areal extent of developable land allowed by the regulations. The current impervious surface in the watershed as a percentage of each HRU and the projected full build-out impervious surface as a percentage of each HRU are shown on figure 28. Two runoff management options were considered with the full build-out scenario. The first uses the Connecticut EIA, as shown on figure 12, assuming generally rural conditions with relatively low connectedness of impervious surfaces and minimal drainage control (minimum stormwater collection). The second runoff management option assumes a developed setting with stormwater collection and discharge to streams and is represented by the Alley and Veenhuis data (1983) shown on figure 12 (maximum stormwater collection). The all-grass and arbitrary 10 and 20 percent EIA scenarios were run for comparative purposes.

In general terms, land-use changes (for example, increasing the amount of impervious surface in the watershed and conversion of agriculture and forested lands) affect the amount of recharge to the groundwater reservoirs and the timing and total amount of streamflow. These effects were quantified for the watershed by comparing hypothetical changes of land use in the watershed to the existing condition (approximately 1 percent EIA), assuming approximately 2 percent impervious surface (full build-out with minimum stormwater collection) to 5 percent (full build-out assuming extensive or maximum stormwater collection), 10 and 20 percent EIA distributed evenly across the watershed, all-forest (pristine) conditions, and all-grass (pasture and agricultural use) conditions. Note that the all-grass scenario does not represent lawns and manicured grass surfaces, because these tend to be more compacted with short grass relative to pasture and agricultural uses. The PRMS-generated 


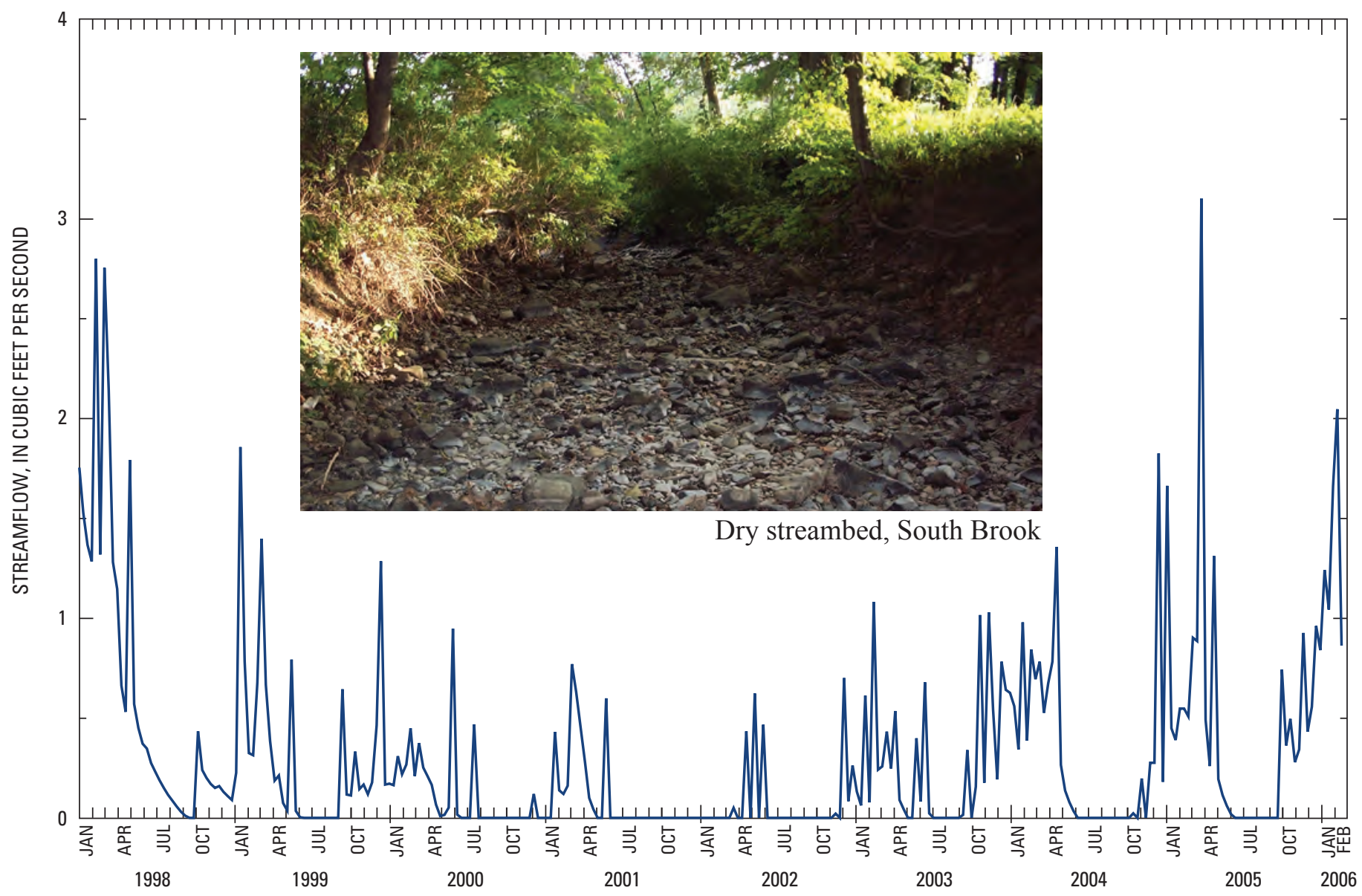

Figure 27. Daily base-flow hydrograph for South Brook near its confluence with the Pomperaug River, Connecticut, showing several periods of no flow in the stream (dry streambed).

effect of these hypothetical land-use/land-cover changes on streamflow at the Pomperaug River streamgage at Southbury are shown on figure 29.

The effect of increasing impervious surface on streamflow statistics is provided on table 16. The simulations indicate that increasing impervious surface up to the maximum allowable by current zoning regulations within the watershed, with EIA estimated using either the relation representing maximum stormwater collection described by Alley and Veenhuis (1983) or by the relation developed in this study representing minimum stormwater collection, would decrease the lowest flows at the Pomperaug streamgage (exceeded 99 percent of the time) by 10 to 14 percent. The effect on higher flows is less. There is little effect on the simulations for the Weekeepeemee and Nonnewaug Rivers, because the potential for development in these watersheds is less. In the future, the portion of the watershed downstream from the confluence of the Weekeepeemee and Nonnewaug Rivers will likely experience the greatest reductions in base flow resulting from development.
The forested watershed has the least amount of total runoff (fig. 29A), because of higher amounts of evapotranspiration, and streamflow increases proportionately to the increase in impervious surface because of reduced evapotranspiration losses. In addition, the timing of runoff is altered because the source of the water in the stream, whether it comes from direct surface runoff, groundwater runoff, or from shallow subsurface runoff, also is altered in response to land-use change.

The transition from a groundwater-runoff to surfacerunoff regime is illustrated on figure $29 \mathrm{~B}$, which shows the total percentage of flow that is either groundwater or surface runoff. Under natural scenarios, including the forest and grass land-cover conditions, groundwater is the dominant source of water in the stream, indicating that mixed land cover (agriculture, meadow grass, and forest) would maintain a river dominated by groundwater, whereas increased development will steadily drive the flow regime to be dominated by surface runoff. Another interesting result is that the all-forest scenario, although showing lower overall runoff (fig. 29A), has the second highest percentage contribution from groundwater; 

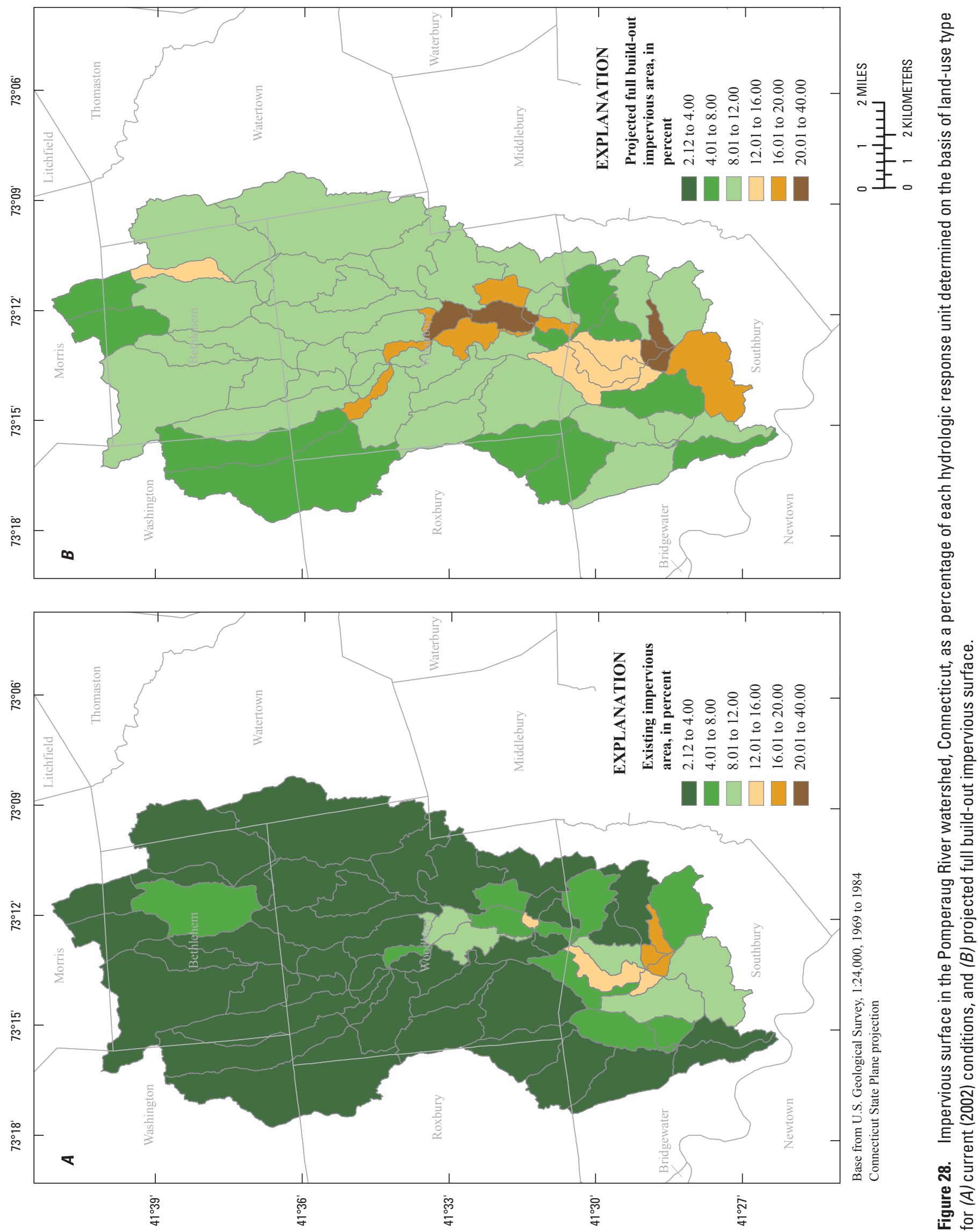

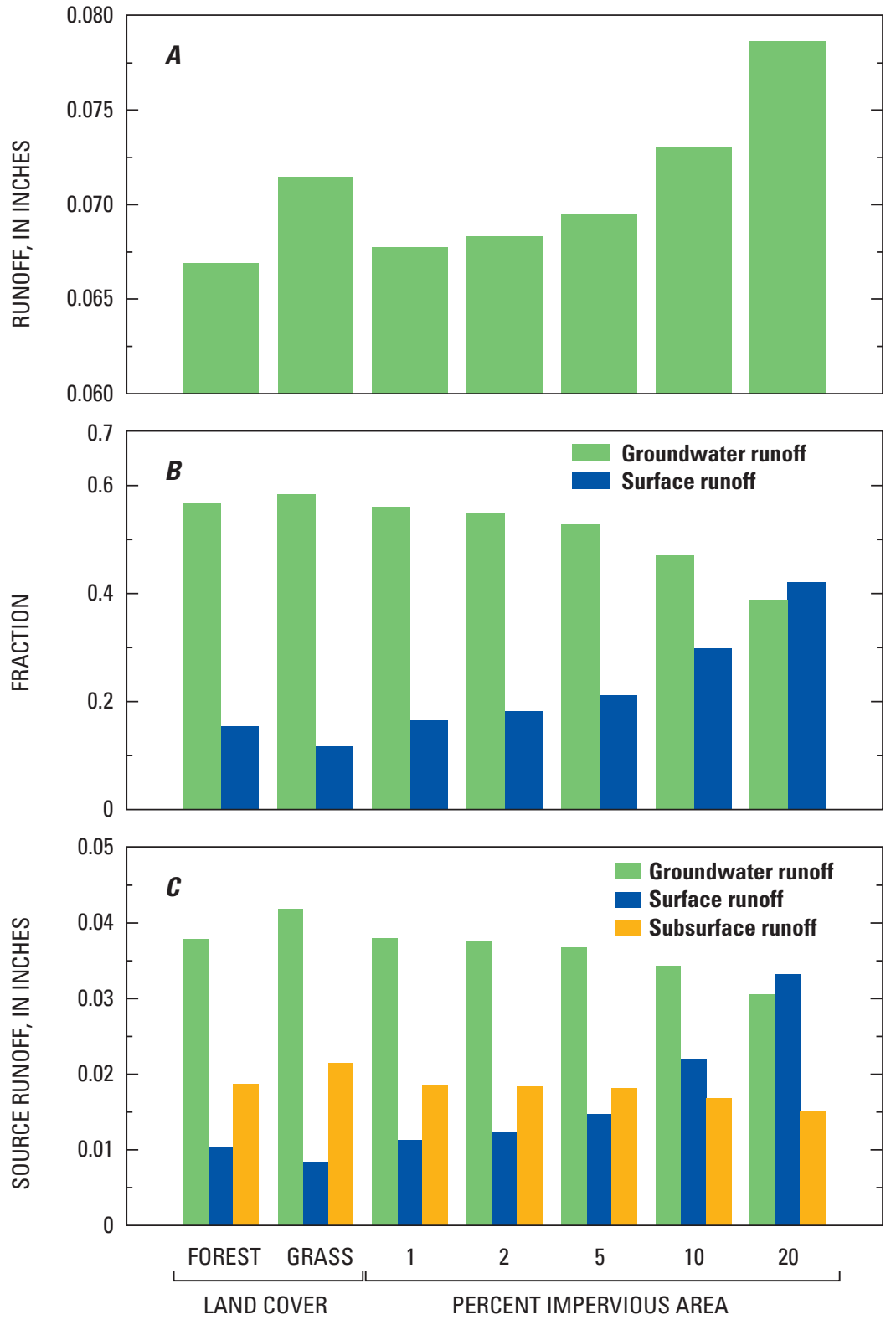

Figure 29. Simulated daily average runoff in the Pomperaug River, Connecticut, as a function of hypothetical land-use change, $(A)$ total streamflow, in inches; $(B)$ percentage of total runoff that is groundwater and surface runoff; and $(C)$ runoff by source (groundwater, subsurface, and surface), in inches. 
Table 16. Simulated streamflow percentiles for different impervious scenarios in the Pomperaug, Weekeepeemee, and Nonnewaug Rivers, Connecticut.

$[\%$, percent $]$

\begin{tabular}{|c|c|c|c|}
\hline \multirow{2}{*}{ Flow percentile } & \multicolumn{3}{|c|}{$\begin{array}{l}\text { Simulated flow value } \\
\text { (cubic feet per second) }\end{array}$} \\
\hline & Existing condition & $\begin{array}{c}\text { Full build-out } \\
\text { Connecticut impervious }\end{array}$ & $\begin{array}{l}\text { Full build-out Alley and } \\
\text { Veenhuis (1983) impervious }\end{array}$ \\
\hline \multicolumn{4}{|c|}{ Pomperaug River } \\
\hline 0.01 - Exceeded $99 \%$ of the time & 7.3 & 6.5 & 6.3 \\
\hline 0.10 - Exceeded $90 \%$ of the time & 17 & 16 & 16 \\
\hline 0.25 - Exceeded $75 \%$ of the time & 41 & 40 & 41 \\
\hline 0.50 - Exceeded $50 \%$ of the time & 82 & 82 & 82 \\
\hline 0.75 - Exceeded $25 \%$ of the time & 144 & 144 & 146 \\
\hline 0.90 - Exceeded $10 \%$ of the time & 262 & 265 & 272 \\
\hline 0.99 - Exceeded $1 \%$ of the time & 917 & 917 & 937 \\
\hline \multicolumn{4}{|c|}{ Weekeepeemee River } \\
\hline 0.01 - Exceeded $99 \%$ of the time & 2.4 & 2.4 & 2.3 \\
\hline 0.10 - Exceeded $90 \%$ of the time & 5.0 & 5.0 & 5.1 \\
\hline 0.25 - Exceeded $75 \%$ of the time & 12 & 13 & 13 \\
\hline 0.50 - Exceeded $50 \%$ of the time & 26 & 27 & 27 \\
\hline 0.75 - Exceeded $25 \%$ of the time & 47 & 48 & 48 \\
\hline 0.90 - Exceeded $10 \%$ of the time & 94 & 94 & 96 \\
\hline 0.99 - Exceeded $1 \%$ of the time & 348 & 356 & 371 \\
\hline \multicolumn{4}{|c|}{ Nonnewaug River } \\
\hline 0.01 - Exceeded $99 \%$ of the time & 0.7 & 0.7 & 0.7 \\
\hline 0.10 - Exceeded $90 \%$ of the time & 2.4 & 2.5 & 2.6 \\
\hline 0.25 - Exceeded $75 \%$ of the time & 7.9 & 8.2 & 8.6 \\
\hline 0.50 - Exceeded $50 \%$ of the time & 19 & 19 & 19 \\
\hline 0.75 - Exceeded $25 \%$ of the time & 35 & 35 & 35 \\
\hline 0.90 - Exceeded $10 \%$ of the time & 65 & 66 & 66 \\
\hline 0.99 - Exceeded $1 \%$ of the time & 245 & 245 & 246 \\
\hline
\end{tabular}


the highest being the all-grass scenario. The all-grass scenario maximizes the total recharge, and the all-forest scenario maximizes the percentage of groundwater contribution compared to developed land cover, indicating that maintaining mixed forest and pasture lands may be important to the sustainability of base flows in a developing watershed.

The quantity of each source component comprising the streamflow for the different land-use conditions is shown on figure 29C. On average for most land-use conditions, groundwater is the dominant source of water in the stream followed by subsurface runoff. However, beginning at 10 percent EIA, surface runoff begins to dominate over subsurface runoff; at 20 percent, surface runoff is the dominant source over both groundwater and subsurface runoff. This transition from a groundwater-dominated flow regime to a surface-runoff flow regime is important for habitat and water quality because of the different chemical and physical characteristics of each water source.
The effect that land-use change has on reducing base flows is shown on figure 30 . As evapotranspiration decreases in response to fewer trees, the amount of groundwater recharge and runoff increases (the all-grass scenario). As evapotranspiration and recharge both decrease because of increasing impervious surfaces, the lowest flows get lower as indicated by the streamflow percentiles on table 16 . The increase in groundwater base flow assuming the all-grass scenario is based on natural infiltration capacity of uncompacted soil and, therefore, is not equivalent to lawns that tend to be more compacted and will shed water more quickly because of the short grass. Conversely, under the full build-out scenario, percent changes in high flows are not substantial.

The relative change in runoff from the three simulated sources as a function of change in EIA is shown on figure 31. Surface runoff increases at a greater rate than the rate at which groundwater runoff and subsurface runoff decrease.

Figure 32 shows the average percentage change in recharge

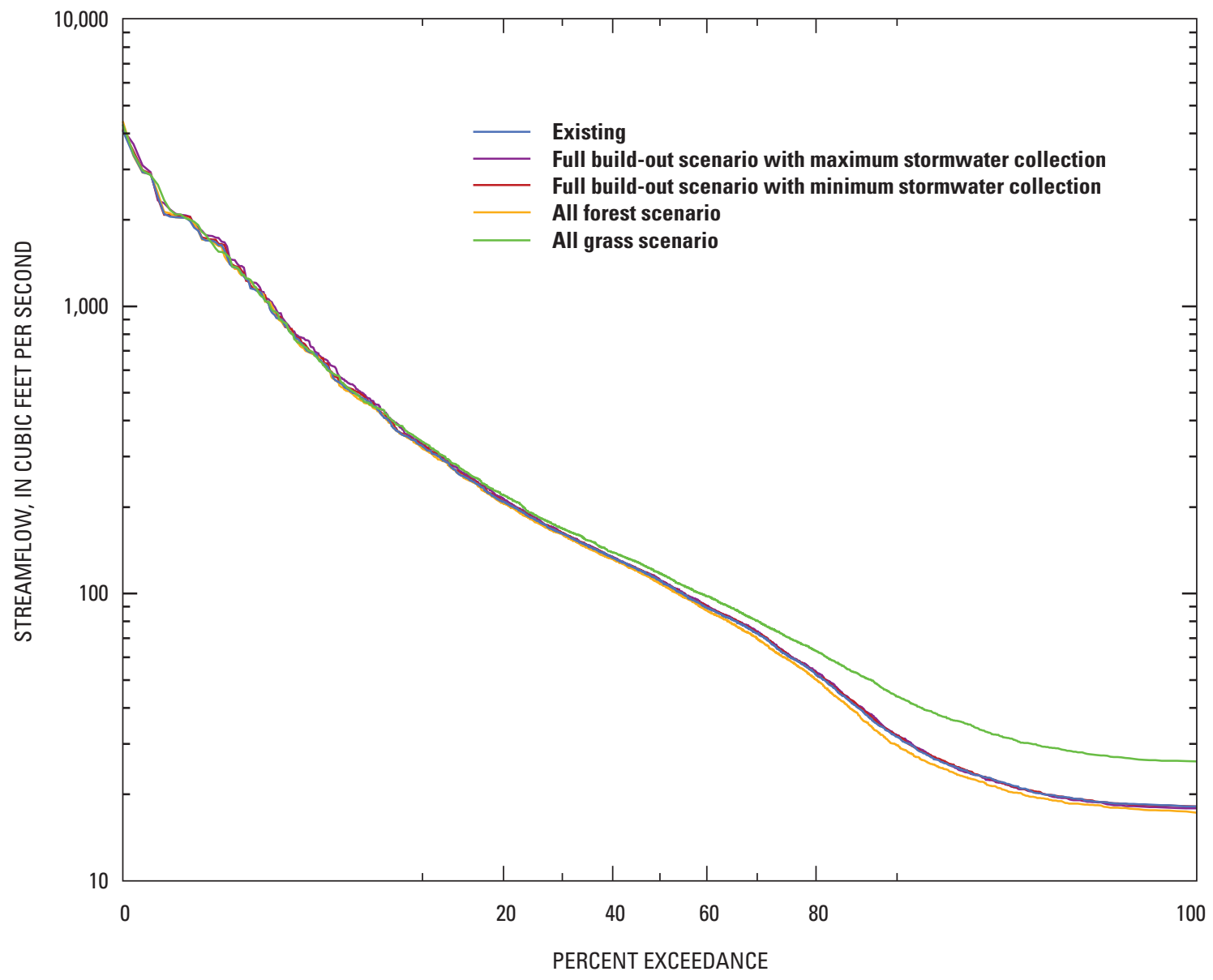

Figure 30. Probability of daily flow rate exceeded in the Pomperaug River at Southbury on any given day as a function of hypothetical land-use scenario in the watershed. 

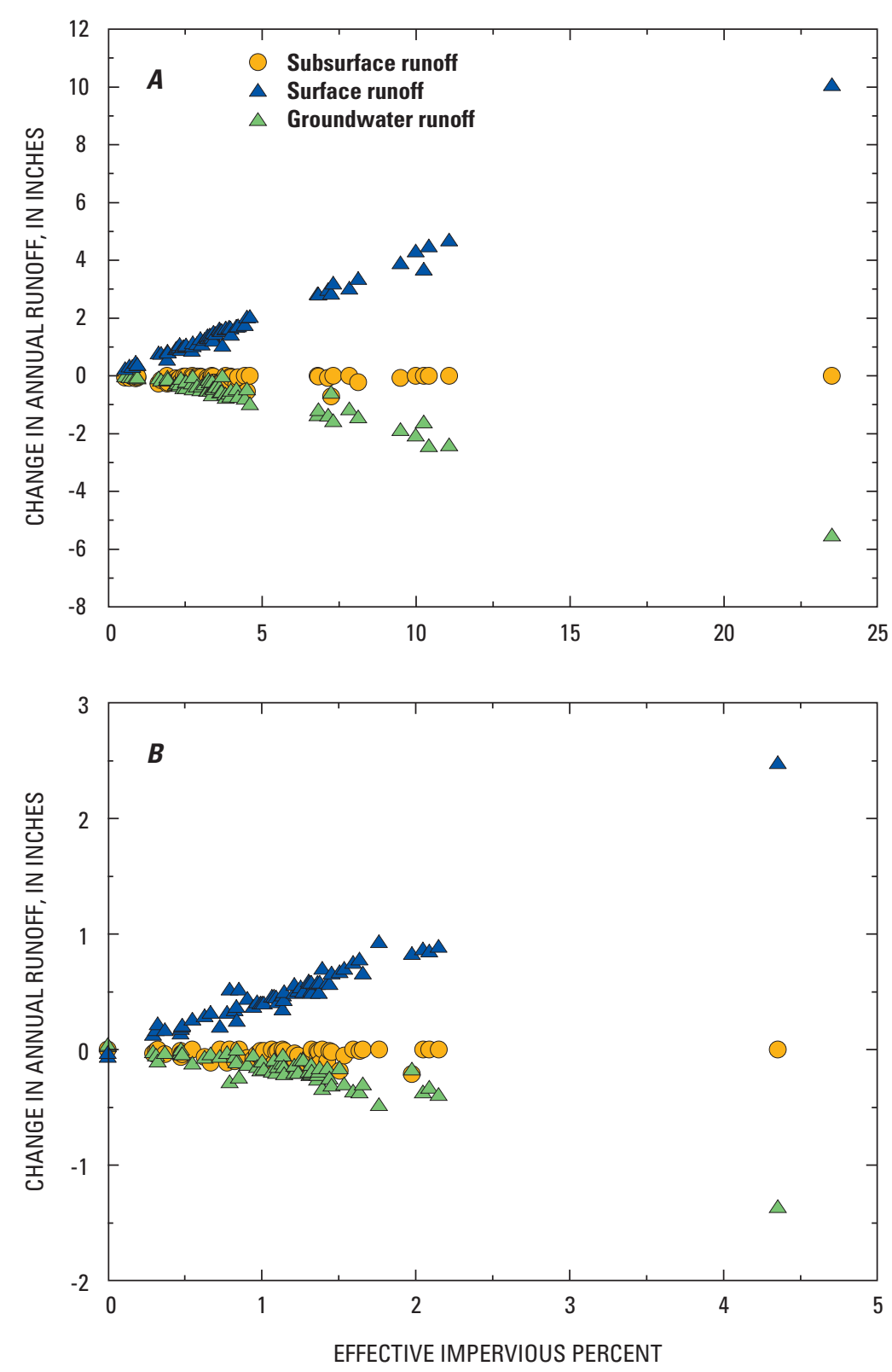

Figure 31. Change in groundwater runoff, subsurface runoff, and surface runoff as a function of change in effective impervious surface for the two full build-out scenarios with $(A)$ maximum and $(B)$ minimum stormwater collection relative to existing conditions for the Pomperaug River at Southbury, Connecticut. by HRU over the simulation period for the two full buildout scenarios, one using minimum stormwater collection (Connecticut EIA) and the second using maximum stormwater collection (Alley and Veenhuis EIA).

For the full build-out scenarios the percentage change in streamflow during moderate-flow and high-flow events is relatively small, whereas during low-flow periods, the percentage change is much more substantial (fig. 33). This pattern of change is because recharge to the groundwater was reduced and therefore surface runoff increased. This result suggests the potential for a compounding effect on water quality during low-flow periods because surface runoff is generally of lower quality than groundwater. Wastewater return flows, such as those from Heritage Village in
Southbury (averaging approximately $1.02 \mathrm{ft}^{3} / \mathrm{s}$ under existing conditions), may comprise as much as 20 percent of the flow in the Pomperaug River at the point of wastewater discharge during extreme low flows under the full build-out scenario and maximum diversions. Therefore, the combined effect of a lower percentage of groundwater runoff and increased wastewater return flows could have a large effect on instream water quality, such as increased temperatures and increased nitrogen concentrations. Additionally, population increases in non-sewered areas of the watershed will increase the number of septic systems, which could contribute to increases in nitrate loading and other water-quality changes to groundwater beneath and downgradient from the septic system (Starn and Brown, 2007). 

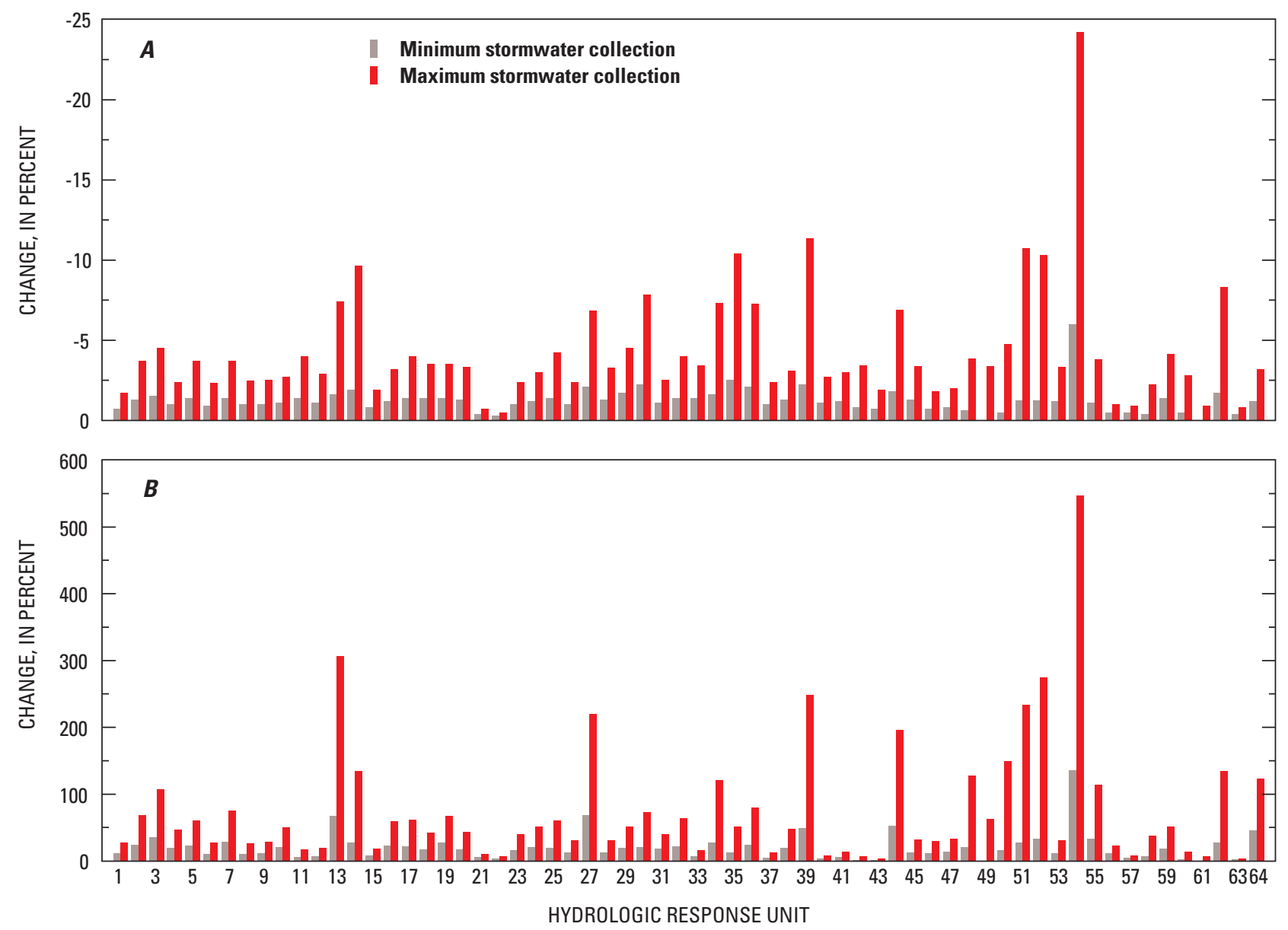

Figure 32. Average percentage change in $(A)$ recharge and $(B)$ surface runoff relative to existing conditions by hydrologic response unit, Pomperaug River watershed, Connecticut, for the full build-out scenarios, with maximum and minimum stormwater collection.

\section{Effects of Land Use and Groundwater Withdrawal on Recharge and Base Flow}

In the PRMS model, the key physical attributes of the land surface in each HRU that control runoff quantity and source are the (1) surficial geology, (2) soil type, (3) land cover (and in particular the amount of impervious surface), and (4) drainage density. The effect of these physical factors on groundwater recharge (and conversely surface runoff) was assessed in the model by multiple linear regression analysis. The simulated recharge was regressed against the above physical attributes for each HRU, and a simplified predictive equation was derived. Because the existing watershed has relatively low amounts of EIA, the hypothetical models developed for the management scenarios were used for this analysis because they offer a wider range of percent impervious surfaces across the watershed. The coefficients of the derived regression equation and their statistical significance are shown on table 17 .

The coefficients can be used to directly compare the magnitude of the effect of each attribute on the recharge estimate, and the t-statistic indicates how significant the attribute was in the prediction outcome. The most important attributes for predicting discharge are the coarse glacial stratified deposits, class D soils, the impervious surface, and, to a lesser degree, the drainage density. For the Pomperaug River watershed, the presence of glacial stratified deposits and high drainage density indicates high recharge and the presence of class D soils and impervious surfaces indicates reduced recharge. 

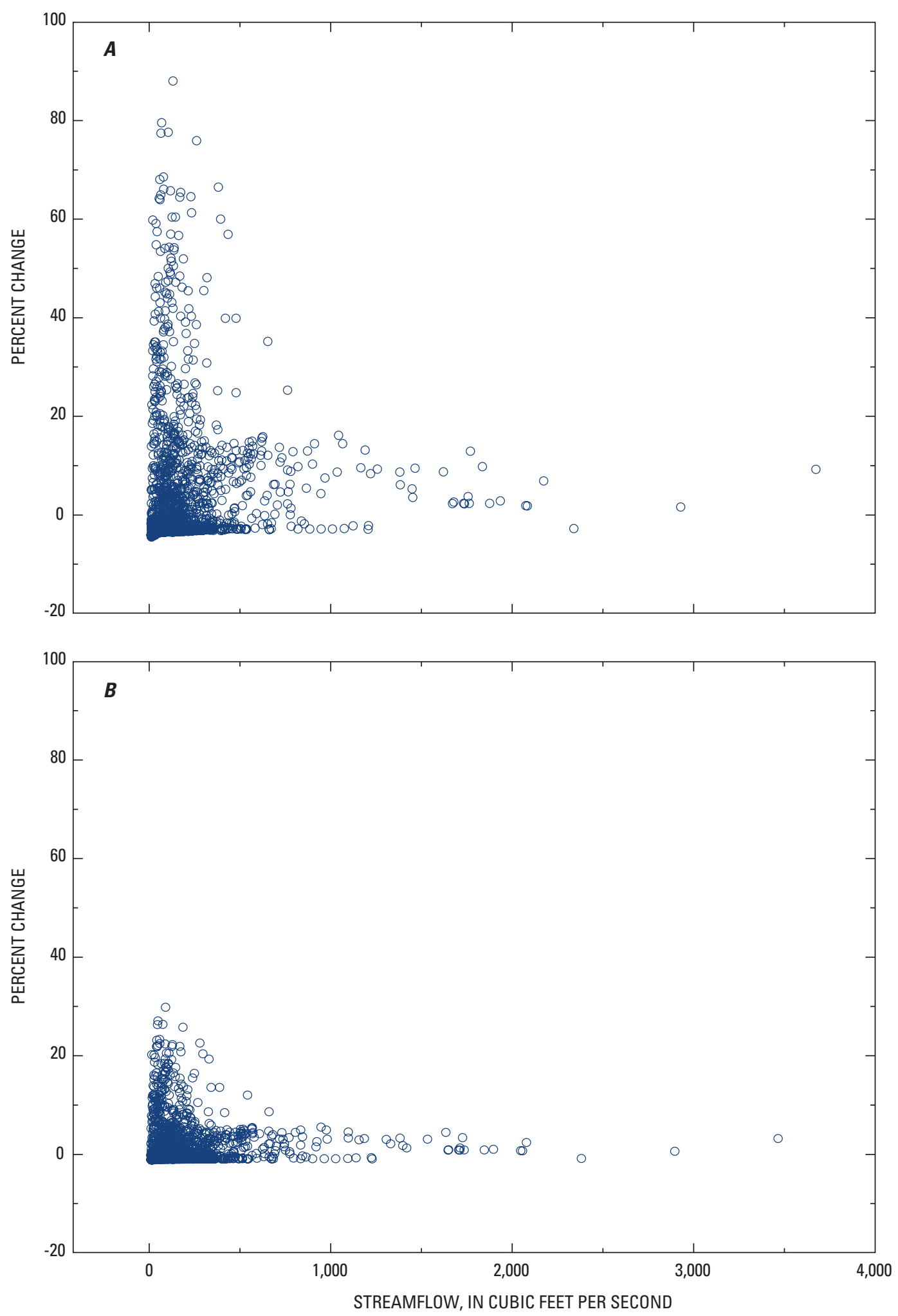

Figure 33. Percentage change in streamflow as a function of simulated streamflow for full build-out scenarios with $(A)$ maximum and $(B)$ minimum stormwater collection relative to existing conditions for the Pomperaug River at Southbury, Connecticut. 
Table 17. Regression statistics for multiple linear regression of physical attributes to predict recharge for the Pomperaug River watershed, Connecticut.

[Estimated recharge in inches per year; \%, percent]

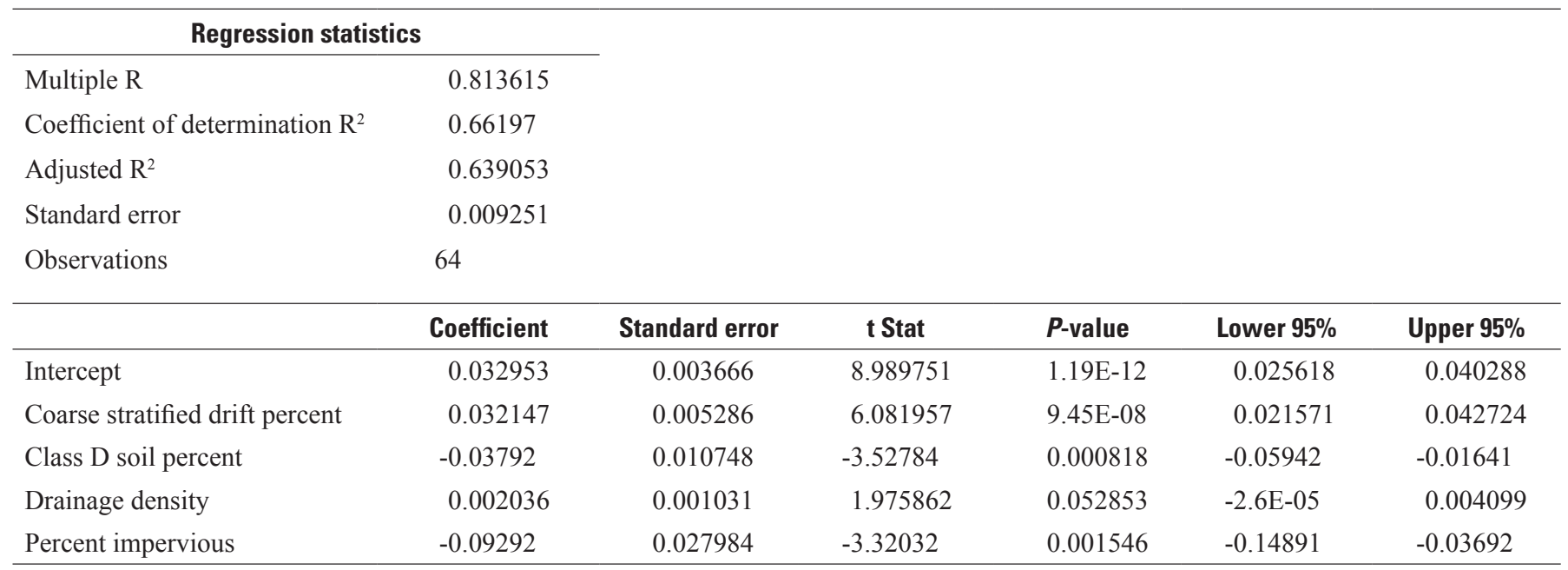

As previously discussed, vegetative land-cover type is also important in the amount of recharge. The monthly pattern and quantity of recharge to the groundwater as a function of all forest (undeveloped) and all grass (pasture and agriculture) by land-cover type are shown on figure 34 . The all-grass scenario shows an increase in recharge compared to the other scenarios, particularly during the summer months.

Two MODFLOW simulations were run to assess the effect of increased pumping on base flows. The first simulated the projected pumping rates to the year 2050, which were based on information provided from the water companies or estimated on the basis of expected population growth. The second simulated the pumping rate at the maximum registered diversion rate (including groundwater pumping and surfacewater withdrawals). The simulations were run assuming recharge from the full build-out land-use scenarios given the two different stormwater-collection scenarios. The pumping rates used in the simulations are shown on table 15 . The maximum pumping rate is assumed to be reached for each month of the year for the maximum pumping scenario, and smaller systems that do not require a permit are assumed to pump year round at the maximum rate allowable without a permit - 50,000 gal $/$ d.

MODFLOW-derived base-flow estimates for the Pomperaug River at the Southbury streamgage for full buildout scenarios that include (1) maximum stormwater collection and the estimated maximum pumping rates, and (2) maximum stormwater collection with projected pumping rates in 2050 are shown on figure 35 for the simulation period 1998 to 2006. In the Pomperaug River, the projected increases in groundwater pumping throughout the watershed from public supply systems results in about a 2 to $3 \mathrm{ft}^{3} / \mathrm{s}$ reduction in flow during the summer. This quantity is a substantial part of the overall streamflow during the low-flow period; however, it is somewhat less than the total groundwater withdrawals from the watershed. This indicates that storage within the aquifer attenuates the effects of pumping during periods of low flow, even though over the course of time, mass balance dictates that the water withdrawn by pumping must reduce discharge to streams by an equivalent amount. The effect of pumping throughout the watershed is cumulative in a downstream direction, and thus the magnitude of the effect would change depending on the ratio of cumulative flow to pumping in the downstream direction. The cumulative effect of individual home wells would also contribute to a reduction in base flow.

The simulation of the maximum full build-out scenario indicates that the duration of low-flow periods increases and low flows become lower with development. The change in the percentage of reaches that gain and lose water from (to) the groundwater and the percentage of reaches that are subject to going dry within the entire modeled areas over the course of the simulation period (1998-2006) is shown on table 18. Overall, the percentage of losing reaches does not change substantially; however, the number that go dry increases by 33 percent, assuming minimum stormwater collection; and by 67 percent, assuming maximum stormwater collection. In addition, the change in the number of days that South Brook is subject to going dry over the simulation period increases from 119 days for existing conditions to 123 days for the maximum full build-out scenario with increased pumping. These increases occur where development is projected to increase and where production wells are located. The length of time that the reaches are dry also increases with projected increases in impervious surface, exemplified by South Brook. These effects are associated primarily with change in land cover as opposed to groundwater withdrawals, because of the more widespread nature of the land-cover change. 

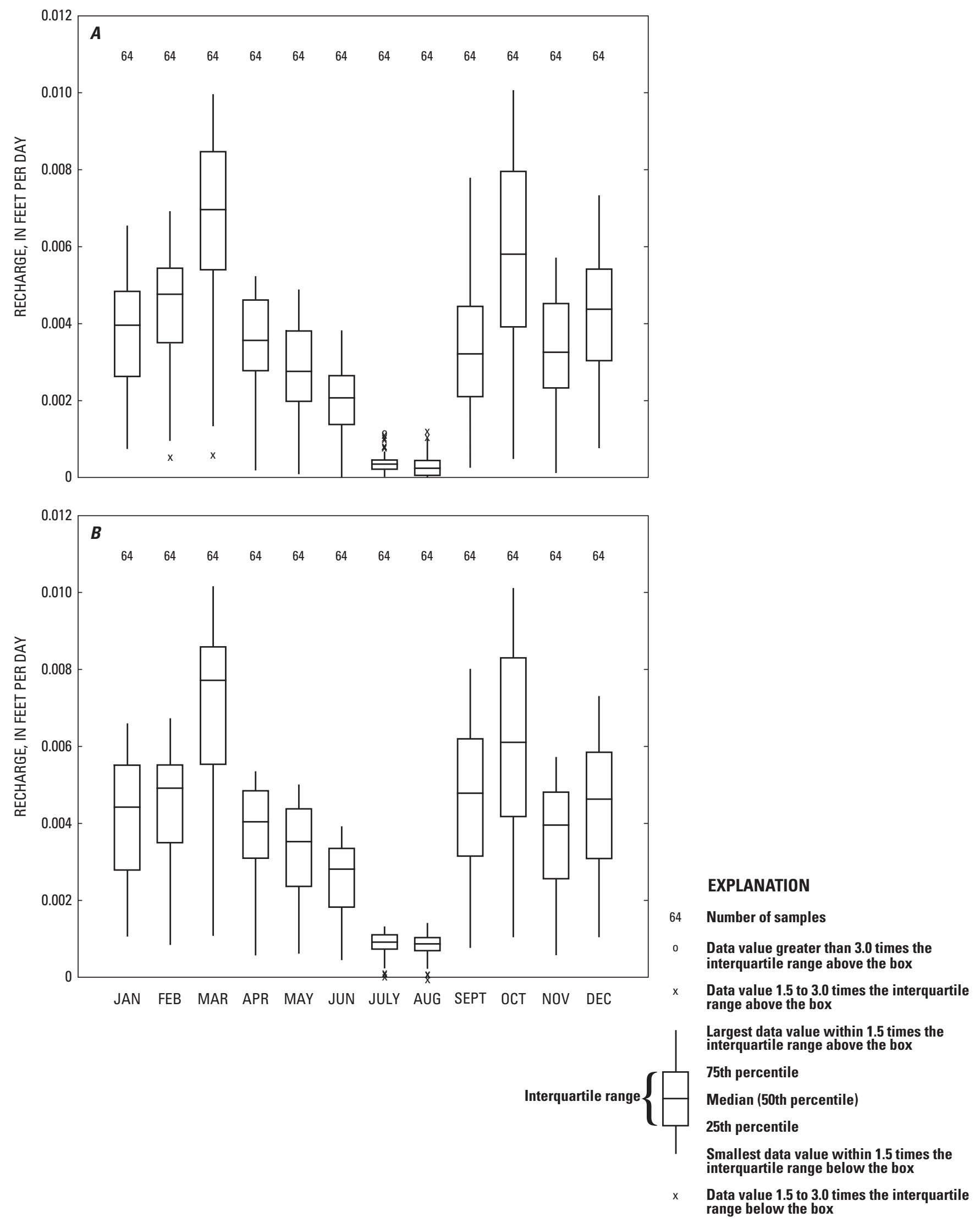

Figure 34. Average monthly groundwater recharge for uplands and valleys for ( $A$ ) all-forest and (B) all-grass scenarios, Pomperaug River watershed, Connecticut. 


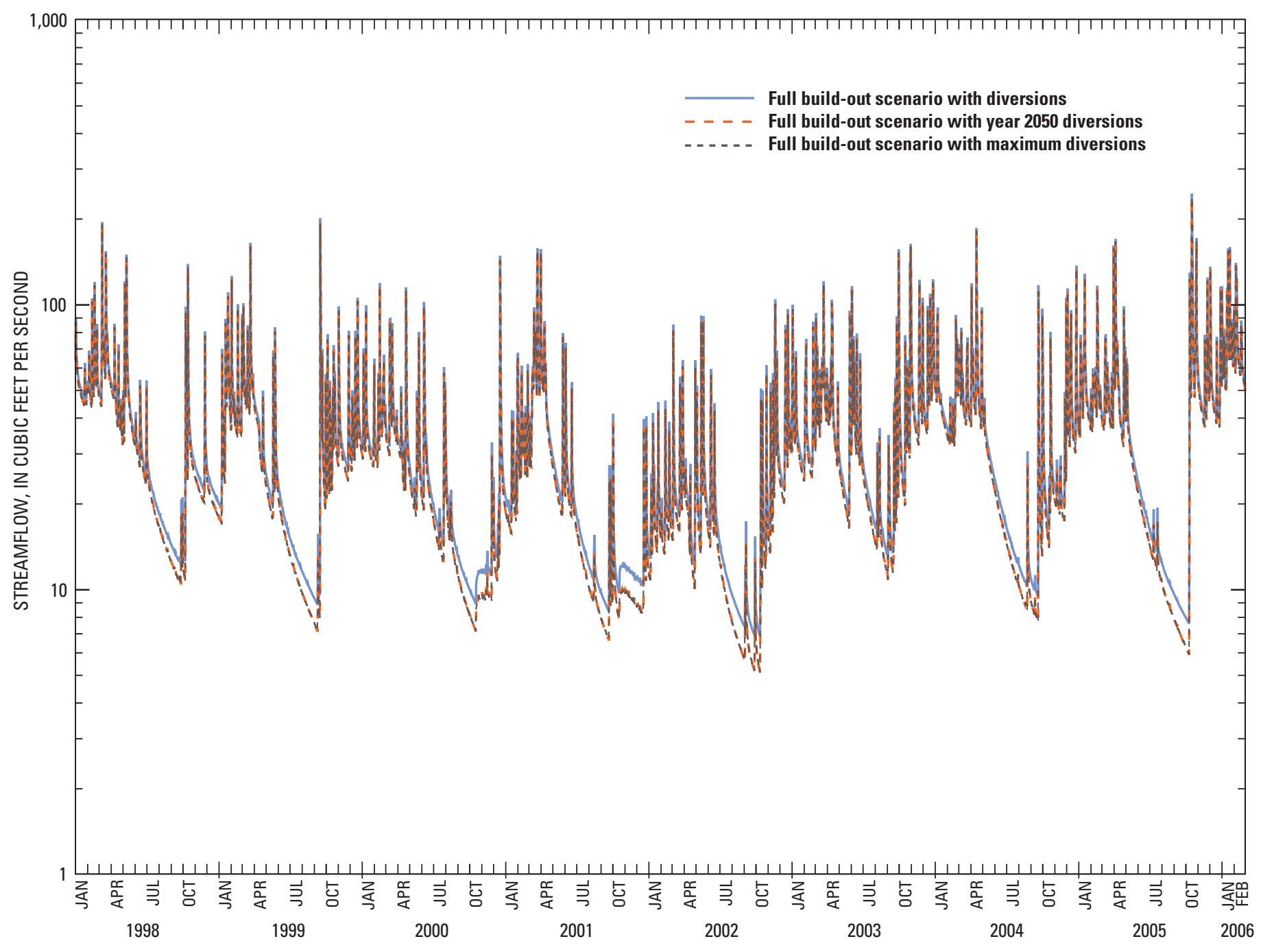

Figure 35. Effect of projected increases in pumping on base flow assuming full build-out land use, Pomperaug River watershed, Connecticut.

Table 18. Percentage of stream reaches in the Pomperaug River watershed, Connecticut, that can lose water to the groundwater, gain water from the groundwater, or can go dry for the full build-out scenarios compared to the existing scenario.

\begin{tabular}{|c|c|c|c|c|c|c|}
\hline \multirow{3}{*}{ Streamflow } & \multicolumn{6}{|c|}{ Percent of total stream reaches for all times in each scenario } \\
\hline & \multicolumn{2}{|c|}{ Existing conditions } & \multicolumn{2}{|c|}{$\begin{array}{l}\text { Full build-out with maximum } \\
\text { stormwater collection }\end{array}$} & \multicolumn{2}{|c|}{$\begin{array}{l}\text { Full build-out with maximum stormwater } \\
\text { collection and projected pumping in the year } 2050\end{array}$} \\
\hline & Uplands & Valley & Uplands & Valley & Uplands & Valley \\
\hline Losing & 12 & 10 & 11 & 10 & 11 & 11 \\
\hline Gaining & 39 & 25 & 38 & 26 & 39 & 26 \\
\hline Dry & 11 & 3 & 10 & 4 & 10 & 5 \\
\hline
\end{tabular}




\section{Limitations}

The PRMS model is based on physical relations between hydrologic variables and, as such, represents physical processes that control the water balance, streamflow, and hydrograph characteristics in time and in space. The model performs best for estimating monthly mean values and also performs well on the long-term daily mean values. However, simulation estimates of streamflow for any specific day may have considerable error and should be used with caution. The long-term daily streamflow statistics and the long-term representation of streamflow dynamics and seasonal fluxes are considered to be sufficiently accurate for understanding spatial distribution of hydrologic variables within the watershed, for assessing spatial and seasonal flow-regime characteristics of the watershed, and for assessing watershed and streamflow response to changes in land-cover conditions.

The base flow and recharge characteristics of the basin are considered to be accurately simulated by the model and can be used for assessing the effects of land-cover change on the temporal and spatial distribution of recharge and base flow to streams. Because the recharge and base-flow component of the hydrograph are accurately represented, the overall assessment of the source contributions to streamflow are considered sufficiently accurate to understand implications associated with changes in the source-water contribution to the streams within the watershed. The groundwater simulations using MODFLOW are considered representative of the spatial effects of recharge on groundwater discharge to streams and the effect of pumping on discharge to streams. The MODFLOW results are limited; they are not fully compatible quantitatively with PRMS because of differences in scale. Consequently, the MODLFOW results are considered sufficient for comparing relative temporal and spatial effects of land-cover and pumping changes on base flow to streams, but not necessarily the quantitative effects.

Water diversions are represented in the model in a simplified way and do not capture the full monthly and daily dynamics of the processes. In addition, flow augmentation from the Bronson-Lockwood Reservoir and artificial recharge to the Watertown Fire District well field are not explicitly modeled. Flow routing through the O\&G ponds is more dynamic than represented in the model, because the streambank that constrains the Pomperaug River is subject to erosion and reconstruction that alter the overflow conditions. Additionally, other channel and off-channel storage effects are not specifically incorporated into the model. As such, the routing of daily flows and accounting for groundwater diversions provides a general magnitude of the effect of these processes, but the data do not allow specific day-to-day or even month-to-month assessment of their effect on streamflow quantity and variability.

\section{Summary and Conclusions}

The Precipitation Runoff Modeling System (PRMS) parameterization strategy developed for the Pomperaug River watershed employs a minimum of calibration and optimization by establishing basic relations between the parameter value and physical characteristics of the individual hydrologic response units (HRUs) that can be obtained from general databases for Connecticut and quantified using geographic information system. This approach is important to successful application of PRMS because it provides a method to objectively optimize and calibrate the parameters for each HRU that would otherwise be unknown or unmeasurable. Additionally, it is important to have confidence that the parameterization process can be objectively repeated in other watersheds and would be relevant to past and future scenarios with changed or different physical watershed conditions. This latter condition is the basis for applying the model to simulate and evaluate the possible effects of various land-use and water-management strategies on streamflow and hydrology in the watershed.

Anthropogenic influences on streamflow in the watershed are important in maintaining low flows and reducing peak flows in the lower reach of the Pomperaug River. These influences include overflow into the O\&G quarry ponds and releases from the Bronson-Lockwood Reservoir. The absence of the reservoir releases could substantially reduce low flows in the river, and changes in the overflow and release characteristics into and out of the O\&G ponds would change the highflow and low-flow characteristics of the Pomperaug River downstream of the ponds.

The PRMS simulations, for the 22-year record from 1976 to 1998 and the 7-year record from 1999 to 2005, exhibit accurate long-term water balance and runoff characteristics. Additionally, the spatial and temporal variability of runoff is accurately simulated. This result indicates that the xyz precipitation parameterization method can successfully distribute measured precipitation from different input data sets across the watershed and that evapotranspiration is also accurately simulated. Although the day-to-day runoff simulations are acceptable from the standpoint of the modeling objective, the simulated daily runoff may have considerable error compared to the observed daily runoff. These conclusions hold for each of the comparisons made at the three streamgages in the watershed, indicating that the model simulations provide reasonably accurate results across the watershed. Thus, the model simulations can provide accurate representations of the hydrologic conditions and flow regime, both temporally and spatially distributed, but must be used with caution when considering the simulated runoff for a particular day. The mean annual streamflow estimates over a 7-year period show an error of less than 5 percent; however, the mean streamflow estimate for any given year may have an error up to about 14 percent.

Model-fit statistics indicate that the long-term water balance and runoff simulations are sufficiently accurate for assessing the effects of land-use and water-use changes on 
streamflow and groundwater recharge. The dynamics of the groundwater system can generally be considered to operate on much longer time frames than the surface dynamics; thus daily error in the simulated recharge values are less important when evaluating the effects of watershed changes on the groundwater. Overall, groundwater discharge supplies 60 percent or more of the flow to the stream system and is the principle source of water to the river.

The groundwater simulations made using MODFLOW are comparable to the simpler representation of groundwater runoff in PRMS considering the daily and longer term groundwater base-flow quantity and timing. However, MODFLOW provided much greater spatial detail in the simulation of base-flow conditions, including the occurrence of dry reaches at many locations within the stream network. To achieve greater comparability to groundwater recession and extreme low flows, MODFLOW required the inclusion of additional localized evapotranspiration losses from the aquifer riparian zones. Because of this, MODFLOW did not preserve the water balance as simulated by PRMS; therefore, the quantitative results of the MODFLOW simulation must be used with caution. This result indicates the need for greater spatial detail in the recharge and evapotranspiration elements of PRMS so that localized hydrologic processes occurring in riparian zones that affect groundwater discharge to streams are more accurately simulated.

Base-flow simulations using MODFLOW show that many stream reaches lose water to the subsurface and act to recharge local aquifers in the watershed. Some of these reaches can go dry for short periods of time. The location of the losing reaches tends to be in areas near the transition from the uplands to the valley bottoms that are filled with coarse glacial stratified deposits.

Simulation of projected and hypothetical development in the watershed shows that streamflow changes from being dominated by groundwater to being dominated by surface runoff when the effective impervious area in an HRU is between 10 and 20 percent, depending on the manner in which stormwater is managed. This shift would likely result in substantial changes in water quality and instream habitat characteristics of the river. Increasing impervious surface area generally increases streamflow and at the same time reduces groundwater and subsurface-runoff components, thus causing a compounding effect on the percentage of the flow that is comprised of groundwater.

Base flow to streams is reduced by increased impervious surface and increased groundwater withdrawals. In the Pomperaug River watershed, considering current zoning regulations, increased groundwater withdrawals have the potential for causing greater overall reductions in flow compared to increased development and impervious surfaces. Additionally, on the basis of the simulations, the projected increase in groundwater withdrawals and development across the watershed will increase the number of stream reaches experiencing dry conditions and the duration of these dry periods. The simulated increase in the duration and extent of dry stream reaches, however, appears to be related more to the general increase in impervious surface than to increased pumping, primarily because of the limited extent and number of large groundwater withdrawals in the watershed.

Conversion of land from forest or developed land cover to pasture or agricultural land (the all-grass scenario) increases groundwater recharge and discharge to streams, while at the same time increasing overall streamflow (the opposite effect as increased impervious surface). This increase in streamflow occurs because of a reduction in evapotranspiration. The allgrass scenario assumes no reduction in infiltration of precipitation, which may be representative of agricultural land but cannot be considered to be representative of lawns, which would be expected to be more compacted. These results indicate that preservation of agricultural land and pasture can provide hydrologic benefit with regard to recharge potential. As water use increases along with development and increasing population, the risk to instream habitat conditions that are dependent on flow volume is compounded. Additionally, there is a higher risk to flow reduction if registered diversions are used during these periods. The results indicate that if all registered diversions are used during periods of low flow, there is an increased risk that parts of the river system will experience extreme low flows below tolerable levels or possibly dry streambeds.

Because groundwater is the principle source of water to the river system, increased groundwater pumping and factors affecting recharge quantity and quality are important to the river health. Groundwater pumping will become a greater issue in the future, and development projections that are based on current zoning indicate that land-use change in the lower Pomperaug River watershed will reduce recharge and base flow to the lower reach of the river.

\section{Acknowledgments}

The authors would like to thank the members of the PRWC, especially Marc Taylor, Lawrence Pond, Laurie Giannotti, Cris Schaefer, Edward Edelson, and Donna Lesch, for their input and assistance with data collection and analysis. The authors would also like to thank Ken Ferroni of O\&G Industries for his cooperation with the study and Virginia Mason and Glenda Prentiss of the Naugatuck Valley Council of Governments for their input and development of projected full build-out land use and impervious surface area in the watershed. The authors appreciate the expertise and input provided by Phil Zarriello, Ed Koerkle, Steve Garabedian, and Paul Barlow of the U.S. Geological Survey for their technical reviews of the study. Also, the authors would like to thank George Leavesley, Lauren Hay, Steve Markstrom, and Roland Viger for their invaluable assistance with the PRMS model application. 


\section{References Cited}

Alley, W.M., and Veenhuis, J.E., 1983, Effective impervious area in urban runoff modeling: Journal of Hydraulic Engineering, v. 109, no. 2, p. 313-319.

Coon, W.F., and Johnson, M.S., 2005, Effect of land-use change and stormwater-detention basins on flooding and nonpoint-source pollution, in Irondequoit Creek basin, Monroe and Ontario Counties, New York-Application of a precipitation-runoff model: U.S. Geological Survey Scientific Investigations Report 2005-5070, 67 p.

DeSimone, L.A., 2004, Simulation of groundwater flow and evaluation of water-management alternatives in the Assabet River Watershed eastern Massachusetts: U.S. Geological Survey Scientific Investigations Report 2004-5119, 133 p.

Dingman, S.L., 2002, Physical hydrology: Long Grove, Ill., Waveland Press, Inc., p. 424-431.

Grady, S.J., and Weaver, M.F., 1988, Preliminary appraisal of the effects of land use on water quality in stratified-drift aquifers in Connecticut: U.S. Geological Survey WaterResources Investigations Report 87-4005, 41 p.

Halford, K.J., and Mayer, G.C., 2000, Problems associated with estimating ground-water discharge and recharge from stream discharge records: Ground Water, v. 38, no. 3, p. $331-342$.

Harbaugh, A.W., Banta, E.R., Hill, M.C., and McDonald, M.G., 2000, MODFLOW-2000, the U.S. Geological Survey modular ground-water model - User guide to modularization concepts and the ground-water flow process: U.S. Geological Survey Open-File Report 00-92, 121 p.

Hay, L.E., and McCabe, G.J., 2002, Spatial variability in water-balance model performance in the conterminous United States: Journal of the American Water Resources Association, v. 38, no. 3, p. 847-860.

Hay, L.E., Wilby, R.L., and Leavesley, G.H., 2000, A comparison of delta change and downscaled GCM scenarios for three mountainous watersheds in the United States: Journal of the American Water Resources Association, v. 36, no. 2, p. 387-397.

Hill, M.C., Banta, E.R., Harbaugh, A.W., and Anderman, E.R., 2000, MODFLOW-2000, the U.S. Geological Survey modular ground-water model-User guide to the observation, sensitivity, and parameter-estimation processes and three post-processing programs: U.S. Geological Survey Open-File Report 00-184, 209 p.
Kontis, A.L., Randall, A.D., and Mazzaferro, D.L., 2004, Regional hydrology and simulation of flow of glacial stratified aquifers in the glaciated northeastern United States: U.S. Geological Survey Professional Paper 1415-C, 156 p.

Leavesley, G.H., Restrepo, P.J., Markstrom, S.L., Dixon, M., and Stannard, L.G., 1996, The modular modeling system (MMS) —Users manual: U.S. Geological Survey Open-File Report 96-151, 142 p.

Leopold, L.B., Wolman, M.G., and Miller, J.P., 1964, Fluvial processes in geomorphology: New York, W.H. Freeman, $522 \mathrm{p}$.

Lyford, F.P., Carlson, C.S., Brown, C.J., and Starn, J.J., 2007, Hydrogeologic setting and ground-water flow simulation of the Pomperaug River Basin Regional Study Area, Connecticut, in Paschke, S.S., ed., Hydrogeologic settings and ground-water flow simulations for regional studies of the transport of anthropogenic and natural contaminants to public-supply wells - Studies begun in 2001: U.S. Geological Survey Professional Paper 1737-A, pp. 6-1-6-26.

Maidment, D.R., ed., 1993, Handbook of hydrology: New York, McGraw Hill, p. 10.7-10.8.

Mazzaferro, D.L., 1986a, Depth to bedrock, depth to the water table, and classification of unconsolidated materials above the water table in stratified-drift areas of part of the Pomperaug River Valley, Southbury and Woodbury, Connecticut: U.S. Geological Survey Miscellaneous Investigations Map I-1690, 1 sheet.

Mazzaferro, D.L., 1986b, Groundwater availability and water quality at Southbury and Woodbury, Connecticut: U.S. Geological Survey Water-Resources Investigations Report 84-4221, 105 p.

Meinzer, O.E., and Stearns, N.D., 1929, A study of groundwater in the Pomperaug River watershed, Connecticut with special reference to intake and discharge: U.S. Geological Survey Water-Supply Paper 597-B, p. 73-146.

Miller, D.R., Warner, G.S., Ogden, F.L., and DeGaetano, A.T., 2002, Precipitation in Connecticut: Storrs, Conn., Connecticut Institute of Water Resources, University of Connecticut, $66 \mathrm{p}$.

Nash, J.E., and Sutcliffe, J.V., 1970, River flow forecasting through models; Part I, A discussion of principals: Journal of Hydrology, v. 10, p. 282-290.

National Climatic Data Center, National Weather Service, 2002, Climatological data for New England: National Oceanic and Atmospheric Administration.

Northeast Regional Climate Center, 2006, Climod data access: Ithaca, N.Y., Cornell University, accessed February 28, 2006, at http://www.nrcc.cornell.edu/page_climod.html. 
Parasiewicz, Piotr, Legros, Jeffrey, Rogers, Joseph, and Wirth, Miira, 2007, Assessment and restoration of instream habitat for the Pomperaug, Nonnewaug and Weekeepeemee Rivers of Connecticut: Amherst, Mass., University of Massachusetts Northeast Instream Habitat Program, 103 p.

Pomperaug River Watershed Coalition, Inc., 2001, Pomperaug River state of the watershed report: Southbury, Conn., $47 \mathrm{p}$. plus appendixes.

Prisloe, M., Wilson, E.H., and Arnold, Chester, 2002, Populations-calibrated land-cover-specific impervious surface coefficients for Connecticut-Final Report Task \#6: Haddam, Conn., University of Connecticut Middlesex County Extension Center, 20 p.

Prudic, D.E., 1989, Documentation of a computer program to simulate stream-aquifer relations using a modular, finitedifference, groundwater flow model: U.S. Geological Survey Open-File Report 88-729, 113 p.

Risley, J.C., 1994, Use of a precipitation-runoff model for simulating effects of forest management on streamflow in 11 small drainage watersheds, Oregon Coast Range: U.S. Geological Survey Water-Resources Investigations Report 93-4181, 61 p.

Rosenbrock, H.H., 1960, An automatic method for finding the greatest or least value of a function: Computer Journal, v. 3 , p. $175-184$.

Rutledge, A.T., 1993, Computer programs for describing the recession of groundwater discharge and for estimating mean groundwater recharge and discharge from streamflow record: U.S. Geological Survey Water-Resources Investigations Report 93-4121, 45 p.

Rutledge, A.T., 1998, Computer programs for describing the recession of groundwater discharge and for estimating mean groundwater recharge and discharge from streamflow records-Update: U.S. Geological Survey Water-Resources Investigations Report 98-4148, 43 p.

Solley, W.B., Pierce, R.R., and Perlman, H.A., 1998, Estimated use of water in the United States in 1995: U.S. Geological Survey Circular 1200, 71 p.
Starn, J.J., and Brown, C.J., 2007, Simulations of groundwater flow and residence time near Woodbury, Connecticut: U.S. Geological Survey Scientific Investigations Report 2007-5210, 45 p.

Starn, J.J., Stone, J.R., and Mullaney, J.R., 2000, Delineation and analysis of uncertainty of contributing areas to wells at the Southbury Training School, Southbury, Connecticut: U.S. Geological Survey Water-Resources Investigations Report 00-4158, 54 p.

Sutherland, R.C., 2000, Methods for estimating the effective impervious area of urban watersheds: Watershed Protection Techniques, v. 2, no. 1, p. 282-284.

U.S. Department of Agriculture, Natural Resources Conservation Service, 2004, Soil Survey Geographic (SSURGO) database for the State of Connecticut, accessed April 2004 at http://soildatamart.nrcs.usda.gov.

Viger, R.J., Markstrom, S.L., and Leavesley, G.H., 1998, The GIS weasel-An interface for the treatment of spatial information used in watershed modeling and water resource management: Proceedings of First Federal Interagency Hydrologic Modeling Conference, April 19-29, 1998, Las Vegas, Nev., v. 2, chap. 7, p. 73-80.

Wilson, W.E., Burke, E.L., and Thomas, C.E., Jr., 1974, Water resources inventory of Connecticut, part 5, lower Housatonic River basin: Hartford, Conn., Connecticut Water Resources Bulletin 19, 79 p.

Zarriello, P.J., and Barlow, L.K., 2002, Measured and simulated runoff to the lower Charles River, Massachusetts, October 1999-September 2000: U.S. Geological Survey Water-Resources Investigations Report 2002-4129, 89 p.

Zarriello, P.J., and Ries, K.G., III, 2000, A precipitation-runoff model for analysis of the effects of water withdrawals on streamflow, Ipswich River watershed, Massachusetts: U.S. Geological Survey Water-Resources Investigations Report 2000-4029, 99 p. 
Table A1. GIS data and supporting parameter information for each HRU.

[HRU, hydrologic response unit; N1, HRU in Nonnewaug watershed; W1, HRU in Weekeepeemee watershed; PU1, HRU in Pomperaug watershed downstream of the

\begin{tabular}{|c|c|c|c|c|c|c|c|c|c|c|c|}
\hline HRU & $\begin{array}{l}\text { HRU } \\
\text { refer- } \\
\text { ence } \\
\text { number }\end{array}$ & $\begin{array}{c}\text { HRU } \\
\text { area } \\
\text { (acres) }\end{array}$ & $\begin{array}{c}\text { Mean } \\
\text { HRU slope } \\
\text { (percent) }\end{array}$ & $\begin{array}{l}\text { Median } \\
\text { HRU slope } \\
\text { (percent) }\end{array}$ & $\begin{array}{l}\text { Median } \\
\text { HRU } \\
\text { elevation } \\
\text { (meters) }\end{array}$ & $\begin{array}{l}\text { Root depth } \\
\text { (inches) }\end{array}$ & $\begin{array}{c}\text { Cover } \\
\text { density, } \\
\text { summer } \\
\text { (fraction) }\end{array}$ & $\begin{array}{c}\text { Cover } \\
\text { density, } \\
\text { winter } \\
\text { (fraction) }\end{array}$ & $\begin{array}{l}\text { X coor- } \\
\text { dinate, } \\
\text { Albers }\end{array}$ & $\begin{array}{l}\text { Y coor- } \\
\text { dinate, } \\
\text { Albers }\end{array}$ & $\begin{array}{l}\text { Fraction } \\
\text { coarse glacial } \\
\text { stratified } \\
\text { deposits } \\
\text { in HRU }\end{array}$ \\
\hline N1 & 1 & 877 & 6.9 & 6 & 322 & 23.1 & 0.46 & 0.21 & 1867107 & 2299038 & 0.000 \\
\hline N2 & 2 & 1,858 & 7.8 & 7 & 262 & 27.2 & 0.61 & 0.27 & 1867807 & 2295318 & 0.023 \\
\hline N3 & 3 & 452 & 9.3 & 9 & 274 & 23.0 & 0.41 & 0.25 & 1868787 & 2296118 & 0.024 \\
\hline N4 & 4 & 2,675 & 9.1 & 8 & 260 & 26.4 & 0.57 & 0.26 & 1870207 & 2295898 & 0.059 \\
\hline N5 & 5 & 284 & 9.9 & 9 & 218 & 30.6 & 0.75 & 0.31 & 1869207 & 2293218 & 0.076 \\
\hline N6 & 6 & 3,911 & 8.2 & 8 & 204 & 27.8 & 0.64 & 0.28 & 1872027 & 2291378 & 0.050 \\
\hline N7 & 7 & 1,231 & 10.1 & 9 & 173 & 30.0 & 0.72 & 0.30 & 1869767 & 2291358 & 0.081 \\
\hline N8 & 8 & 1,592 & 9.4 & 9 & 189 & 29.7 & 0.72 & 0.34 & 1868527 & 2290058 & 0.212 \\
\hline N9 & 9 & 763 & 9.4 & 8 & 160 & 33.0 & 0.87 & 0.41 & 1869607 & 2289638 & 0.036 \\
\hline N10 & 10 & 1,188 & 8.9 & 8 & 155 & 31.4 & 0.81 & 0.35 & 1871547 & 2287798 & 0.184 \\
\hline N11 & 11 & 1,382 & 11.2 & 11 & 163 & 30.4 & 0.81 & 0.41 & 1871327 & 2285978 & 0.152 \\
\hline N12 & 12 & 741 & 10.2 & 10 & 152 & 32.7 & 0.87 & 0.35 & 1868447 & 2287998 & 0.188 \\
\hline N13 & 13 & 76 & 6.4 & 6 & 78 & 18.5 & 0.26 & 0.11 & 1869347 & 2286678 & 0.803 \\
\hline N14 & 14 & 315 & 8.6 & 8 & 88 & 23.3 & 0.53 & 0.30 & 1869487 & 2285958 & 0.245 \\
\hline W1 & 15 & 1,053 & 9.0 & 8 & 303 & 28.1 & 0.71 & 0.30 & 1866147 & 2297998 & 0.014 \\
\hline W2 & 16 & 693 & 10.1 & 10 & 241 & 29.2 & 0.70 & 0.33 & 1865907 & 2295278 & 0.102 \\
\hline W3 & 17 & 1,107 & 8.9 & 8 & 215 & 29.7 & 0.73 & 0.35 & 1866847 & 2293078 & 0.084 \\
\hline W4 & 18 & 3,325 & 11.6 & 11 & 279 & 32.2 & 0.83 & 0.36 & 1864067 & 2295738 & 0.042 \\
\hline W5 & 19 & 794 & 9.8 & 9 & 206 & 29.3 & 0.69 & 0.28 & 1865387 & 2292138 & 0.060 \\
\hline W6 & 20 & 1,599 & 10.0 & 9 & 260 & 30.1 & 0.73 & 0.31 & 1864287 & 2291698 & 0.012 \\
\hline W7 & 21 & 1,875 & 13.1 & 12 & 236 & 32.6 & 0.85 & 0.36 & 1863027 & 2292298 & 0.036 \\
\hline W8 & 22 & 3,860 & 12.8 & 11 & 250 & 32.0 & 0.81 & 0.34 & 1862347 & 2289958 & 0.026 \\
\hline W9 & 23 & 540 & 11.5 & 12 & 181 & 33.3 & 0.90 & 0.46 & 1866947 & 2289998 & 0.100 \\
\hline W10 & 24 & 407 & 8.6 & 8 & 139 & 26.4 & 0.55 & 0.23 & 1865927 & 2290258 & 0.203 \\
\hline W11 & 25 & 276 & 14.2 & 13 & 145 & 30.7 & 0.79 & 0.34 & 1867007 & 2288518 & 0.247 \\
\hline W12 & 26 & 161 & 12.1 & 12 & 124 & 28.6 & 0.67 & 0.30 & 1866507 & 2288218 & 0.217 \\
\hline W13 & 27 & 284 & 12.6 & 12 & 121 & 31.5 & 0.80 & 0.34 & 1865907 & 2288118 & 0.417 \\
\hline W14 & 28 & 992 & 12.5 & 12 & 177 & 33.0 & 0.87 & 0.37 & 1865587 & 2287278 & 0.113 \\
\hline W15 & 29 & 186 & 11.5 & 11 & 97 & 31.7 & 0.81 & 0.43 & 1867747 & 2286938 & 0.426 \\
\hline W16 & 30 & 172 & 13.2 & 12 & 90 & 29.9 & 0.72 & 0.30 & 1868007 & 2287318 & 0.622 \\
\hline PU1 & 31 & 1,228 & 11.1 & 10 & 242 & 32.6 & 0.84 & 0.37 & 1865607 & 2285118 & 0.021 \\
\hline PU2 & 32 & 821 & 9.9 & 9 & 129 & 29.3 & 0.72 & 0.34 & 1867227 & 2285018 & 0.310 \\
\hline PU3 & 33 & 501 & 10.4 & 10 & 125 & 33.0 & 0.88 & 0.37 & 1867707 & 2285918 & 0.303 \\
\hline PU4 & 34 & 541 & 7.9 & 7 & 80 & 23.0 & 0.49 & 0.27 & 1869087 & 2284898 & 0.222 \\
\hline PU5 & 35 & 428 & 8.6 & 8 & 86 & 26.5 & 0.67 & 0.43 & 1870067 & 2283918 & 0.717 \\
\hline PU6 & 36 & 412 & 12.0 & 12 & 149 & 31.5 & 0.83 & 0.44 & 1870987 & 2284138 & 0.024 \\
\hline PU7 & 37 & 1,065 & 9.9 & 9 & 203 & 32.6 & 0.87 & 0.38 & 1872267 & 2283098 & 0.014 \\
\hline PU8 & 38 & 216 & 11.2 & 10 & 157 & 35.0 & 0.96 & 0.67 & 1871107 & 2282638 & 0.036 \\
\hline
\end{tabular}


confluence of the Nonnewaug and Weekeepeemee and upstream of the streamgage; PD1, HRU in Pomperaug watershed downstream of the streamgage]

\begin{tabular}{|c|c|c|c|c|c|c|c|c|c|}
\hline $\begin{array}{l}\text { Percent } \\
\text { imper- } \\
\text { vious } \\
\text { surface }\end{array}$ & $\begin{array}{c}\text { Decimal per- } \\
\text { cent effective } \\
\text { impervious } \\
\text { surface in } \\
\text { HRU }\end{array}$ & $\begin{array}{c}\text { Dominant } \\
\text { HRU } \\
\text { aspect } \\
\text { (degrees) }\end{array}$ & $\begin{array}{c}\text { Fraction } \\
\text { of open } \\
\text { water in } \\
\text { HRU }\end{array}$ & $\begin{array}{c}\text { Total length } \\
\text { of all } \\
\text { streams in } \\
\text { HRU } \\
\text { (miles) }\end{array}$ & $\begin{array}{c}\text { Characteristic } \\
\text { available soil } \\
\text { water capacity } \\
\text { for each HRU } \\
\text { (inch/inch) }\end{array}$ & $\begin{array}{c}\text { Fraction } \\
\text { type D } \\
\text { soils in } \\
\text { HRU }\end{array}$ & $\begin{array}{c}\text { Characteristic } \\
\text { summer rain } \\
\text { interception } \\
\text { for HRU } \\
\text { (inches) }\end{array}$ & $\begin{array}{l}\text { Characteristic } \\
\text { winter rain } \\
\text { interception } \\
\text { for HRU } \\
\text { (inches) }\end{array}$ & $\begin{array}{l}\text { Characteristic } \\
\text { snow inter- } \\
\text { ception for } \\
\text { HRU } \\
\text { (inches) }\end{array}$ \\
\hline 3.47 & 0.007 & 90 & 0.079 & 2.400 & 0.1139 & 0.03 & 0.041 & 0.019 & 0.011 \\
\hline 4.02 & 0.008 & 90 & 0.003 & 11.885 & 0.1074 & 0.02 & 0.047 & 0.021 & 0.015 \\
\hline 3.62 & 0.008 & 270 & 0.004 & 3.554 & 0.1109 & 0.01 & 0.043 & 0.024 & 0.017 \\
\hline 3.46 & 0.007 & 225 & 0.014 & 13.607 & 0.1080 & 0.03 & 0.046 & 0.021 & 0.014 \\
\hline 3.02 & 0.006 & 45 & 0.008 & 1.957 & 0.1119 & 0.00 & 0.048 & 0.02 & 0.015 \\
\hline 3.83 & 0.008 & 270 & 0.006 & 19.496 & 0.1076 & 0.08 & 0.046 & 0.021 & 0.015 \\
\hline 3.38 & 0.007 & 90 & 0.000 & 7.152 & 0.0971 & 0.08 & 0.048 & 0.021 & 0.016 \\
\hline 3.18 & 0.007 & 90 & 0.007 & 6.808 & 0.1093 & 0.07 & 0.047 & 0.022 & 0.02 \\
\hline 3.23 & 0.007 & 90 & 0.001 & 2.731 & 0.1074 & 0.10 & 0.048 & 0.023 & 0.025 \\
\hline 3.1 & 0.007 & 270 & 0.001 & 7.869 & 0.1022 & 0.26 & 0.049 & 0.022 & 0.02 \\
\hline 3.61 & 0.008 & 270 & 0.027 & 7.490 & 0.1022 & 0.21 & 0.045 & 0.023 & 0.028 \\
\hline 3.28 & 0.007 & 225 & 0.008 & 3.774 & 0.1044 & 0.17 & 0.048 & 0.021 & 0.018 \\
\hline 9.03 & 0.017 & 180 & 0.000 & 0.722 & 0.1017 & 0.00 & 0.032 & 0.015 & 0.007 \\
\hline 10.68 & 0.020 & 315 & 0.000 & 1.314 & 0.1098 & 0.07 & 0.037 & 0.022 & 0.026 \\
\hline 3.12 & 0.007 & 270 & 0.097 & 3.179 & 0.1118 & 0.05 & 0.043 & 0.019 & 0.016 \\
\hline 3.11 & 0.007 & 270 & 0.011 & 5.870 & 0.1183 & 0.01 & 0.047 & 0.022 & 0.019 \\
\hline 3.91 & 0.008 & 270 & 0.006 & 4.640 & 0.1130 & 0.02 & 0.047 & 0.023 & 0.022 \\
\hline 2.64 & 0.006 & 90 & 0.005 & 13.425 & 0.1217 & 0.03 & 0.047 & 0.021 & 0.019 \\
\hline 3 & 0.006 & 90 & 0.004 & 5.137 & 0.1130 & 0.01 & 0.048 & 0.02 & 0.013 \\
\hline 3.11 & 0.007 & 90 & 0.004 & 6.886 & 0.1204 & 0.04 & 0.049 & 0.021 & 0.016 \\
\hline 2.71 & 0.006 & 270 & 0.003 & 6.957 & 0.1171 & 0.03 & 0.049 & 0.021 & 0.019 \\
\hline 2.71 & 0.006 & 90 & 0.003 & 17.408 & 0.1193 & 0.11 & 0.049 & 0.021 & 0.017 \\
\hline 2.98 & 0.006 & 270 & 0.002 & 2.149 & 0.1103 & 0.01 & 0.048 & 0.025 & 0.032 \\
\hline 3.24 & 0.007 & 135 & 0.003 & 2.206 & 0.1072 & 0.04 & 0.047 & 0.021 & 0.011 \\
\hline 3.57 & 0.008 & 270 & 0.005 & 1.353 & 0.1128 & 0.04 & 0.044 & 0.021 & 0.019 \\
\hline 3.12 & 0.007 & 45 & 0.017 & 1.630 & 0.1190 & 0.02 & 0.049 & 0.021 & 0.016 \\
\hline 3.63 & 0.008 & 225 & 0.000 & 2.137 & 0.1144 & 0.01 & 0.049 & 0.021 & 0.018 \\
\hline 2.69 & 0.006 & 45 & 0.000 & 3.333 & 0.1162 & 0.05 & 0.049 & 0.022 & 0.02 \\
\hline 2.48 & 0.005 & 90 & 0.002 & 1.819 & 0.0890 & 0.28 & 0.048 & 0.028 & 0.03 \\
\hline 4.78 & 0.010 & 225 & 0.000 & 1.347 & 0.1107 & 0.17 & 0.047 & 0.021 & 0.017 \\
\hline 2.68 & 0.006 & 90 & 0.000 & 5.767 & 0.1117 & 0.03 & 0.049 & 0.022 & 0.021 \\
\hline 3.66 & 0.008 & 90 & 0.005 & 5.236 & 0.1130 & 0.03 & 0.047 & 0.023 & 0.021 \\
\hline 2.83 & 0.006 & 90 & 0.004 & 3.369 & 0.1085 & 0.22 & 0.047 & 0.022 & 0.02 \\
\hline 8.29 & 0.016 & 270 & 0.031 & 3.776 & 0.1071 & 0.03 & 0.042 & 0.022 & 0.021 \\
\hline 7.89 & 0.015 & 270 & 0.008 & 1.972 & 0.0965 & 0.29 & 0.041 & 0.025 & 0.037 \\
\hline 4.68 & 0.010 & 270 & 0.000 & 1.020 & 0.1131 & 0.07 & 0.047 & 0.024 & 0.031 \\
\hline 3.27 & 0.007 & 225 & 0.013 & 3.972 & 0.1236 & 0.19 & 0.048 & 0.022 & 0.021 \\
\hline 2.29 & 0.005 & 270 & 0.000 & 1.021 & 0.1040 & 0.03 & 0.049 & 0.035 & 0.058 \\
\hline
\end{tabular}


Table A1. GIS data and supporting parameter information for each HRU.-Continued

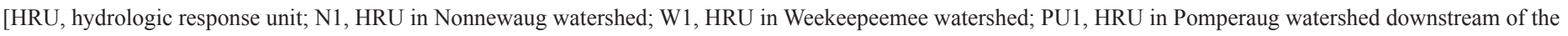

\begin{tabular}{|c|c|c|c|c|c|c|c|c|c|c|c|}
\hline HRU & $\begin{array}{l}\text { HRU } \\
\text { refer- } \\
\text { ence } \\
\text { number }\end{array}$ & $\begin{array}{c}\text { HRU } \\
\text { area } \\
\text { (acres) }\end{array}$ & $\begin{array}{c}\text { Mean } \\
\text { HRU slope } \\
\text { (percent) }\end{array}$ & $\begin{array}{l}\text { Median } \\
\text { HRU slope } \\
\text { (percent) }\end{array}$ & $\begin{array}{l}\text { Median } \\
\text { HRU } \\
\text { elevation } \\
\text { (meters) }\end{array}$ & $\begin{array}{l}\text { Root depth } \\
\text { (inches) }\end{array}$ & $\begin{array}{c}\text { Cover } \\
\text { density, } \\
\text { summer } \\
\text { (fraction) }\end{array}$ & $\begin{array}{c}\text { Cover } \\
\text { density, } \\
\text { winter } \\
\text { (fraction) }\end{array}$ & $\begin{array}{l}\text { X coor- } \\
\text { dinate, } \\
\text { Albers }\end{array}$ & $\begin{array}{l}\text { Y coor- } \\
\text { dinate, } \\
\text { Albers }\end{array}$ & $\begin{array}{l}\text { Fraction } \\
\text { coarse glacial } \\
\text { stratified } \\
\text { deposits } \\
\text { in HRU }\end{array}$ \\
\hline PU9 & 39 & 60 & 8.4 & 8 & 76 & 22.1 & 0.46 & 0.25 & 1870327 & 2282898 & 0.998 \\
\hline PU10 & 40 & 443 & 11.3 & 10 & 107 & 31.8 & 0.85 & 0.59 & 1869067 & 2283338 & 0.335 \\
\hline PU11 & 41 & 1,933 & 11.8 & 11 & 141 & 30.4 & 0.79 & 0.35 & 1867407 & 2282318 & 0.144 \\
\hline PU12 & 42 & 650 & 12.0 & 11 & 110 & 28.5 & 0.78 & 0.49 & 1868687 & 2280618 & 0.000 \\
\hline PU13 & 43 & 197 & 10.3 & 10 & 75 & 21.0 & 0.56 & 0.45 & 1869727 & 2281918 & 0.450 \\
\hline PU14 & 44 & 164 & 7.6 & 7 & 70 & 26.8 & 0.64 & 0.31 & 1870247 & 2281858 & 0.978 \\
\hline PU15 & 45 & 230 & 11.4 & 11 & 122 & 32.8 & 0.88 & 0.53 & 1870807 & 2281858 & 0.019 \\
\hline PU16 & 46 & 852 & 9.3 & 9 & 180 & 32.8 & 0.88 & 0.37 & 1871667 & 2280898 & 0.036 \\
\hline PU17 & 47 & 396 & 8.9 & 9 & 106 & 32.0 & 0.84 & 0.42 & 1870767 & 2279678 & 0.001 \\
\hline PU18 & 48 & 488 & 6.2 & 6 & 63 & 23.4 & 0.50 & 0.21 & 1869867 & 2279618 & 0.734 \\
\hline PU19 & 49 & 516 & 7.5 & 7 & 68 & 20.6 & 0.44 & 0.21 & 1869167 & 2279698 & 0.676 \\
\hline PU20 & 50 & 135 & 7.9 & 7 & 80 & 20.7 & 0.40 & 0.17 & 1869167 & 2278038 & 0.645 \\
\hline PU21 & 51 & 116 & 6.3 & 6 & 68 & 17.2 & 0.30 & 0.14 & 1869927 & 2277638 & 0.898 \\
\hline PU22 & 52 & 129 & 6.4 & 6 & 68 & 20.1 & 0.41 & 0.17 & 1870207 & 2278138 & 1.000 \\
\hline PU23 & 53 & 884 & 8.1 & 8 & 185 & 33.2 & 0.88 & 0.38 & 1872187 & 2279318 & 0.000 \\
\hline PU24 & 54 & 203 & 9.8 & 9 & 90 & 18.8 & 0.48 & 0.21 & 1871067 & 2278078 & 0.898 \\
\hline PU25 & 55 & 1,102 & 9.9 & 9 & 145 & 31.0 & 0.81 & 0.33 & 1872227 & 2277498 & 0.424 \\
\hline PD1 & 56 & 1,164 & 11.7 & 11 & 220 & 34.1 & 0.91 & 0.42 & 1865605 & 2281943 & 0.043 \\
\hline PD2 & 57 & 1,325 & 13.2 & 12 & 187 & 33.1 & 0.87 & 0.38 & 1865205 & 2280043 & 0.046 \\
\hline PD3 & 58 & 883 & 10.5 & 10 & 117 & 30.0 & 0.78 & 0.36 & 1867165 & 2278723 & 0.111 \\
\hline PD4 & 59 & 1,244 & 12.5 & 11 & 172 & 25.7 & 0.53 & 0.25 & 1865605 & 2277863 & 0.052 \\
\hline PD5 & 60 & 349 & 12.4 & 10 & 79 & 29.2 & 0.72 & 0.42 & 1867665 & 2276743 & 0.000 \\
\hline PD6 & 61 & 1,053 & 11.1 & 10 & 107 & 28.8 & 0.72 & 0.49 & 1868585 & 2277363 & 0.106 \\
\hline PD7 & 62 & 1,442 & 13.2 & 12 & 105 & 27.4 & 0.70 & 0.35 & 1869945 & 2275723 & 0.142 \\
\hline PD8 & 63 & 586 & 17.5 & 16 & 92 & 33.7 & 0.91 & 0.56 & 1867225 & 2274863 & 0.095 \\
\hline PD9 & 64 & 537 & 11.2 & 11 & 72 & 32.5 & 0.87 & 0.55 & 1867985 & 2274783 & 0.159 \\
\hline
\end{tabular}


confluence of the Nonnewaug and Weekeepeemee and upstream of the streamgage; PD1, HRU in Pomperaug watershed downstream of the streamgage]

\begin{tabular}{|c|c|c|c|c|c|c|c|c|c|}
\hline $\begin{array}{l}\text { Percent } \\
\text { imper- } \\
\text { vious } \\
\text { surface }\end{array}$ & $\begin{array}{l}\text { Decimal per- } \\
\text { cent effective } \\
\text { impervious } \\
\text { surface in } \\
\text { HRU }\end{array}$ & $\begin{array}{c}\text { Dominant } \\
\text { HRU } \\
\text { aspect } \\
\text { (degrees) }\end{array}$ & $\begin{array}{c}\text { Fraction } \\
\text { of open } \\
\text { water in } \\
\text { HRU }\end{array}$ & $\begin{array}{c}\text { Total length } \\
\text { of all } \\
\text { streams in } \\
\text { HRU } \\
\text { (miles) }\end{array}$ & $\begin{array}{c}\text { Characteristic } \\
\text { available soil } \\
\text { water capacity } \\
\text { for each HRU } \\
\text { (inch/inch) }\end{array}$ & $\begin{array}{c}\text { Fraction } \\
\text { type D } \\
\text { soils in } \\
\text { HRU }\end{array}$ & $\begin{array}{l}\text { Characteristic } \\
\text { summer rain } \\
\text { interception } \\
\text { for HRU } \\
\text { (inches) }\end{array}$ & $\begin{array}{l}\text { Characteristic } \\
\text { winter rain } \\
\text { interception } \\
\text { for HRU } \\
\text { (inches) }\end{array}$ & $\begin{array}{c}\text { Characteristic } \\
\text { snow inter- } \\
\text { ception for } \\
\text { HRU } \\
\text { (inches) }\end{array}$ \\
\hline 12.31 & 0.022 & 270 & 0.000 & 0.601 & 0.0919 & 0.01 & 0.036 & 0.019 & 0.023 \\
\hline 2.73 & 0.006 & 90 & 0.015 & 2.628 & 0.0978 & 0.34 & 0.048 & 0.032 & 0.05 \\
\hline 3.34 & 0.007 & 90 & 0.058 & 8.587 & 0.1175 & 0.17 & 0.045 & 0.021 & 0.021 \\
\hline 6.99 & 0.014 & 135 & 0.009 & 0.786 & 0.1015 & 0.53 & 0.041 & 0.027 & 0.041 \\
\hline 3.78 & 0.008 & 90 & 0.245 & 1.075 & 0.0985 & 0.39 & 0.03 & 0.023 & 0.042 \\
\hline 6.7 & 0.013 & 270 & 0.004 & 1.756 & 0.1129 & 0.00 & 0.048 & 0.022 & 0.02 \\
\hline 3.18 & 0.007 & 270 & 0.003 & 0.489 & 0.1082 & 0.07 & 0.049 & 0.029 & 0.041 \\
\hline 4.02 & 0.008 & 270 & 0.001 & 3.824 & 0.1178 & 0.03 & 0.049 & 0.021 & 0.021 \\
\hline 3.46 & 0.007 & 270 & 0.003 & 1.325 & 0.1165 & 0.03 & 0.049 & 0.024 & 0.028 \\
\hline 9.53 & 0.018 & 270 & 0.009 & 4.605 & 0.1186 & 0.00 & 0.042 & 0.018 & 0.012 \\
\hline 14.59 & 0.026 & 90 & 0.007 & 5.559 & 0.1046 & 0.02 & 0.038 & 0.018 & 0.017 \\
\hline 12.99 & 0.023 & 90 & 0.000 & 0.454 & 0.1168 & 0.00 & 0.044 & 0.02 & 0.012 \\
\hline 19.47 & 0.033 & 315 & 0.000 & 0.454 & 0.1016 & 0.00 & 0.036 & 0.018 & 0.015 \\
\hline 18.17 & 0.031 & 225 & 0.000 & 0.856 & 0.1072 & 0.00 & 0.036 & 0.018 & 0.015 \\
\hline 3.85 & 0.008 & 270 & 0.002 & 2.880 & 0.1165 & 0.08 & 0.048 & 0.021 & 0.022 \\
\hline 17.13 & 0.030 & 315 & 0.000 & 2.128 & 0.1063 & 0.00 & 0.029 & 0.013 & 0.02 \\
\hline 5.46 & 0.011 & 225 & 0.000 & 3.645 & 0.1124 & 0.01 & 0.047 & 0.02 & 0.019 \\
\hline 2.52 & 0.005 & 225 & 0.0000 & 4.050 & 0.1166 & 0.03 & 0.050 & 0.023 & 0.025 \\
\hline 2.71 & 0.006 & 90 & 0.0029 & 4.380 & 0.1130 & 0.14 & 0.049 & 0.023 & 0.022 \\
\hline 7.88 & 0.015 & 270 & 0.0086 & 3.563 & 0.1153 & 0.02 & 0.045 & 0.022 & 0.024 \\
\hline 3.56 & 0.008 & 90 & 0.0043 & 6.623 & 0.1089 & 0.11 & 0.048 & 0.022 & 0.014 \\
\hline 7.85 & 0.015 & 270 & 0.0026 & 1.243 & 0.1172 & 0.21 & 0.046 & 0.027 & 0.034 \\
\hline 8.61 & 0.017 & 90 & 0.0046 & 4.465 & 0.1148 & 0.27 & 0.045 & 0.030 & 0.044 \\
\hline 9.22 & 0.018 & 315 & 0.0011 & 5.550 & 0.1151 & 0.18 & 0.041 & 0.021 & 0.027 \\
\hline 2.12 & 0.005 & 90 & 0.0114 & 3.812 & 0.1119 & 0.22 & 0.049 & 0.030 & 0.044 \\
\hline 3.23 & 0.007 & 270 & 0.0137 & 3.408 & 0.1073 & 0.00 & 0.047 & 0.030 & 0.044 \\
\hline
\end{tabular}


Prepared by the Pembroke, West Trenton, and Lafayette Publishing Service Centers.

For more information concerning this report, contact:

Director

U.S. Geological Survey New Hampshire-Vermont Water Science Center 331 Commerce Way, Suite 2

Pembroke, NH 03275

dc_nh@usgs.gov

or visit our Web site at: http://nh.water.usgs.gov 
